Portland State University

PDXScholar

\title{
An Exploratory Analysis of Certain Characteristics of Policewomen: A Second Look
}

Harry Oliver White Jr.

Portland State University

Follow this and additional works at: https://pdxscholar.library.pdx.edu/open_access_etds Let us know how access to this document benefits you.

\section{Recommended Citation}

White, Harry Oliver Jr., "An Exploratory Analysis of Certain Characteristics of Policewomen: A Second Look" (1991). Dissertations and Theses. Paper 1213.

https://doi.org/10.15760/etd.1212

This Dissertation is brought to you for free and open access. It has been accepted for inclusion in Dissertations and Theses by an authorized administrator of PDXScholar. Please contact us if we can make this document more accessible: pdxscholar@pdx.edu. 
AN ABSTRACT OF THE DISSERTATION OF Harry Oliver White, Jr., for the Doctor of Philosophy in Urban Studies presented March 1, 1991.

Title: An Exploratory Analysis of Certain Characteristics of Policewomen: A Second Look.

\section{APPROVED BY MEMBERS OF THE THESIS COMMITTEE:}

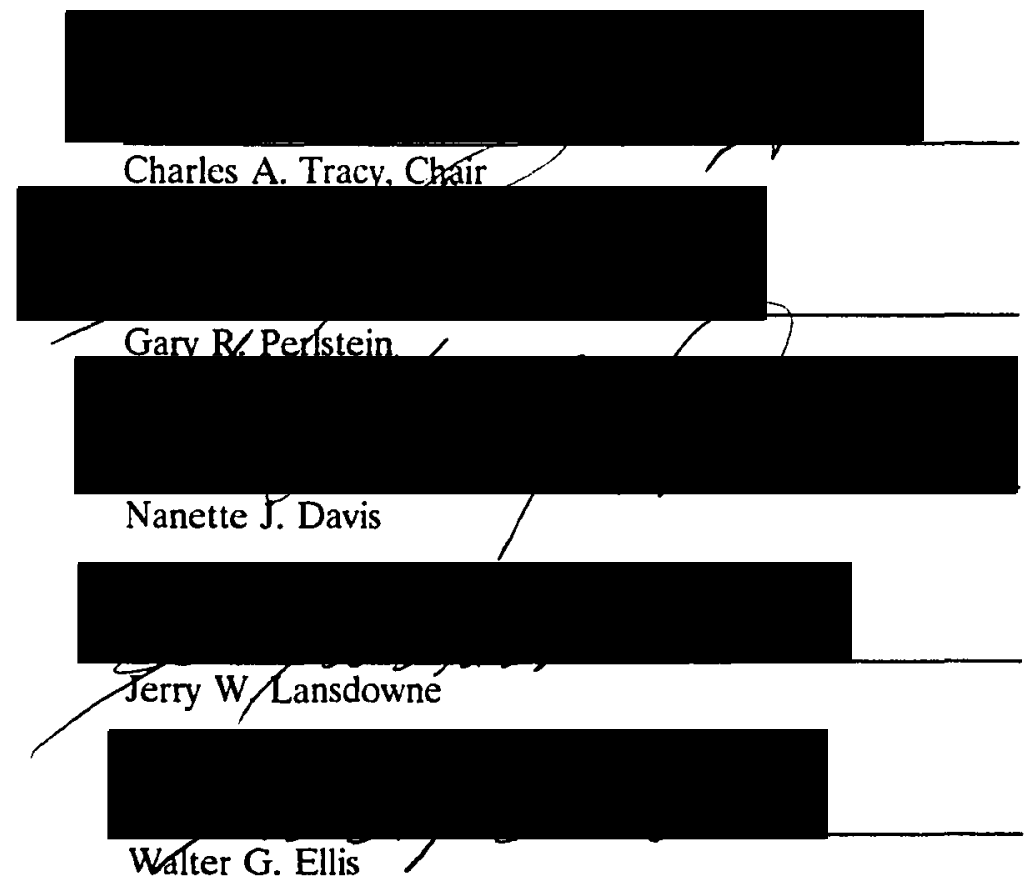

Female police officers are relatively new to the profession of law enforcement. Prior to 1968 , the very few who were employed by police agencies were not permitted to perform the full range of police duties. Subsequent to that time their number has increased so that today they account for approximately 8.3 percent of the total sworn police population. There have been numerou: studies which have attempted to identify 
the sociopsychological characteristics of male police officers. For example, Neiderhoffer reported in 1967 that male officers rate high in authoritarianism, anomia, job dissatisfaction, and choose police work for job security reasons. Very little research has been conducted about female police officers. The pioneering study of female police officers was conducted in 1971 by Dr. Gary R. Perlstein. He examined the extent to which the same characteristics studied by Neiderhoffer were found among female officers and reported consistently lower levels. Perlstein's study sample, however, was limited by the length of time his respondents could have performed line duties.

This dissertation was designed to partly replicate the Perlstein (1971) study in an effort to determine whether or not there have been changes in these characteristics among contemporary female police officers. Data were collected by administering a questionnaire to female police officers in eight of the fourteen police agencies surveyed by Perlstein (six declined to participate for unknown reasons), and to female police officers attending an annual professional conference. The total sample population was 784 , composed of all ranks performing all types of police work. The findings of this research appear to validate those reported by Perlstein. These findings should have significant impact on policies related to the recruiting, selection, and retention of all police officers. Equally important, was the strong implication that authoritarianism, anomia and job dissatisfaction are negatively associated with the problem-solving role associated with the emerging community-policing or new paradigm model of police organizations. The characteristics of female police officers may well become the standards against which future ideal police candidates should be evaluated. 


\section{AN EXPLORATORY ANALYSIS OF CERTAIN CHARACTERISTICS OF POLICEWOMEN: A SECOND LOOK}

by

HARRY OLIVER WHITE, JR.

A dissertation submitted in partial fulfillment of the requirements for the degree of

DOCTOR OF PHILOSOPHY

in

URBAN STUDIES

Portland State University

๑1991 


\section{TO THE OFFICE OF GRADUATE STUDIES:}

The members of the Committee approve the dissertation of Harry Oliver White, Jr., presented March 1, 1991.
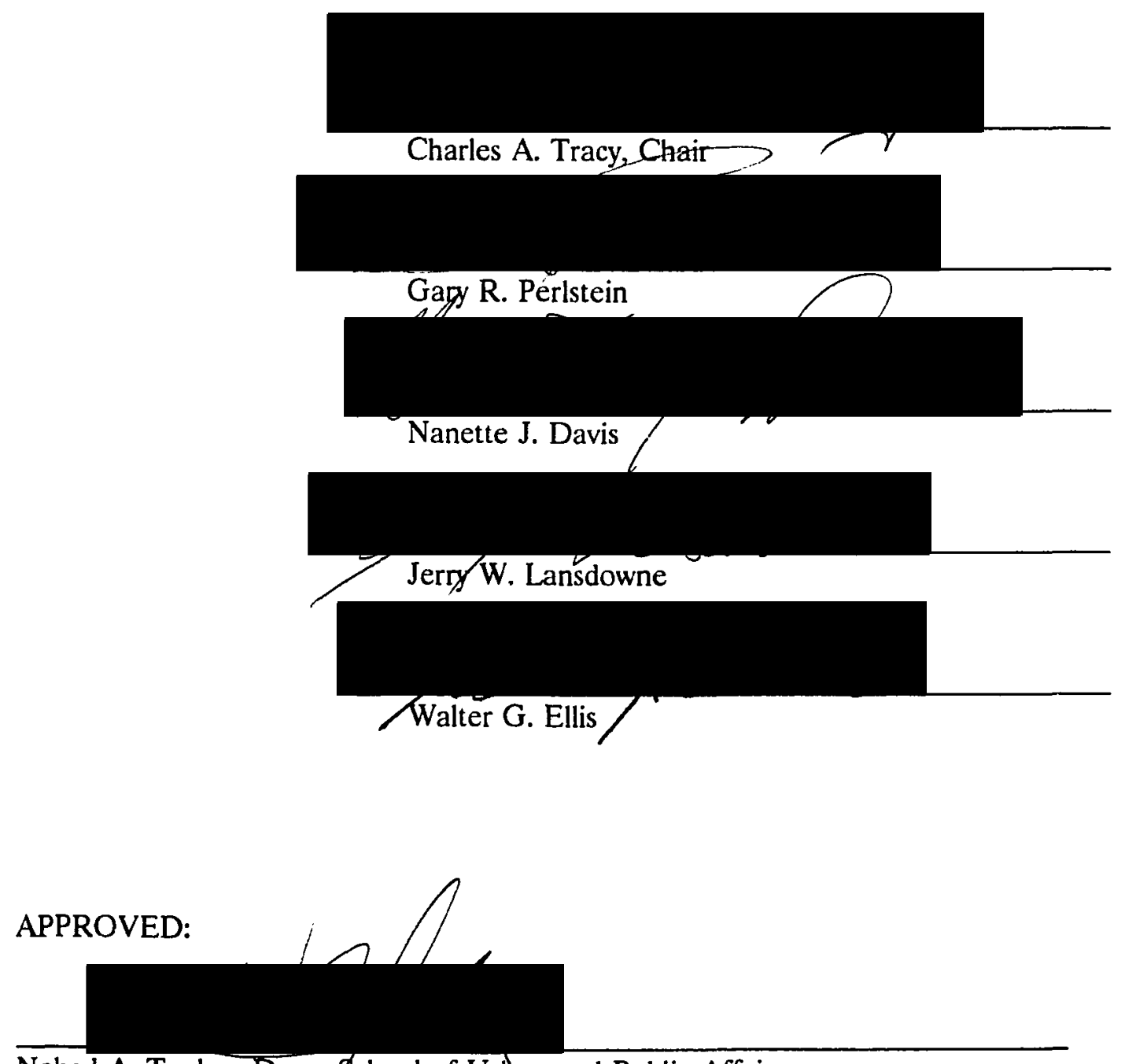

Nohad A. Toulan, Dean, School of Urban and Public Affairs

C. William Savery, Vice Provost for Graduate Studies and Research 


\section{DEDICATION}

I dedicate this project to my family who has supported me throughout my academic and professional careers.

To my parents Harry O. White, Sr., and N. Jean White, who passed away in 1988. It is with sadness that they were unable to witness this achievement.

To my children, Harry O. White, III, and Eleanor White-Nordness, I thank them for their patience and understanding because their father-student may not have devoted enough time to them during their childhood years.

To my wife Mary J. White, a police officer, without whose support and understanding this project would neither have been started nor completed. 


\section{ACKNOWLEDGEMENTS}

It is a most difficult task to identify and appropriately acknowledge everyone who has impacted the completion of this project. Dr. Charles A. Tracy and Dr. Gary R. Perlstein have been my teachers, mentors, and friends since my early college days, more than 20 years ago. Their support, guidance, and invaluable advice prepared me to undertake and complete this research project. I am indebted to them for my personal and professional achievements.

Dr. Jerry W. Lansdowne shared his expertise in the history and contemporary status of organizations. Dr. Walter G. Ellis nurtured and guided me through the literature on job satisfaction. I owe appreciation to Dr. Nanette J. Davis for helping me maintain the focus that women are competent, capable, and valuable members of the police profession.

This project would not have been possible without the assistance of the following enlightened police administrators who facilitated the gathering of data: Police Commissioner Edward J. Tilghman (Baltimore, MD), Colonel Lawrence E. Whalen (Cincinnati, OH), Chief Thomas R. Windham (Ft. Worth, TX), Chief Steven Bishop (Kansas City, MO), Chief Perry Anderson, Jr. (Miami, FL), Chief John T. Laux (Minneapolis, MN), Superintendent Warren G. Woodfork, Sr. (New Orleans, LA), Commissioner Willie L. Williams (Philadelphia, PA).

I owe special appreciation to all of the women who responded to my questionnaires, and to the International Association of Women Police whose dedication and professionalism are a credit to the police service. 


\section{TABLE OF CONTENTS}

PAGE

ACKNOWLEDGEMENTS $\ldots \ldots \ldots \ldots \ldots \ldots \ldots \ldots \ldots \ldots \ldots \ldots$ iii

LIST OF TABLES $\ldots \ldots \ldots \ldots \ldots \ldots \ldots \ldots \ldots \ldots \ldots \ldots \ldots \ldots \ldots \ldots \ldots \ldots$, vii

\section{CHAPTER}

I INTRODUCTION $\ldots \ldots \ldots \ldots \ldots \ldots \ldots \ldots \ldots \ldots \ldots \ldots$

Background $\ldots \ldots \ldots \ldots \ldots \ldots \ldots \ldots \ldots \ldots \ldots \ldots \ldots \ldots$

Problem Statement $\ldots \ldots \ldots \ldots \ldots \ldots \ldots \ldots \ldots \ldots$

Theoretical Framework ................ 14

II SELECTED REVIEW OF THE LITERATURE . . . . . . 16

Performance Standards . . . . . . . . . . . 16

Legal Precedents $\ldots \ldots \ldots \ldots \ldots \ldots \ldots \ldots \ldots$

Pre-Employment Testing $\ldots \ldots \ldots \ldots \ldots \ldots \ldots \ldots 21$

Employee Characteristics $\ldots \ldots \ldots \ldots \ldots \ldots \ldots \ldots$

III $\quad$ RESEARCH DESIGN $\ldots \ldots \ldots \ldots \ldots \ldots \ldots \ldots \ldots \ldots$

General Description ................ 34

Data Sources ...................... 34

Questionnaires .................. 36

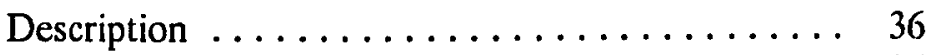

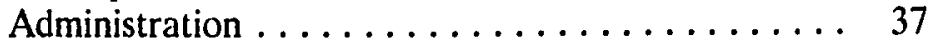

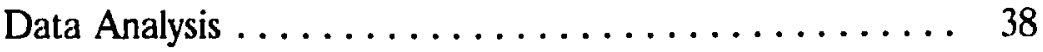


Unit of Analysis .................. 38

Variables.................... 39

Socioeconomic Status ............... 40

Hypothesis Testing $\ldots \ldots \ldots \ldots \ldots \ldots \ldots \ldots, 41$

Proposition $1 \ldots \ldots \ldots \ldots \ldots \ldots \ldots \ldots, 43$

Proposition $2 \ldots \ldots \ldots \ldots \ldots \ldots \ldots \ldots \ldots, 44$

Proposition $3 \ldots \ldots \ldots \ldots \ldots \ldots \ldots \ldots, 46$

Proposition $4 \ldots \ldots \ldots \ldots \ldots \ldots \ldots \ldots \ldots, 47$

Proposition $5 \ldots \ldots \ldots \ldots \ldots \ldots \ldots \ldots \ldots, 48$

Proposition $6 \ldots \ldots \ldots \ldots \ldots \ldots \ldots \ldots \ldots \ldots \ldots$

Proposition $7 \ldots \ldots \ldots \ldots \ldots \ldots \ldots \ldots, 45$

IV FINDINGS $\ldots \ldots \ldots \ldots \ldots \ldots \ldots \ldots \ldots \ldots \ldots \ldots \ldots$

Description of the Population ............... 50

Education $\ldots \ldots \ldots \ldots \ldots \ldots \ldots \ldots \ldots, 50$

Race $. \ldots \ldots \ldots \ldots \ldots \ldots \ldots \ldots \ldots, 51$

Religion $\ldots \ldots \ldots \ldots \ldots \ldots \ldots \ldots \ldots \ldots, 51$

Marital Status ................... 51

Age $\ldots \ldots \ldots \ldots \ldots \ldots \ldots \ldots \ldots, 52$

Tenure $. . \ldots \ldots \ldots \ldots \ldots \ldots \ldots \ldots, 53$

Rank ....................... 53

Work History $\ldots \ldots \ldots \ldots \ldots \ldots \ldots \ldots, 53$

Socioeconomic Status ................ 54

Reasons for Choosing Law Enforcement as a Profession .. 54

Proposition $1 \ldots \ldots \ldots \ldots \ldots \ldots \ldots \ldots \ldots$

Job Satisfaction and Morale $\ldots \ldots \ldots \ldots \ldots \ldots, 64$

Proposition $2 \ldots \ldots \ldots \ldots \ldots \ldots \ldots \ldots, 65$

Anomia $\ldots \ldots \ldots \ldots \ldots \ldots \ldots \ldots \ldots \ldots, 72$

Proposition $3 \ldots \ldots \ldots \ldots \ldots \ldots \ldots \ldots .74$

Authoritarianism $\ldots \ldots \ldots \ldots \ldots \ldots \ldots \ldots \ldots, 81$

Proposition $4 \ldots \ldots \ldots \ldots \ldots \ldots \ldots \ldots .63$

Interrelationships Among Scales $\ldots \ldots \ldots \ldots \ldots \ldots .90$ 
Proposition $5 \ldots \ldots \ldots \ldots \ldots \ldots \ldots \ldots \ldots \ldots$

Proposition $6 \ldots \ldots \ldots \ldots \ldots \ldots \ldots \ldots$

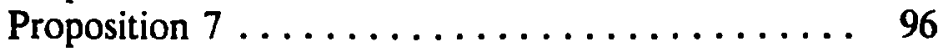

v CONCLUSIONS $\ldots \ldots \ldots \ldots \ldots \ldots \ldots \ldots \ldots$

Limitations $\ldots \ldots \ldots \ldots \ldots \ldots \ldots \ldots \ldots \ldots$

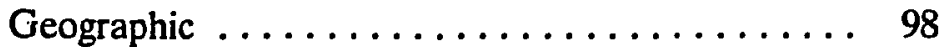

Gender ....................... 99

Representativeness ............... 99

Summary $\ldots \ldots \ldots \ldots \ldots \ldots \ldots \ldots \ldots \ldots$

Reasons for Choosing Law Enforcement . . . . . 99

Job Satisfaction and Morale . . . . . . . . . . . . 101

Anomia ..................... 102

Authoritarianism .................. 104

Differences Among Dependent Variables ......... 105

Policy Implications $\ldots \ldots \ldots \ldots \ldots \ldots \ldots \ldots \ldots \ldots$

Community-Oriented Policing . . . . . . . . 108

Recruiting ................... 110

Selection .................... 111

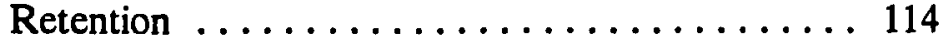

Future Research $\ldots \ldots \ldots \ldots \ldots \ldots \ldots \ldots$

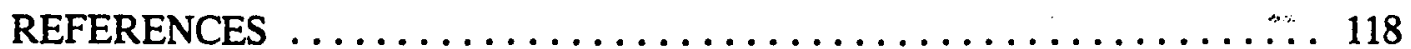

APPENDICES

A CHARACTERISTICS OF WOMEN IN POLICE SURVEY $\ldots . .139$

B STATISTICAL SUMMARY ................. 144

C SUMMARY STATISTICS ................ 147

D NONOCCUPATION CATEGORIES BY NUMBER AND

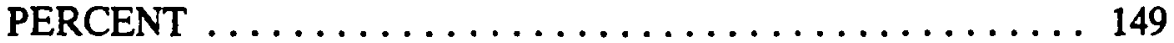

E CORRELATION COEFFICIENTS . . . . . . . . . . . 151 


\section{LIST OF TABLES}

I Research Population by Number and Percent .......... 35

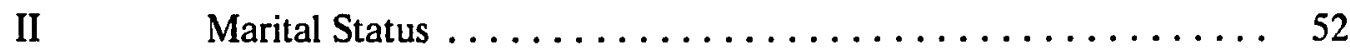

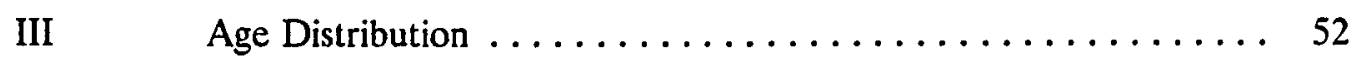

IV $\quad$ Rank $\ldots \ldots \ldots \ldots \ldots \ldots \ldots \ldots \ldots \ldots \ldots \ldots \ldots \ldots \ldots \ldots$

V Entry Age and Reason for Choosing Law Enforcement by Number

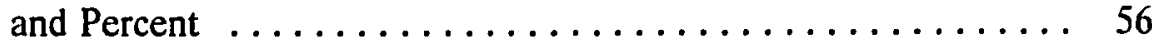

VI Religion and Reason for Choosing Law Enforcement by Number and Percent ............................ 57

VII Race and Reason for Choosing Law Enforcement by Number and Percent ............................. 58

VIII Years of Education and Reason for Choosing Law Enforcement by Number and Percent ...................... 59

IX Socioeconomic Status and Reason for Choosing Law Enforcement by Number and Percent $\ldots \ldots \ldots \ldots \ldots \ldots \ldots \ldots \ldots, 60$

X Entering Marital Status and Reason for Choosing Law Enforcement by Number and Percent ..................... 61

XI Rank and Reason for Choosing Law Enforcement by Number and Percent ............................ 62

XII College Major and Reason for Choosing Law Enforcement by Number

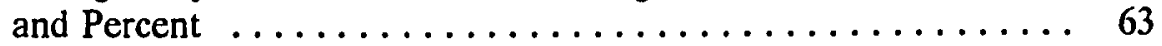

XIII Religion, and Job Satisfaction and Morale by Number and Percent ............................... 66

XIV Race, and Job Satisfaction and Morale by Number and Percent .. 67 
viii

XV Years of Education, and Job Satisfaction and Morale by Number and

Percent ............................. 68

XVI Marital Status, and Job Satisfaction and Morale by Number and

Percent . . . . . . . . . . . . . . . . . . . . . . . . . . . . . . . 69

XVII Type of Work, and Job Satisfaction and Morale by Number and Percent ......................... 70

XVIII College Major, and Job Satisfaction and Morale by Number and Percent ......................... 71

XIX Rank, and Job Satisfaction and Morale by Number and Percent . . 72

XX Religion and Degree of Anomia by Number and Percent ...... 75

XXI Race and Degree of Anomia by Number and Percent . . . . . . 76

XXII Years of Education and Degree of Anomia by Number and

Percent ............................. 77

XXIII Marital Status and Degree of Anomia by Number and Percent . . . 78

XXIV Type of Work and Degree of Anomia by Number and Percent . . . 79

XXV Rank and Degree of Anomia by Number and Percent $\ldots \ldots \ldots 80$

XXVI College Major and Degree of Anomia by Number and Percent . . . 81

XXVII Religion and Degree of Authoritarianism by Number and Percent . 84

XXVIII Race and Degree of Authoritarianism by Number and Percent ... 85

XXIX Years of Education and Degree of Authoritarianism by Number and

Percent ............................ 86

XXX Marital Status and Degree of Authoritarianism by Number and

Percent ............................. 87

XXXI Type of Work and Degree of Authoritarianism by Number and Percent .......................... 88

XXXII Rank and Degree of Authoritarianism by Number and Percent . . 89

XXXIII College Major and Degree of Authoritarianism by Number and Percent . . . . . . . . . . . . . . . . . . . . . . . . . 90 
XXXIV Degree of Anomia and Degree of Authoritarianism by Number and Percent ............................

XXXV Job Satisfaction and Morale, and Degree of Authoritarianism by Number and Percent ........................... 93

XXXVI Reason for Choosing Law Enforcement and Authoritarianism by Number and Percent ..................... 94

XXXVII Job Satisfaction and Morale, and Degree of Anomia by Number and Percent ........................... 95

XXXVIII Reason for Choosing Law Enforcement and Degree of Anomia by Number and Percent ...................... 96

XXXIX Reason for Choosing Law Enforcement, and Job Satisfaction and Morale by Number and Percent .................. 


\section{CHAPTER I}

\section{INTRODUCTION}

\section{BACKGROUND}

The topic of this study is the female police officer, one of whom has stated that her male counterparts expect women to "think like men, work like dogs, and act like ladies" (Martin, 1980, p. 219).

The above observation metaphorically describes the dilemmas faced by many female police officers. On the surface such similes may seem to be an exaggeration; however, the evidence suggests a significant gender role differentiation in the police profession (Sutton and Carlson, 1977; Koenig and Juni, 1981; Wexler and Logan, 1983; Davis, 1984; Jacobs, 1987; Steel and Lovrich, 1987; Greenan, 1987; Burke and Deszca, 1988). Sex role stereotyping suggests that some tasks are gender associated. The consequence of gender stereotyping is the manner in which it affects the perception of task performance. Hartmann, Griffeth, Miller, and Kinicki (1989) suggested that police work is male stereotyped, causing female success to be attributed to luck, while male success is attributed to skill. When this attitude permeates the organization, women who become police officers are predisposed to the potential of non-acceptance and possible failure merely because of gender.

Throughout the history of the police, females have been employed by police agencies. Their duties, however, were limited to positions requiring clerical skills or 
experience in dealing with women and children. Restricting females to specific support roles seems to suggest negative perceptions, based on gender, about their ability to perform the full range of law enforcement duties. Policing, as a predominantly male occupation, is bound by tradition, rather than empirical knowledge. Through the power of federal law, intervention by the courts, the leadership of enlightened police administrators, and the efforts of determined women, some of the traditions have been successfully challenged. However, there still appears to have been little change in attitudes and perceptions about female police officer competency (Bowersox, 1981).

In 1960, there were 785 women classified with the job title of policewoman, nationwide, none of whom performed line or patrol duties (Bell, 1982b). In 1968, Chief Winston Churchill, Indianapolis, Indiana, assigned two women to patrol duties, together in one patrol car. Male dispatchers were reluctant to assign calls to these officers, except when male occupied patrol vehicles were not available (Sherman, 1973; Weisheit, 1987). It was not until 1972 that the employment statistics of the police officers, compiled by the FBI, included the number of female police officers, which at the time was 1.4 percent $(3,157)$ (U.S. Department of Justice, 1972).

Milton (1978) suggested that in the next 100 years, the number of female police officers could reach 50 percent, with 30 percent of top administrators being women. Whether or not she is accurate, the growth in numbers is signalling an irreversible change in the gender composition of the police. The attitudes and perceptions of police administrators, male officers, and citizens about the law enforcement profession will also undergo some alterations. The actual percent of fully sworn female police officers in 1989 was small, only 8.3 percent, or 41,197 out of a total police officer population of 
455,156 (U.S. Department of Justice, 1990). As their numbers increase, they may be slowly overcoming some of the negative attitudes demonstrated by both their male counterparts and police administrators. In spite of reported high levels of competency, female police officers continue to be challenged because of the subjective perceptions that they are not physically or psychologically qualified for first-line duties.

A growing body of scholarly literature, however, contains significant objective findings about the performance of police officers. The data overwhelmingly supports the proposition that gender is not an important factor in determining a police officer's capabilities (Sherman, 1973, 1975; Davis, 1984; Weisheit, 1987; Balkin, 1988). The advent of females performing all line duties in police departments raises a question about how well they psychologically adapt to a male-dominated, nontraditional occupation characterized by a strict hierarchical organizational structure. Researchers have engaged in numerous studies of the characteristics of police officers and their work environment: sex roles (Doerfler and Kammer, 1986); predictions of success (Azen, Snibbe, and Montgomery, 1973); role styles (Wexler, 1985); MMPI (Carpenter and Raza, 1987; Saxe and Reiser, 1976); and paramilitary model (Franz and Jones, 1987). Studies have attempted to identify and describe differences and similarities among police officers to help explain their attitudes, personality traits, and competency levels. There is a significant amount of data as to the characteristics of police officers. These data, however, are insufficient in identifying the desired qualities of police officers. Assumptions about the characteristics of police officers are mostly based upon studies conducted after they have been selected and trained. What is not clear is how much of a police officer's working personality is developed after employment. In other words, are 
their attitudes and beliefs the result of socialization, or do they possess them prior to employment? Further, is there an identifiable personality difference between male and female police officers? The answers to these question are essential to the future of police service; but they are more important, perhaps, to females, in terms of their recruitment and retention. Without adequate research, unsubstantiated assumptions may be made which negatively impact the females' ability to gain employment in law enforcement. The evidence to date suggest females are well qualified (Armat, 1981; Sherman, 1975; and Bell, 1982b). Greenan (1987), reporting on a year-long study of 3,701 violent confrontations with citizens, suggested that females are far more emotionally stable, less aggressive, and are more likely to have a calming effect on potentially violent incidents. Other studies indicate that female police officers are as competent as males, and in some cases more so (Sherman, 1975; Armat, 1981; Triplett, 1976; and Deutsch and Leong, 1983). Competency and location appear to be confusing elements, i.e., what they are competent to perform seems clear; but where their performance should occur--in the police station or on the street--is controversial.

Social science interest in studying police officers has increased since the 1970 s. The recency of interest has not been for lack of need or importance. Rather, it appears to be due, in part, to the increased presence of women in this nontraditional maledominated profession. Prior to 1971 , female police officers were seldom the subjects of serious research. The small amount of research that has been conducted seems to be directed toward showing that females cannot perform police duties (Milton, 1972; Balkin, 1988). Consistently, studies tended to compare males and females, but were flawed by the absence of scientific data about the actual nature of police officer duties and 
performance standards. Research findings about male police officers' adaptation to the police environment appear to be clear and substantial. Therefore, if male attitudes and behavior are the accepted norm, and if females adapt differently, then the potential for dysfunction is high.

Police organization structure is based on the paramilitary model. There are certain behavioral characteristics associated with membership in paramilitary organizations, many of which are based upon assumptions. Authoritarianism, for example, may be inconsistent with the police service, but seems to be associated with their perceived mission. Military missions are dependent upon group action, where individualism may deter from the achievement of an objective. Police missions, on the other hand are highly dependent upon individual actions because police officers predominantly work alone. Therefore, highly centralized organizational structures tending to rely on authoritarianism appear to be incongruent with the police mission, and may result in reduced police effectiveness and efficiency.

Attempts at measuring effectiveness and efficiency continue to challenge police administrators and their organizations. The variables generally associated with such measurements appear to focus on the attributes of individuals. Kanter (1977b) suggested that concentration on the individual variable tends to obsolve the organization from responsibility when explaining performance behaviors. Most police services are generally reactive and encompass a myriad of social problem-solving tasks; which, interestingly, early police administrators used as a reason to first begin employing females. Those pioneering women were expected to take a proactive approach toward the safety and 
security of women and children, which was the reason for requiring special education and training (teaching, social work, nursing).

Less attention, however, has been given to the impact of organizational variables and how individuals function in a strictly structured environment. In order to understand the individual-organization relationship, the police mission needs to be identified. Based upon the types of services now being demanded, it could be argued that males have assumed the traditional female police officer role of helping. The vast majority of police calls for service are related to nonviolent social problems, rather than media-portrayed criminal violence (Sherman, 1973). Ironically, the acceptance of the female officer continues to be questioned in the traditional organization--even though there are no empirically supported findings in the literature which suggest, directly or indirectly, that women have any characteristics, even physical, that limit their abilities to perform police tasks (Sherman, 1973; Bell, 1982b; Charles, 1982; Wexler and Logan, 1983; and Lord, 1989).

Martin (1979), however, reported that "generally women aren't aggressive enough, but once you've been punched a couple of times, you learn to get the first punch in" ( $p$. 318). Martin's assertion is supported by Powell (1988) who suggests that women and men are equally aggressive--when provoked. The issue, however, is the degree of provocation is generally different, men requiring less. Balkin (1988) reported that members of the Amsterdam (Holland) Police complained that policewomen were of no significant help in a fight situation; however, they were equally critical if the women were aggressive. One of the characteristics of authoritarianism is aggressiveness. The extent to which aggressive behaviors are a necessary part of police work is debatable and unclear. 
Concomitant with the question about the performance of the female police officer are the problems associated with the psychological ramifications of their membership in a strict hierarchically structured male-dominated organization. The advent of females performing all line duties raises a question about how well they psychologically adapt to the organization. Persons who work in authoritarian bureaucratic organizations are referred to as suffering from the "bicyclist syndrome--one who bows his head above and kicks below" (Crosby, 1979, p. 217). Females are faced with the additional dilemma of integration into an organization which is structured to resist the type of change their membership represents. This is exemplified by entry level and performance standards based upon male physical and psychological attributes.

Fairchild (1987) described the police organization as, "fraternal, with emphasis on male values of dominance, use of force, assertion of authority and ... generally not hospitable to women" (p. 375). Fairchild's proposition is supported by Grennan (1987) who suggested that the view of most police executives is that females do not belong in the patrol function because of their lack of physical strength and inability to maintain an authoritarian presence when faced by challenges from the public.

Since the passage of the Civil Rights Act in 1964, there has been a growing body of literature pertaining to the entrance and participation of women in nontraditional occupations (Kanter, 1977a; Speizer, 1981; Bhatnagar, 1988; Powell, 1988; and Lunneborg, 1990). These authors, and others, have pointed out the problems associated with integration of women into male-dominated occupations. The discussions appear to be focused on individuals differences and organizational features. Female attributes and abilities are evaluated based upon those possessed by male incumbents. Those same 
males have developed and institutionalized the structural components of the organizations. The difficulty women face is finding a way to overcome the perception that they do not possess the physical and psychological attributes consistent with satisfactory performance. In addition, the structural barriers established by the organizations inhibit opportunities for women to maximize their potential. Regarding personal attributes, Kanter (1977b) offered that every statement made about what women feel or do can also be said about men. She continued by suggesting that structurally there are three issues which affect women: power, opportunity, and tokenism. So long as women are inhibited from gaining opportunity and power, and continue in token status, they will not be successful in overcoming barriers to job entry and full professional participation.

The issues appear to focus on three major points: (a) the bureaucratic organizational structure is believed to best serve the police in accomplishing their mission; (b) only certain types of persons are best qualified to function in a highly structured paramilitary environment; and (c) females do not have the abilities and qualifications to meet performance standards and expectations.

"The police must be stable, efficient, and organized along military lines" (Germann, Day, and Gallati, 1970, p. 54). This was the first tenet suggested by Sir Robert Peel, as the basis for formation of the London Metropolitan Police in 1829. Almost all modern police agencies are organized using the Peelian philosophy. The concept of stable police officers has, in recent years, been aggressively addressed through the adoption of various psychological and physical tests, and background investigation for police candidates. The vast majority of police organization and management literature 
is devoted to describing how police organizations are designed to function in a paramilitary structure (Whisenand and Ferguson, 1973; Garmire, 1982; Senna and Siegel, 1987; Schultz and Beckman, 1987; Bartollas and Jaeger, 1988). For the most part, contemporary organizational theorists have separated themselves from the classical theorists and their reliance on the Weberian model, in favor of a more humanistic approach to management and structure (Likert, 1961; Herzberg, 1972; Burke, 1982; Fordyce and Weil, 1987; McGregor, 1960).

An important discussion on behalf of the humanistic approach is presented by McGregor (1960) in The Human Side of Enterprise. His dichotomous theory suggests philosophical differences in management and structure which diametrically oppose one another. Theory $\mathrm{X}$ is characterized by the managerial assumption that humans dislike work and will go to any length to avoid it. Therefore, in order for the manager to achieve organizational goals, the employee must be threatened, coerced, and under absolute control. Theory $\mathrm{X}$ completely disregards all ideas of personal motivation to achieve goals, except for the use of salary.

Theory $\mathrm{Y}$, on the other hand, suggests that individuals are not motivated by extrinsic rewards, punishment, or threats. Rather, each person possesses intrinsic values associated with goal achievement which tend to satisfy their ego and self-actualized needs. Management goals should be directed toward integration of individual intrinsic values with organizational goals.

Other theorists from the humanistic school are in agreement with and expand on McGregor's (1960) theory (Likert, 1961; Bennis, 1966; and Herzberg, 1971). The basic thrust of their arguments is based upon the inefficiency and coerciveness of highly 
structured organizations, which results in dissatisfaction and negative psychological conditions among employees.

Since the 1960s, a new discipline, contrasting the classical theory of structure and management, has evolved under the label of organizational development (Burke, 1982). Its basic concept eliminates authoritarianism, and advocates decentralization and maximization of human potential. McGregor (1960) suggested that organizations functioning under autocratic leadership tend to be characterized by inefficiency and dependence. He reported that persons who become dependent are less satisfied because of their inability to exercise discretion and judgment.

Police organizations continue to rely on highly centralized control of most activities and individual behaviors. Auten (1985) reported that a survey of Illinois police departments revealed that 87 percent were structured along paramilitary lines and the respondents believed it to be the most effective system of management. Police organizations attempt to maintain authoritarian control through issuance of orders and rules. These directives are designed to remove as much discretion as possible on the part of the individual officer. Reliance on authority for all actions "encourages countermeasures, minimal performance, even open rebellion" (McGregor, 1960, p. 26). An example of this was offered by Auten (1985): "The typical patrol officer . . . spends as much time covering up his/her violations of the rules as in complying with them" (p. 126).

There is a current and growing trend toward a new paradigm which suggests a major philosophical change in the manner in which police services are delivered and may accelerate the acceptance of the female police officer. The new paradigm is labelled community-oriented or problem-solving policing (Skolnick and Bayley, 1988; Brown, 1989; 
Goldstein, 1990). Its major tenet is to emphasize the helping aspects of police work within a decentralized organizational structure. Police officers are expected to become involved in all aspects of the communities and neighborhoods they serve. The new concept is designed to address the total social problem as opposed to a partial enforcement approach--identification, arrest, and adjudication. Focusing on the individual offender is not believed to be solving the problem.

This change in paradigm will significantly alter police operational strategies and organizational structure. The traditional paramilitary structure, characterized by highly centralized control mechanisms, is reinforced by a military-type rank structure and chain of command. The philosophy upon which this hierarchical structure is based assumes that policework is reactive, a group effort, physical, and male dominated--features of the old paradigm. The emerging new paradigm, however, is represented by more proactive strategies, individual actions, less physical problem-solving, and gender neutrality--features of community policing. Lincoln (1985) identified characteristics associated with a paradigm, including the key ingredients for identifying change. She reported that a paradigm is based upon assumptions which establish a belief system. The hypotheses upon which assumptions rest, may or may not be based upon fact. There is a dichotomous relationship between old and new paradigm assumptions. In the delivery of police services this relationship exists in terrns of operational modes--reactive versus proactive. One such assumption of police administrators is that the most efficient means for the delivery of reactive police service is through a strict hierarchical organizational structure. 
The old paradigm is exemplified by the operational mode of early police departments. Officers reported to and worked in a static environment--the station house. Under this configuration it was assumed that police actions, behaviors, and decisions could be rationally controlled. Weick (1985), however, suggested that rationality is managerially based: if a decision or action is inconsistent with managerial philosophy it is not rational. Technological advances and population dispersion have challenged the ability of the police to maintain their reactive posture (e.g., the automobile and telecommunications). Because of these challenges, and increased demands for service, police actions are necessarily accomplished by officers independently, and away from the station house, which presents serious challenges to managerial control rationale.

Lincoln's (1985) discussion focused on the characteristics of change necessary for old to become new. Attendant to the philosophical changes are assumptions about the phenomena itself. As stated earlier, the foundation for police organizational structure is based on the Peelian model. The concept, and associated belief system, is designed for control and accountability of police officers in a rational manner. Under the old rulebased ideology, independent actions or thinking inconsistent with formal pronouncements are prohibited. Once assumptions change, consciously or unconsciously, a new paradigm is in the fomenting phase of change. A paradigmatic shift is gradual, rather than instantaneous, and carries assumptions and beliefs which must change before a new paradigm can be identified.

The evidence suggests that the assumptions supporting the old paradigm of policing are no longer valid. Therefore, it is necessary to provide data which alter these inaccurate assumptions in order to change belief systems of administrators, practitioners 
and their constituents. The operational changes dictated by the new paradigm bring into question the current practices of recruitment, selection, and retention of police officers. The traditional notion that requires a strict hierarchical structure, and recruits only those persons who possess characteristics associated with success in such an environment (authoritarian), may no longer be appropriate (if it ever was).

Perlstein's (1971) pioneer research clearly demonstrated that certain sociopsychological characteristics reported to be attributes of male officers are not possessed by female police officers. His study was conducted almost 20 years ago and was limited in scope by the small number of females and the types of duties available for women to perform. The intervening years have witnessed a significant increase in the number of female police officers and the range of their duties; a potentially larger, more representative sample is now available for testing.

\section{PROBLEM STATEMENT}

The problem this study addressed was the lack of valid knowledge about work-related characteristics of female police officers, particularly those characteristics that might be related to the emerging proactive nature of policing under the new paradigm.

In an attempt to validate some of the initial findings produced by the Perlstein (1971) examination of female police, the scope of this study was limited to four characteristics: anomia, authoritarianism, job satisfaction and morale, and reason for choosing law enforcement as a police profession.

This study tested essentially the same major hypotheses as the Perlstein (1971) study. The degree of anomia, authoritarianism, job satisfaction and morale, and the 
reason for choosing law enforcement as a profession are not related to certain demographic characteristics of female police officers.

Data were gathered from a non-random sample of female police officers using a questionnaire that was basically the same as the one used in the Perlstein (1971) study.

\section{THEORETICAL FRAMEWORK}

Because the nature of this study was mostly exploratory, it was not conducted within the framework of a specific theory. However, the study was based on the following basic assumptions:

1. Sociodemographic characteristics of respondents were a source for evaluating beliefs.

2. A person's attitude is determined by collective beliefs concerning a specific object or event. Attitude may generally be measured by assessing beliefs. Police officers are believed to hold several distinct beliefs toward police service and the constituents they serve. Background characteristics establish their attitudinal patterns.

3. Female police officers working in police departments share the same characteristics as their counterparts attending professional conferences.

4. The fact that a female police officer's spouse is also employed in the criminal justice system will not affect responses to survey questions.

Definitions of the important terms used in the study are:

1. Anomia: Social malintegration; associated with rejective orientation toward out-groups in general and minority groups in particular, i.e., excessively suspicious of all persons with whom police officers interact, either personally or professionally. 
2. Authoritarianism: Unquestioning obedience to authority, as opposed to individual freedom of judgment and action, i.e., the sublimation of individual discretion in favor of narrowly defined departmental rules.

3. Job satisfaction: The difference between what an individual expects of a particular facet of work and what he or she experiences, i.e., how well agency mission and goals meet police officers' personal needs in relation to their work.

4. Morale: A mental condition with respect to enthusiasm and willingness to endure hardship within a group, in relation to a group or within oneself, i.e., police officers' agreement with, and willingness to adopt departmental mission and goals as their own.

5. Female police officer: A female assigned to perform the same duties as male police officers, i.e., routine patrol, undercover narcotics, or homicide detective duties.

6. Nontraditional occupation: Professions in which females are less than $\mathbf{3 0}$ percent of the work force, i.e., women currently constitute 8.3 percent of the police officer population.

7. Sworn status: Legal authority to affect an arrest, i.e., normally referred to as commissioned, which empowers an individual to make arrest decisions based upon discretionary authority to interpret the law.

8. Line duties: Generally associated with those duties in which direct contact with complainants, victims, and offenders is the rule, i.e., performing patrol duties.

9. Women of color: Non-white women, i.e., Black, Asian, Native American, and Hispanic. 


\section{CHAPTER II}

\section{SELECTED REVIEW OF THE LITERATURE}

\section{PERFORMANCE STANDARDS}

The problems faced by women who aspire to become police officers appear to be based upon perceptions and biases. The empirical evidence, however, seems to dispute the proposition that gender is a significant factor in predicting performance abilities and competency standards. There are research findings which support the proposition that female police officers meet or exceed the competency standards, as demonstrated by male officers (Balkin, 1988). At the same time the literature indicates that male police officers and supervisors continue to question female officer competence (Milton, Abramowitz, Crites, Gates, Mintz, and Sandler, 1974; Sherman, 1975; Charles, 1982; Kennedy, 1983; Inwald and Shusman, 1984; Greenan, 1987; Weisheit, 1987; Balkin, 1988).

Over at icast the past two decades, female police officers have strived for acceptance by their male coworkers, police administrators, and the communities they serve. The dilemma they face was described by Kanter's (1977a) observation that women do not have to work hard to have their presence known, but must work very hard to have their achievements noticed. She posited that female gender reduces the room for error, which is otherwise afforded to male colleagues. Male success tends to be attributed to skill, but female success is considered to be luck (Deaux and Enswiller, 1974; Bowersox, 1981; Romero and Garza, 1986). 
Astrand (1956) reported that employment of females in traditional male occupations is confounded by tradition and prejudice. The problem is more psychological and social rather than physical. Indeed, the International Association of Chiefs of Police, in 1971, reported that police fatalities and injuries are related more to training and the ability to think clearly than to physical strength (Sherman, 1973).

A common misunderstanding is that police officer duties are mostly associated with physically violent circumstances. On the contrary, there is a significant amount of data which support the fact that 80 to 90 percent of police work involves noncriminal and service functions, most of which do not require a significant amount of physical activity (Bell, 1982b). Sherman (1973) reported:

The almost universal notion is that police work is mainly a matter of crunched bones, blackened eyes, and bullet wounds, and that a police officer's life is a never-ending series of death-defying confrontations with ferocious goons, desperate fugitives, and thrill-seeking psychopaths. Like so many heroic images of our past, this one will not stand up to examination (p. 390).

Balkin (1988) reported the results of a study by the Philadelphia Police Department which concluded that women should not be assigned to patrol duties. Over a two year period, the performance of 100 male and 100 female officers was monitored and evaluated in an effort to establish a response to a discrimination suit filed against the department. The study found that "women do not project the impact of strength and power to the same degree as male officers" (Balkin, 1988, p. 32). It also found that males rated higher on building searches, and that "women were as diligent as men in making arrests, with no difference in the number of arrests, and rated the women better at handling clients with gun, family disturbances, and car stops" (Balkin, 1988, p. 32). The 
ruling federal judge accepted the findings of the report, but not the conclusions. The judge's action compelled the Philadelphia Police Department to stop discriminating against female police officers. This study is an example of institutional discrimination against females being police officers. Even though the evidence was clear that women were rated well, the police department was unwilling to accept them as equals to their male counterparts.

Charles (1981) offered that there were no reports in the literature which question female police officers' performance because they lacked sufficient strength or aggression. Lehtinen (1976) suggests that only one percent of police work is too physically demanding for women--as well as for men. Through a careful examination of the literature, it seems rather clear that the perception of police physical performance criteria cannot withstand critical challenge when used to evaluate the work of female police officers.

\section{LEGAL PRECEDENTS}

The legal authority to even compete for police officer jobs has taken many years to be established. Title VII of the Civil Rights Act of 1964 was intended to remove discriminatory employment practices which were based upon race, religion, national origin,

color, and sex (Bayley and Garofalo, 1989; Steel and Lovrich, 1987). The original legislative proposal did not include sex. It was added to the Act by a white-supremist legislator in hopes that inclusion would cause the bill to be defeated. However, through the efforts of Representative Martha Griffith, Democrat from Michigan, the Act was passed with the word sex included (Bergmann, 1986). However, there were legal and practical limitations to its total implementation (e.g., the act only placed employment 
restrictions in the private sector). However, between 1964 and 1972 the force of the Civil Rights Act was expanded through Executive Orders 11246 and 11375, which prohibited discrimination by federal contractors, subcontractors, and federal agencies; and 11478, which prohibited discrimination in federal government employment (Charles, 1982; Bayley and Garofalo, 1989).

In 1972, Congress amended the Civil Rights Act of 1964 to include the provisions of the supplementing Executive Orders. It was not until then that women were supported by the authority of law in their quest to enter the police profession as full and equal members.

Regardless of the law, the single most important hurdle facing female applicants is the pre-employment testing process, almost all of which is based on male standards. The employment process and standards have been impacted by court decisions, which were necessary for enforcement of the provisions of the Civil Rights Act.

For example, in Griggs vs. Duke Power Company (1971), the court struck down entry level and promotion educational requirements unless they were proven to be directly related to job performance. Historically, female police applicants were required to possess higher educational achievements and a background which included formal training and experience in social work, as well as a pleasant personality (Bell, 1982b). These educational requirements were significantly higher than high school diploma or GED equivalent needed by males.

In Albermarle Paper Company vs. Moody (1971), the court expanded the Griggs decision. The court required that whatever means were used in a selection process must 
be job related and prove to be the least discriminatory (Gaines, Costello, and Crabtree, 1990; Bergmann, 1986).

The Griggs and Albermarle decisions developed the theories of adverse impact or protected class as the keys to determining discriminatory practices. The courts have interpreted adverse impact/protected class in terms of rejection rates (the four-fifths or 80 percent rule). This meant that selection rates for minorities, including women, must not be less than 80 percent in "any one phase" of the selection process. The testing and selection process for police candidates consists of several stages: written examination, physical agility test, oral interview, background investigation, psychological test, medical examination, and in many jurisdictions a polygraph examination. The 80 percent rule has particular meaning in police applicant testing because unsatisfactory performance at any one phase can disqualify a candidate from proceeding to the next phase (Gaines et al., 1990). Evidence provided by Martin (1990) reported that 20 percent of female applicants are offered employment. Based upon the 80 percent acceptance standard, the adverse impact rule is not being met.

In Smith vs. The City of East Cleveland (1973), the court ruled that height (5'7") and weight (150 pounds) requirements were discriminatory because they eliminated 97 percent of all females. Further, after evaluating a significant amount of expert testimony, it was ruled that "larger size did not improve performance" (Armat, 1981, p. 273). Milton et al. (1974) reported the absence of empirical data which supports the assumption that height relates to strength. Further, a 5'7" requirement also excludes 45 percent of American men. In spite of the evidence concerning height requirements, four percent 
of municipal police departments maintain height $\left(5^{\prime} 4^{\prime \prime}\right)$ and weight (135 pounds) requirements (Martin, 1990).

The law requires police agencies develop selection standards that are nondiscriminatory in response to the adverse impact rule. As a result, women have been more successful in entering the profession as patrol officers, increasing from zero in 1967 to 8.3 percent in 1989 (U.S. Department of Justice, 1990). With that substantial increase, however, women appear to be confronted with new challenges. Lehtinen (1976) described the current dilemma facing women in police: "They are fighting injustice within the police department more than on the streets" (Balkin, 1988, p. 33). This fact was clearly made by Martin (1990) in which she reported that women only comprise 3.3 percent of all supervisory positions.

\section{PRE-EMPLOYMENT TESTING}

In spite of legislative and legal authority, women were still deterred because preemployment physical performance tests (agility) were based upon male standards. There is no precise body of knowledge which identifies the specific degree of strength or fitness needed to perform the physical tasks of policing (Charles, 1982; Sherman, 1973; Bell, 1982b). Historically, physical strength and courage were required, even though these arguments are easily refuted by empirical evidence (Lord, 1989; Bayley and Garofalo, 1989).

Women generally have a more difficult time passing the pre-employment physical agility tests because of the emphasis on upper body strength (Weisheit, 1987). Further, post-hiring training does not address maintenance or improvement of physical skills of 
either women or men. Wexler (1983) reported the minimal training that does exist is not directed toward all officers--only those who are taller (6 foot). A Los Angeles Police Department study suggested significant problems with physical agility testing. A higher percentage of women than men passed the written, psychological, and background portions of the testing process. The same percentage passed the oral and medical examinations. However, only 23.5 percent of women passed the physical agility test compared to 96.4 percent of men (Milton, et al. 1974). The physical agility test eliminates a majority of female applicants even though the evidence is suspect as to its validity. Narsh (1962) reported that the best performance indicators, which the preemployment process is supposed to evaluate, are written test scores, and that females appear to outperform males in this area.

Physiologically, women are not as strong as men. Women develop between 60 and 80 percent of the strength of men, depending on the muscle group studied (Charles, 1982). Women, however, can double their strength in 12 weeks. It cannot be successfully argued that some degree of physical strength is unnecessary in police work, the issue is how much work is really necessary.

The physical testing process includes an assessment of upper body strength. Even though the need for upper body strength in police work is currently under dispute (Weisheit, 1987; Lord, 1989; Sherman, 1973; Charles, 1982), the ability to perform pull-ups is considered to be a measure of anaerobic strength, or short-term brute force. This upper body strength is a special problem for females because their socialization process does not place emphasis on development of brute physical strength to resolve disputes. Rather, women tend to resort to a series of nonviolent and nonphysical 
techniques to resolve conflicts (Washington, 1981). Even though the evidence is in dispute as to the needed degree of physical strength, it continues to be used as a measurement of police ability. The absence of quantitative data leads to qualitative speculation by males and police administrators who stress the dangerousness of police work (Balkin, 1988).

\section{EMPLOYEE CHARACTERISTICS}

Males engaged in the law enforcement profession have been extensively studied in an attempt to determine their attitudes and behavior characteristics (Beutler, Nussbaum, and Merideth, 1988); stress (Lester, 1982); changing career orientations (Burke and Deszca, 1988); attitudes and background characteristics (Davis, 1984); authoritarianism (Stewart and Hoult, 1979; Austin, Hale, and Ramsey, 1987; Balch, 1972; Genz and Lester, 1976; Niederhoffer, 1967); predispositional model (Bennett and Greenstein, 1975); reasons for choosing law enforcement (Meagher and Yentes, 1986); leadership (Bell, 1982b); and attitudes about rotating shifts (Sherman, 1975; Lester, 1986). It should be noted that these studies were predominantly oriented to post-hiring manifestations. Pre-employment standards for police officers did not begin until females began entering the profession.

One of the first and probably the most prominent study of male police officer characteristics was conducted by Niederhoffer (1967). His research of police cynicism, anomia, authoritarianism, and job satisfaction may be one of the most often quoted sources in police literature. His 1967 study reported that male police officers were high in cynicism, authoritarianism, anomia, and dissatisfaction with their jobs. 
Perlstein (1971) expanded the body of knowledge on police officer characteristics when he reported that anomia and authoritarianism were not exhibited by the female police officers he sampled. Additionally, he reported that females were not dissatisfied with their jobs, and chose the profession for different reasons than did men. Security was determined to be the reason for choosing police work among 60 percent of males and 49 percent of females. In both instances, job security was an important factor. These results are consistent with the proposition offered by Balch (1972): "most police come from working-class homes, but share those middle-class values of getting ahead, and owning a home and a new car. These goals can be fulfilled in the police profession which offers reasonably good pay without a college education or special training" (p. 116). This is especially relevant to females, because the entry level salary is generally higher than for other positions traditionally held by women (Meagher and Yentes, 1986).

Niederhoffer's (1967) research was limited to the New York City Police Department. Perlstein's (1971) findings were based upon a more geographically diverse population. Perlstein's research is important because it was the first such effort to determine why females chose the police profession, and to study their levels of anomia, authoritarianism, and job satisfaction and morale. Perlstein surveyed 14 police agencies, which had a total female police officer population of 150,138 of which responded, for a remarkable response rate of 92 percent.

It could be suggested that the contradictions between Niederhoffer (1967) and Perlstein (1971) may have been the result of differences in study populations. If Niederhoffer established the benchmark for males, it can also be suggested that Perlstein did the same for female police officers. 
The answer to the question as to similarity of characteristics between male and female officers is incomplete. Female police officers now perform all of the line duties previously reserved for males. The increase in absolute numbers of female police officers with more on-the-job line experience offers the potential for a larger, more representative sample. Therefore, current, accurate, and relevant data are essential to either support or refute arguments concerning the present and future employment of females as police officers on a par with males.

According to Chief William H. Parker of the Los Angeles Police Department, "an attitude . . . frequently [found] among well intentioned people is that the police officer is sometimes a frustrated dictator who is attracted to the police service in order to give vent to his aggressive or neurotic feelings" (Niederhoffer, 1967, p. 103). Additionally, David Rapaport was quoted: "This adjustment as a patrolman may have been in many cases, an effort of sublimation on the choice of a mode of life where their restlessness or aggression found a socially acceptable form of expression" (Niederhoffer, 1967, p. 103).

The sum of these observations suggest that certain personality traits are drawn to the police vocation because of some inherent abnormality. Rhead, Abrams, Trosman, and Margolis (1968) observed that the personality structure of the normal police officer is considered to be pathological. Choosing the police vocation may be predetermined by certain personality traits which can be fulfilled in the police environment, commonly assumed to be conservative, authoritarian, and anomic (Talarico and Swanson, 1982). Many vocations are associated with personality stereotypes: finger-snapping advertising man; spinster school teacher; absent-minded professor; do-gooder social worker; and sensitive artist (Kennedy and Homant, 1981). Further, according to Kennedy, the role 
of police requires the execution of authority; therefore, they are deemed authoritative. The police as a social group tend to share similar attitudes about in-groups and out-groups. Presumably, their personality needs are fulfilled by their work environment. Based upon these assumptions, it could be reasonably concluded that police officers should be able to achieve a high degree of job satisfaction. However, the evidence may contradict such a conclusion.

Police officers have been described as rigid, authoritarian, conservative, and traditionalist, the which results in their inability to apply new solutions to present problems (Dalley, 1975). Previous research has also described male police officers as authoritarian, anomic, cynical, and dissatisfied with their jobs (Niederhoffer, 1967). If these propositions are universal, there should be no differences between genders. If all occupational variables are the same, except for gender, the determinants of attitudes may be based upon background characteristics.

Matarazzo, Allen, Saslow, and Weins (1964) studied 243 male fire and police applicants over a three-year period between 1959 and 1962 . Their findings revealed that some of the personality needs of police candidates were higher than the average man in terms of "needs for achievement, exhibitionism, intraception (ability to analyze and understand feelings and behaviors of others), dominance, endurance, and heterosexuality (masculine interests)" (Matarazzo et al., 1964, p. 128). Additionally, Matarazzo et al. (1964) reported that police candidates scored lower than the average man in terms of "autonomy (need to work independently), succorance (need for encouragement, kindness, and help from others), nurturance (need to forgive, sympathize with, or to help friends and strangers who are sick or in trouble), and aggression (need to criticize others, to tell 
them off, or get revenge)" (p. 128). According to Matarazzo et al., none of these characteristics were pathological. On the contrary, they reported that young male police officers were predisposed to occupations that involve helping people. Matarazzo et al. reported Kole's comparison of police candidates with University of Oregon Medical School graduates for the years 1961 and 1962. Based upon the comparison data obtained from these self-reporting studies, it was determined that police candidates reflect personality adjustments that are more normal than medical school graduates. The Matarazzo et al. data were reanalyzed in order to ascertain adjectival characteristics and were determined to be: "(a) action is preferred to contemplation; (b) manner and style of behavior are masculine; (c) natural and free from pretense; (d) range of interests are narrow; (e) behaviors are socially appropriate; and (f) gets along well in the world as it is" (Hogan, 1971, p. 680). In contrast with this profile, females tend to be more assertive and nonconforming, and to have higher energy levels than males. They are also less likely to identify with traditional sex roles than males (Carpenter, 1987).

The findings of Matarazzo et al, (1964) are limited by the persons studied as well as the geographical milieu they represent. Niederhoffer (1967) and Perlstein (1971) studied the specific manifestations of certain personality traits. One was authoritarianism which, according to Niederhoffer, is a trait of male police officers, but was not found among the women studied by Perlstein.

Authoritarianism as a major personality theory was refined in studies of antisemitism (Adorno, Frenkel-Brunswik, Levinson, and Sanford, 1950). According to Adorno et al., persons who exhibit prejudicial attitudes are characterized by anti-democratic beliefs. Those persons manifest attitudes which are uncritical, subservient 
and tend to glorify persons who represent authority. Further, they have a propensity to favor punishing those who disagree with them, in the name of an authority figure.

Authoritarian attitudes exhibited by police officers consume an extensive amount of the scholarly literature (Plant, 1960; Smith, Locke, and Fenster, 1970; McDill, 1961; Bennett and Greenstein, 1975; Culbertson, 1975; Genz and Lester, 1976; Coleman, 1982; Waddington, 1982). The frequent association of authoritarianism with police officers suggests that this particular personality trait is an attribute shared by all police officers, despite the ironic fact that it is not conducive to the tasks of modern policing (Goldstein, 1990).

Niederhoffer (1967) and Perlstein (1971) measured authoritarianism using the Adorno et al. (1950) (F or Fascism) scale. Rokeach (1956) suggests that the F scale, as a measurement of authoritarianism, is limited because it is tied too closely with ethnic intolerance. It has been observed that there are persons high or low in prejudice who exhibit varying degrees of authoritarianism. The Adorno (F) scale neglects left authoritarianism. In order to overcome this limitation the Dogmatism (D) scale was developed as a measurement of general authoritarianism, not limited by left, right, center, political, or religious manifestations. Dogmatism is defined as:

(a) a relatively closed cognitive organization of beliefs and disbeliefs about reality, (b) organized around a central set of beliefs about absolute authority which, in turn, (c) provide a framework for patterns of intolerance and qualified tolerance toward others (Rokeach, 1956, p. 2).

Authoritarianism is a psychological phenomenon and is not limited to police professionals. Balch (1972) reported that authoritarianism, as a personality syndrome, is widespread throughout society; the real question is not "why are policemen 
authoritarian [but] why are policemen singled out for special attention" (p. 117). Due to the nature of police work, whether or not police officers are authoritarian may be related to their degree of anomia and job satisfaction.

As previously reported, Matarazzo et al. (1964) found that candidates he studied scored below average on authoritarianism as measured by their scores on the MMPI. Saxe and Reiser (1976) reported that, based upon MMPI profiles, police appear to be psychologically healthy, but there is a great degree of variance within the normal range. The issue appears to be related to the clinicians ability to classify candidates as suitable or unsuitable (Hargrave, 1985). Shoenfield, Kobos, and Phinney (1980) reported that clinician decisions were no better than chance. Johnson (1983) suggests caution against unquestioning reliance on the MMPI because the literature is mixed as to its efficacy.

The question as to whether or not authoritarianism is a good or bad trait, and inherent with police officers, remains open to interpretation. The attendant question as to the existence of authoritarian traits among police officers is testable and warrants inclusion in the present study. Niederhoffer (1967) reported that the nature of police work transforms police officers, even though they were not predisposed to that trait, into being authoritarian. The conclusions reached by Perlstein (1971) based upon gender directly contradict those of Niederhoffer. This contradiction gives rise to a discussion of the predisposition versus socio-culture paradigm, which offers two different mechanisms whereby personality traits are developed.

Bennett and Greenstein (1975) reported a partial explanation of the paradigm. Their study compared value attitudes possessed by police officers, police science majors, and non-police science majors. If the police officers and police science majors exhibited 
like values and were different from non-police science majors, the predispositional model may be partially explained. However, they reported no statistical relationship between the tested values of police officers and police science majors. At the same time, the police science and non-police science majors demonstrated similar values. These data are consistent with the proposition that police officer attitudes are the result of a socio-culturation process (Niederhoffer, 1967). It should be noted that there was no gender differentiation in the Bennett and Greenstein (1975) study.

Smith et al. $(1967,1968,1970)$ conducted thīce separate studies in an attempt to determine the authoritarianism levels among police officers, police officers in college, police science majors, and non-police science majors. They found no evidence that there was an inordinate amount of authoritarianism among police officers, although authoritarianism levels were significantly different between college and non-college police officers, the latter being higher.

According to Matarazzo et al. (1964) the police officer candidates he studied possessed characteristics which were representative of the working class. $\mathrm{He}$ characterized them as:

Typical of the enlisted men one often encounters in the military services: blustery, sociable, exhibitionistic, active, manipulating others to gain their own ends, opportunistic, unable to delay gratification, impulsive, and showing some tendencies toward over indulgence in sex and drinking ... fitting the lower socioeconomic group's stereotype of the "man's man" (p. 131).

Meier and Bell (1959) reported that the working class is higher in anomia. But Niederhoffer (1967) concluded that the male police officers he studied scored low on the Srole Anomia Scale. Niederhoffer's proposition was based upon the premise that those 
entering police work were expected to score low because they were achieving success, by virtue of becoming police officers. Eric Fromm said that "among personalities basically fitted for a democratic society, escape reactions from socially generated aloneness and helplessness (individual anomia) may issue either in authoritarianism or compulsive conformity" (Srole, 1956, p. 716). This suggests that police officers, while not exhibiting anomia, may manifest authoritarianism and conventionalism instead of anomia.

The greatest threats to individual police officers, in terms of anomia, are the duties they perform and the organizational structure in which they must function. McDill (1961) described anomia as a perception the individual possesses concerning being controlled by external forces. Of special note are college graduates or women who appear to be at the greatest risk of becoming anomic because of frustration and the routine nature of police work (McDill, 1961).

The police organization, based upon the paramilitary model, is considered to be an external control, and discourages upward communication. Women and the college educated become alienated by their inability to communicate their personal attitudes and reactions to the functional aspects of the organization. These intraorganizational relationships create stresses on occupational aspirations of educated female police officers (Rhodes, 1964).

Perlstein's (1971) research assumption that the type of work females perform will be directly related to their degree of anomia was not supported by his results. He suggested that women assigned to duties like vice would exhibit a higher degree of anomia because they are exposed to the negative aspects of human society. In the case 
of males, Niederhoffer (1967) found significant correlation between type of job and anomia.

According to Perlstein (1971), background characteristics of female police officers should be related to their degree of anomia. His proposition is supported in part by Rhodes (1964) who reported that education, socioeconomic status, and urban residence are related to anomia. However, Perlstein's findings did not support such a generalization.

Matarazzo et al. (1964) reported that the candidates they studied reflected a need for challenging work. The nature of police work supports the psychological characteristics of need exhibited by his study. Their findings are consistent with those determined by Morse (1953) in which she offered that jobs which are more varied, and require more skill and decision-making are most satisfying. According to the Morse (1953) criteria, police duties by their very nature are widely varied and require decision-making, which suggests a high degree of job satisfaction is achievable.

Morse (1953) reported that recent hires and younger employees are more satisfied and enthusiastic. Their attitudes are based on several factors, most of which are outside the organization (friends, relatives, and community prestige). However, as their time on the job increases, they begin to realize limited advancement opportunities. That, in addition to the type of work environment and the work itself, causes dissatisfaction and a loss of enthusiasm.

There appears to be a direct relationship between aspiration (need), education, and job satisfaction. The higher the education level, the higher the level of aspiration--if the aspirations are met, the result is job satisfaction (Morse, 1953). Consequently, if the 
environment does not provide adequate need fulfillment, those with the strongest desires will be least satisfied. Workers who are brighter require more intellectually challenging tasks. If the nature of their work does not create an intellectual challenge, they tend to be low on satisfaction and quit for higher positions (Super, 1957).

Bernberg (1954) reported that the relationship between age and job satisfaction/morale is cyclical. As age increases so does morale, regardless of length of service.

The literature on authoritarianism, anomia, and job satisfaction reflects that all are testable phenomena. Authoritarian behavior attributed to police officers has been extensively researched and tested on males but not females. Anomia and job satisfaction, on the other hand, have not had equal interest, with either gender. 


\section{CHAPTER III}

\section{RESEARCH DESIGN}

\section{GENERAL DESCRIPTION}

Data were collected from a non-random sample of female police officers using a structured questionnaire which contained several validated instruments to assess job satisfaction and morale, anomia, and authoritarianism. Hypotheses were tested using Chi-Square and product-moment correlation coefficients; demographic characteristics were analyzed with multi-variable statistical techniques.

\section{DATA SOURCES}

This study is nonprobability by design. A purposive-available population method of data collection were employed. This method was selected because of general lack of an accessible frame (police officers). Study of police officers requires the researcher be granted permission by the employing agency. Officers' names are a matter of public record; however, addresses and telephone numbers are generally not available for public access. Therefore, research is limited to those officers who agree to complete survey instruments distributed by police agencies.

The study population included female police officers in those cities listed in Table

I. The table reports the questionnaire response rates and percentages of total respondents from each city. The chiefs of police for each city were requested to allow 
their female police officers to participate in this study. A copy of the questionnaire (Appendix A) was provided with the letter of request. The cities studied are the same as those surveyed in the 1971 Perlstein study, except for Atlanta, Georgia; Honolulu, Hawaii; Montgomery, Alabama; Oakland, California; Seattle, Washington; and St Louis, Missouri; which declined to participate. Upon notification that the agency would participate, an appropriate number of surveys were mailed to the police department for dissemination, completion, and return to the university in postage paid envelopes.

TABLE I

RESEARCH POPULATION BY NUMBER AND PERCENT

\begin{tabular}{||l|c|c|c|c||}
\hline City & $\begin{array}{c}\text { Total Female } \\
\text { Officers }\end{array}$ & $\begin{array}{c}\text { Total Number } \\
\text { of Responses }\end{array}$ & $\begin{array}{c}\text { Total } \\
\text { Response Rate }\end{array}$ & $\begin{array}{c}\text { Percent of } \\
\text { Sample }\end{array}$ \\
\hline \hline Baltimore & 303 & 115 & 37.9 & 14.7 \\
\hline Cincinnati & 80 & 27 & 33.7 & 3.4 \\
\hline Fort Worth & 120 & 73 & 60.8 & 9.3 \\
\hline Kansas City & 135 & 75 & 55.5 & 9.6 \\
\hline Miami & 127 & 35 & 27.5 & 4.5 \\
\hline Minneapolis & 79 & 44 & 55.6 & 5.6 \\
\hline New Orleans & 135 & 28 & 20.7 & 3.6 \\
\hline Philadelphia & 965 & 216 & 22.3 & 27.5 \\
\hline IAWP & 414 & 170 & 41.3 & 21.8 \\
\hline TOTAL & 2,358 & 784 & 33.2 & 100.0 \\
\hline
\end{tabular}

In addition to the mail questionnaires from the selected police departments, attendees at the 1990 annual seminar of the International Association of Women Police (IAWP) in Minneapolis, Minnesota, were surveyed through an on-site dissemination and collection of questionnaires. The selection of this group was based on convenience and 
availability of 'swom female police officers--the targeted population. It was assumed that both groups of sworn female police officers shared enough common characteristics to merge them into one study population.

The total population of this study was 2,358 female police officers; 784 returned questionnaires for an overall return rate of 33.2 percent.

\section{QUESTIONNAIRES}

\section{Description}

The questionnaire was divided into four sections:

Section 1 was designed to capture some basic socio-demographic data of each respondent and certain beliefs they hold regarding police work. The information provided was used in connection with analysis of their degree of anomia, job satisfaction and morale, authoritarianism, and why they chose law enforcement as a profession. The form was altered for those respondents at the IAWP seminar to include the state in which they were employed.

It was suggested to the author that including the occupation of the respondent's mother may affect the socioeconomic status scoring of the family, especially if it was higher than respondent's father. Inclusion of this information may be relevant to the analyses proposed in this study. Whether or not their spouse is employed in the criminal justice system may also be relevant: if a spouse is employed in the criminal justice system it may present a potential bias affecting their responses.

Section 2 was a 9-item Likert-type scale developed by Nancy Morse (1953) as a measure of job satisfaction and morale. Each of the items provide for five responses 
ranging from 1 (strongly negative) to 5 (strongly positive), with 3 being a mid position (undecided). McNeely (1983) reported that the Morse scale was sensitive and allowed for an assessment of intrinsic job satisfaction.

Section 3 was a 5-item Likert-type scale developed by Leo Srole (1956) as a measure of anomia. Srole developed the scale in connection with his studies of authoritarianism as a concept of social integration. Each of the scale items range from 1 (strongly disagree) to 5 (strongly agree), with 3 as a mid position (undecided). Rhodes (1964) employed the scale in his research into the relationships between anomia, aspiration, and status. Neither Srole or Rhodes reported on the validity of the scale. However, the use of the scale is so extensive that it has been designated by the American Institute for Scientific Information as a "classic citation" (Babbie, 1989, p. 117).

Section 4 was a 10-item Likert-type scale developed by Rokeach (1956). The Dogmatism (D) scale is designed to measure a manifestation of authoritarian attitudes which are politically and religiously neutral. The primary thrust of the dogmatism scale relates to ethnocentrism. Each of the scale items range from 1 (strongly disagree) to 7 (strongly agree), with 4 as a mid position (undecided). Rokeach reported the reliability coefficients of the D scale range between .70 and .91 . Teasley and Wright (1973) reported test-retest reliability coefficients between .68 and .93 . See Appendix A for complete questionnaire.

\section{Administration}

The participating police departments provided the author with their number of sworn female police officers, at which time the appropriate number of surveys were mailed to each department. In some instances the departments attached a cover letter 
to the questionnaires reaffirming that participation was authorized by the chief and that to do so was completely voluntary. Attached to each questionnaire was a postage-paid envelope addressed to Portland State University. This portion of the data collection was completely by mail survey.

The International Association of Women Police, on the other hand, was accomplished by on-site dissemination and collection. The coordinators of the seminar provided the author with the number of attendees. Complete sets of the questionnaires were mailed to the conference coordinating committee. The committee placed one in each attendee's conference packet, which were then issued to each attendee at time of registration. The author attended the seminar and provided a collection container which was monitored throughout the duration of the conference. At the beginning session, each day of the seminar, attendees were encouraged to participate in the survey and deposit completed questionnaires in the collection container.

\section{DATA ANALYSIS}

Analysis of the data will vary with class of measurement, nominal or interval/ratio. Analysis techniques were selected based upon class of measurement employed, and are presented in subsequent sections along with appropriate hypotheses.

\section{Unit of Analysis}

The unit of analysis in this study was the female police officer. The author acknowledges that operationally defining the characteristics associated with this study, as well as any attempts to use similar data, does present certain problems because of 
imperfections, errors, and fallibilities of the measuring instruments. Ash (1954) suggested the following sources of error with survey instruments:

1. They tend to reduce and divide what is more or less a total view to a series of discrete, equally weighted items.

2. They pose questions possibly related to attitudes in a language that is not necessarily the language of the respondent.

3. They probably ask some questions that are irrelevant, and omit others that may be highly relevant.

4. Among relevant items, the measure provides no difference in weight as between those that are salient and those that are minor (p. 340)

\section{Variables}

Reasons for choosing the law enforcement profession. Previous studies have identified the reasons as: security (pay and promotions), excitement (varied and out-of-doors work), and helping (want to help people) (Niederhoffer, 1967; Bayley and Mendelsohn, 1968; Perlstein, 1971; Balch, 1972; Burk and Deszca, 1988; Slater and Reiser, 1988). In the present study, another reason--career goal--was identified and included in the analysis. This category, had not been previously addressed in the literature.

Job satisfaction and morale. The question is whether or not female police officers are satisfied with working in a non-traditional occupation. In the classic sense, job satisfaction is thought of as the difference between what one expects in their work and what they actually experience (Summers, 1988).

Anomia. This variable is designed to measure degrees of alienation, anxiety, and feelings of powerlessness. Srole (1956) described this state of mind as "social malintegration, associated with a rejective orientation toward out-groups in general and 
toward minority groups in particular" (p. 712). It has been suggested that becoming anomic is associated with police officers because of the negative attitudes they develop about citizen-clients in the normal course of their duties (Niederhoffer, 1967; Bayley and Mendelsohn, 1968; Perlstein, 1971; McNeely, 1983; Terry, 1989).

Authoritarianism. Stewart and Hoult (1979) describe an authoritarian as, "One who is rigidly ethnocentric, anti-democratic, compulsively conventional, punitive and condescending toward those regarded as inferior, and submissive to authority" (p. 274). The police operate in a quasi-militaristic structure, with little use for democratic decisionmaking or informed dissent, which is believed to produce individuals with rigid concepts of order-authoritarian (Reming, 1988; Bell, 1982a).

Background characteristics. Age, religion, race, education level, socioeconomic status, marital status, college major, tenure, and rank were the variables associated with reason for choosing law enforcement as a profession, job satisfaction and morale, authoritarianism and anomia. These variables are the same employed by Perlstein, except for tenure, college major, and rank, and are used in the present study. One variable, whether or not they reside in the city where they are employed, was not addressed in this study. It became clear to the researcher that in most instances residency was required, which eliminates that issue of choice. Summary tables of variable responses are in Appendix B and Appendix C.

\section{Socioeconomic Status}

This variable posed some problems because it is actually a measurement of occupation prestige. According to Duncan, Hatt, and North (1961), index scores are predicted prestige scores which are regressed on levels of income and education. The 
Sociocconomic Index (SEI) developed by Duncan et al. (1961) was updated by Stevens and Cho (1985) based upon 1980 census data. The occupations of each parent were coded according to the Stevens and Cho scale. The highest of the two occupational scores for both parents were used to determine the family background socioeconomic status. Categories of deceased, retired, homemaker, none, and unable to classify were developed which are not included in this analysis (see Appendix D). Respondents indicated a nonoccupation status in place of occupation. The efficacy of the SEI continues to be debated by scholars (Hodge, 1981; Rossi, Wright, and Anderson, 1983; Coxon, Davies, and Jones, 1986), all of whom appear to agree with the accuracy of the measurements. There seems to be debate, however, as to what is being measured.

\section{HYPOTHESIS TESTING}

The primary hypothesis of this study was: The degree of job satisfaction and morale, authoritarianism, anomia, and reasons for choosing law enforcement as a profession are not related to the background characteristics of female police officers. This hypothesis was tested by dividing it into a set of secondary hypotheses which are presented below with their individual propositional statements and dependent/independent variables.

\section{Proposition 1}

The female police officers' background characteristics can be expected to be related to their reason for choosing law enforcement as a profession. The variables are:

a. Dependent: Why female police officers chose law enforcement as a profession. 
b. Independent: Age, religion, race, years of education, socioeconomic status, rank, college major, and marital status.

Hypothesis 1. Female police officers' age at time of employment will not be found to be a significant variable in their choice of law enforcement as a profession (test: chi square).

Hypothesis 2. No significant relationship will be found between female police officers' religion and why they chose law enforcement as a profession (test: chi square).

Hypothesis 3. No significant relationship will be found between female police officers' race and why they chose law enforcement as a profession (test: chi square).

Hypothesis 4. No significant relationship will be found between female police officers' years of education and why they chose law enforcement as a profession (test: chi square).

Hypothesis 5 . No significant relationship will be found between female police officers' socioeconomic status background and why they chose law enforcement as a profession (test: chi square).

Hypothesis 6. No significant relationship will be found between female police officers' marital status at the time of employment and why they chose law enforcement as a profession (test: chi square).

Hypothesis 7. No significant relationship will be found between female police officers' rank and their reasons for choosing law enforcement as a profession (test: chi square). 
Hypothesis 8. No significant relationship will be found between female police officers' college major and their reason for choosing law enforcement as a profession (test: chi square).

\section{Proposition 2}

It is expected that the background characteristics of female police officers will be related to their scores on the Job Satisfaction and Morale Index. The variables are:

a. Dependent: Job satisfaction and morale.

b. Independent: Age, religion, race, years of education, socioeconomic status, rank, tenure, college major, marital status, and type of work they perform in the police department.

Hypothesis 9 . No significant relationship will be found between the female police officers' age and their Job Satisfaction and Morale Index scores (test: product-moment correlation coefficient).

Hypothesis 10. No significant relationship will be found between female police officers' religion and their scores on the Job Satisfaction and Morale Index (test: chi square).

Hypothesis 11. No significant relationship will be found between female police officers' race and their Job Satisfaction and Morale Index scores (test: chi square).

Hypothesis 12. No significant relationship will be found between female police officers' years of education and their scores on the Job Satisfaction and Morale Index (test: chi square). 
Hypothesis 13. No significant relationship will be found between female police officers socioeconomic status background and their scores on the Job Satisfaction and Morale Index (test: product-moment correlation coefficient).

Hypothesis 14. No significant relationship will be found between female police officers' tenure and their Job Satisfaction and Morale Index scores (test: product-moment correlation coefficient).

Hypothesis 15. No significant relationship will be found between female police officers' marital status and their Job Satisfaction and Morale Index scores (test: chi square).

Hypothesis 16. No significant relationship will be found between type of work female police officers perform and their Job Satisfaction and Morale Index scores (test: chi square).

Hypothesis 17. No significant relationship will be found between female police officers' college major and their Job Satisfaction and Morale Index scores (test: chi square).

Hypothesis 18. No significant relationship will be found between female police officers' rank and their Job Satisfaction and Morale Index scores (test: chi square).

\section{Proposition 3}

The female police officers' background characteristics can be expected to be related to their degree of anomia. The variables are:

a. Dependent: Degree of anomia. 
b. Independent: Age, religion, race, years of education, socioeconomic status, marital status, tenure, college major, rank, and type of work they perform in the police department.

Hypothesis 19. No significant relationship will be found between female police officers' age and their degree of anomia (test: product-moment correlation coefficient).

Hypothesis 20. No significant relationship will be found between female police officers' religion and their degree of anomia (test: chi square).

Hypothesis 21. No significant relationship will be found between female police officers' race and their degree of anomia (test: chi square).

Hypothesis 22. No significant relationship will be found between female police officers' years of education and their degree of anomia (test: chi square).

Hypothesis 23. No significant relationship will be found between female police officers' socioeconomic status background and their degree of anomia (test: product-moment correlation coefficien`).

Hypothesis 24. No significant relationship will be found between female police officers' tenure and their degree of anomia (test: product-moment correlation coefficient).

Hypothesis 25. No significant relationship will be found between female police officers' marital status and their degree of anomia (test: chi square).

Hypothesis 26. No significant relationship will be found between the type of work female police officers perform and their degree of anomia (test: chi square).

Hypothesis 27. No significant relationship will be found between female police officers' rank and their degree of anomia (test: chi square). 
Hypothesis 28. No significant relationship will be found between female police officers' college major and their degree of anomia (test: chi square).

\section{Proposition 4}

The female police officers' background characteristics can be expected to be related to their degree of authoritarianism. The variables are:

a. Dependent: Degree of authoritarianism.

b. Independent: Age, religion, race, years of education, socioeconomic status, marital status, rank, college major, tenure, and type of work they perform in the police department.

Hypothesis 29. No significant relationship will be found between female police officers' age and their degree of authoritarianism (test: product-moment correlation coefficient).

Hypothesis 30. No significant relationship will be found between female police officers' religion and their degree of authoritarianism (test: chi square).

Hypothesis 31. No significant relationship will be found between female police officers' race and their degree of authoritarianism (test: chi square).

Hypothesis 32. No significant relationship will be found between female police officers' years of education and their degree of authoritarianism (test: chi square).

Hypothesis 33. No significant relationship will be found between female police officers' socioeconomic status background and their degree of authoritarianism (test: product-moment correlation coefficient). 
Hypothesis 34. No significant relationship will be found between female police officers' tenure and their degree of authoritarianism (test: Product-moment correlation coefficient).

Hypothesis 35 . No significant relationship will be found between female police officers' marital status and their degree of authoritarianism (test: chi square).

Hypothesis 36. No significant relationship will be found between the type of work female police officers perform and their degree of authoritarianism (test: chi square).

Hypothesis 37. No significant relationship will be found between female police officers' rank and their degree of authoritarianism (test: chi square).

Hypothesis 38 . No significant relationship will be found between female police officers' college major and their degree of authoritarianism (test: chi square).

\section{Proposition 5}

The female police officers' degree of authoritarianism can be expected to be related to their degrees of anomia, job satisfaction and morale, and reason for choosing law enforcement as a profession. The variables are:

a. Dependent: Degree of authoritarianism.

b. Independent: Degree of anomia, job satisfaction and morale, and reason for choosing law enforcement as a profession.

Hypothesis 39. No significant relationship will be found between female police officers' degree of anomia and authoritarianism (test: chi square).

Hypothesis 40 . No significant relationship will be found between female police officers' degree of job satisfaction and morale, and authoritarianism (test: chi square). 
Hypothesis 41 . No significant relationship will be found between female police officers' reason for choosing law enforcement as a profession and their degree of authoritarianism (test: chi square).

\section{Proposition 6}

The female police officers' degree of anomia can be expected to be related to their degree of job satisfaction and morale, and reason for choosing law enforcement as a profession. The variables are:

a. Dependent: Degree of anomia.

b. Independent: Job satisfaction and morale scores, and reason for choosing law enforcement as a profession.

Hypothesis 42. No significant relationship will be found between female police officers' degree of anomia, and job satisfaction and morale (test: chi square).

Hypothesis 43. No significant relationship will be found between female police officers' degree of anomia and reason for choosing law enforcement as a profession (test: chi square).

\section{Proposition 7}

The female police officers' degree of job satisfaction and morale can be expected to be related to their reason for choosing law enforcement as a profession. The variables are:

a. Dependent: Degree of job satisfaction and morale.

b. Independent: Reason for choosing law enforcement as a profession. 
Hypothesis 44 . No significant relationship will be found between female police officers' degree of job satisfaction and morale, and their reason for choosing law enforcement as a profession (test: chi square). 


\section{CHAPTER IV}

\section{FINDINGS}

\section{DESCRIPTION OF THE POPULATION}

\section{Education}

The Task Force Report on Police recommended that by the year 1982 all police officers have an undergraduate college degree (Peterson, 1973). Carter, Sapp, and Stephens (1989) reported that the 1978 study by The National Institute of Law Enforcement and Criminal Justice projected that police officers with more than one year of college would increase from 46 percent in 1974 to 75 percent by 1985 . In 1989, they found that 65 percent of all police officers had one or more years of college and 22.6 percent had earned a baccalaureate degree. Contrastingly, 32 percent of the officers surveyed in the present study reported having a baccalaureate degree, with 7.1 percent of those having earned a graduate degree. In addition, 17.7 percent had earned an associate degree. The female police officers in the present study reported a mean education level of 14.5 years. In 1988 , male police officers were reported to have a mean education level of 13.6 years, and for female police officers, the mean education level was 14.6 years (Carter, et al., 1989). The Carter et al. (1989) finding regarding female police officers, is consistent with the present study. Slightly over 62 percent of the female police officers in this study reported their college major as social science. Of that total, Administration of Justice comprised 36.7 percent and other social sciences were 25.7 
percent. The remainder were divided between the humanities (10.9), sciences (6.8), and vocational (2.9), with 17 percent indicating no major (see Appendix C).

\section{$\underline{\text { Race }}$}

The racial composition of this study was quite different from the general population. The Statistical Abstract of the United States: 1990 reported that Blacks comprise 12.3 percent of the U.S. population (U.S. Bureau of the Census, 1990). The percentage of Black respondents in this study was 25.1 (195).

\section{$\underline{\text { Religion }}$}

According to The Statistical Abstract of the United States: 1990 (U.S. Bureau of the Census, 1990), Catholicism was reported as a religious preference by 28 percent of the general population. In the present study 41.8 percent (295) of the respondents reported being Catholic. Among the 706 who reported, their preferences were: Protestant 55.4 percent (391); Jewish 1.7 percent (12); Agnostic .3 percent (2); Jehovah Witness .3 percent (2); Adventist .3 percent (2); Pagan .1 percent (1); and Islam .1 percent (1). It should be noted that the abstract data, in terms of religion, was the result of several different surveys and it only reflects a preference as opposed to commitment or membership.

\section{Marital Status}

Fifty-five percent of the respondents reported being single at the time of their employment; 34 percent reported their current marital status as single. Of the surveyed female police officers, 24.6 percent were currently married to a person employed in the criminal justice system; only one reported that her spouse was employed in the criminal 
justice system at the time of her employment. Marital status of the respondents is shown in Table II.

TABLE II

MARITAL STATUS

\begin{tabular}{||c|c|c|c|c||}
\hline \multirow{2}{*}{ Status } & \multicolumn{2}{|c|}{ Entry } & \multicolumn{2}{c|}{ Current } \\
\cline { 2 - 5 } & Frequency & Percent & Frequency & Percent \\
\hline \hline Single & 432 & 55.1 & 270 & 34.4 \\
\hline Married & 198 & 25.3 & 322 & 41.1 \\
\hline Divorced & 126 & 16.1 & 164 & 20.9 \\
\hline Other & 28 & 3.6 & 28 & 3.6 \\
\hline TOTAL & 784 & 100.0 & 784 & 100.0 \\
\hline
\end{tabular}

Age

The female police officers in this study reported a mean age at the time of initial employment of 25.5 years and current mean age of 34 years (see Table III).

TABLE III

AGE DISTRIBUTION

\begin{tabular}{|l|c|c|c|c|}
\hline \multirow{2}{*}{ Age Group } & \multicolumn{2}{|c|}{ Entry } & \multicolumn{2}{c|}{ Current } \\
\cline { 2 - 5 } & Frequency & Percent & Frequency & Percent \\
\hline \hline $18-22$ & 227 & 29.0 & 23 & 3.0 \\
\hline $23-25$ & 222 & 28.0 & 45 & 5.8 \\
\hline $26-28$ & 147 & 19.0 & 125 & 16.0 \\
\hline $29-41$ & 187 & 24.0 & 378 & 48.5 \\
\hline $42-61$ & - & -- & 208 & 26.7 \\
\hline TOTAL & 783 & 100.0 & 779 & 100.0 \\
\hline
\end{tabular}


Tenure

The mean number of years of police employment was 8.5. The data of the 780 female police officers who responded to this section of the questionnaire reflect a tenure range from one month to 31 years.

$\underline{\text { Rank }}$

The percentage of respondents in the present study who had achieved supervisory rank was 20.9 , of which 5.9 percent held the rank of lieutenant or higher. Investigators and detectives constituted 11.2 percent, while the remaining 67.9 percent reported their position as police officer. In some instances the respondents referred to their rank as patrolman and policeman (see Table IV).

TABLE IV

RANK

\begin{tabular}{|l|c|c|}
\hline \hline Rank & Frequency & Percent \\
\hline \hline Officer & 522 & 67.9 \\
\hline Line Supervisors (corporal/sergeant) & 115 & 15.0 \\
\hline Staff (lieutenant and above) & 45 & 5.9 \\
\hline Investigator (detective/agent) & 86 & 11.2 \\
\hline TOTAL & 768 & 100.0 \\
\hline
\end{tabular}

\section{Work History}

Historically women entering the police profession were required to have education and experience in the helping professions (social work, nursing, and teaching). Perlstein (1971) reported that 37 percent of his population met that requirement. The present 
data indicate that 19 percent of the respondents came from such helping professions. The difference may be explained, in part, by the fact that education and training in helping professions is no longer required.

\section{$\underline{\text { Socioeconomic Status }}$}

Socioeconomic Index (SEI) scores were derived from an updated version of the Duncan SEI reported by Stevens and Cho (1985). Female police officers in this study were asked to list the occupations of both parents. The mean for fathers' occupations was 31.050 and for mothers' was 34.685 . The SEI used in this study was the Total Socioeconomic Index (TSEI) which has a mean of 34.48. Because the TSEI was used, the occupations of both parents were compared, and the highest of the two was used to determine family SEI, the result of which reflected a mean of 39.547 . The mean TSEI of respondents prior to entering the police profession was 30.430 .

\section{REASON FOR CHOOSING LAW ENFORCEMENT AS A PROFESSION}

Previous research reported reasons for choosing law enforcement as a profession such as security, helping, and excitement (Niederhoffer, 1967; Perlstein, 1971). In the present study, respondents identified the following reasons: security, 27 percent (206); helping 25.1 percent (192); excitement 24.3 percent (186); other 13.1 percent (100); and career goal 10.5 percent $(80)$. These findings were consistent with previous research in terms of their rank ordering, although the percentages are lower than those determined by Perlstein: security 38.3 percent; helping 32.3 percent; and excitement 32.6 percent. 
The lower percentages may by due to the addition of other categories. Slightly over 10 percent of the respondents reported they chose law enforcement as a profession because it was their career goal, (e.g., "always wanted to be a cop," and "a childhood dream"), and 13.1 percent were not classifiable (e.g., "no reason," "better than women's work"). These two additional categories constituted nearly one-fourth of the overall responses.

In each of the following analyses there may be differences between the total population (784) and the number of responses, because those surveys with any missing values for any variable were dropped from the calculations for that variable. The independent variables selected for this study were the same as those employed by Peristein. The chi square test of differences between variables was used to test each hypothesis.

\section{Proposition 1}

Female police officers' background characteristics can be expected to be related to their reason for choosing the law enforcement as a profession.

Hypothesis 1. Female police officers' age at time of employment will not be found to be a significant variable in their choice of law enforcement as a profession. The distribution of responses and statistical results are presented in Table V. 
TABLE V

ENTRY AGE AND REASON FOR CHOOSING LAW ENFORCEMENT BY NUMBER AND PERCENT

\begin{tabular}{|c|c|c|c|c|c|}
\hline \multirow[b]{3}{*}{ Reason } & \multicolumn{4}{|c|}{ Entry Age } & \multirow[b]{2}{*}{ Total } \\
\hline & $18-22$ & $23-25$ & $26-28$ & $29-41$ & \\
\hline & $\begin{array}{c}\text { Frequency } \\
\text { (percent) }\end{array}$ & $\begin{array}{c}\text { Frequency } \\
\text { (percent) }\end{array}$ & $\begin{array}{c}\text { Frequency } \\
\text { (percent) }\end{array}$ & $\begin{array}{c}\text { Frequency } \\
\text { (percent) }\end{array}$ & $\begin{array}{l}\text { Frequency } \\
\text { (percent) }\end{array}$ \\
\hline Security & $\begin{array}{c}42 \\
(19.00)\end{array}$ & $\begin{array}{c}55 \\
(25.23) \\
\end{array}$ & $\begin{array}{c}50 \\
(34.72) \\
\end{array}$ & $\begin{array}{c}59 \\
(32.68) \\
\end{array}$ & $\begin{array}{c}206 \\
(26.96) \\
\end{array}$ \\
\hline Helping & $\begin{array}{c}44 \\
(19.91)\end{array}$ & $\begin{array}{c}47 \\
(21.56)\end{array}$ & $\begin{array}{c}49 \\
(34.03)\end{array}$ & $\begin{array}{c}52 \\
(28.73)\end{array}$ & $\begin{array}{c}192 \\
(25.13)\end{array}$ \\
\hline Excitement & $\begin{array}{c}64 \\
(28.96)\end{array}$ & $\begin{array}{c}63 \\
(28.90)\end{array}$ & $\begin{array}{c}25 \\
(17.36)\end{array}$ & $\begin{array}{c}34 \\
(18.78)\end{array}$ & $\begin{array}{c}186 \\
(24.35) \\
\end{array}$ \\
\hline Career Goal & $\begin{array}{c}29 \\
(13.12) \\
\end{array}$ & $\begin{array}{c}22 \\
(10.09)\end{array}$ & $\begin{array}{c}7 \\
(4.86) \\
\end{array}$ & $\begin{array}{c}22 \\
(12.15) \\
\end{array}$ & $\begin{array}{c}80 \\
(10.47) \\
\end{array}$ \\
\hline Other & $\begin{array}{c}42 \\
(19.00)\end{array}$ & $\begin{array}{c}31 \\
(14.22)\end{array}$ & $\begin{array}{c}13 \\
(9.03) \\
\end{array}$ & $\begin{array}{c}14 \\
(7.73) \\
\end{array}$ & $\begin{array}{c}100 \\
(13.09)\end{array}$ \\
\hline TOTAL & $\begin{array}{c}221 \\
(100.00)\end{array}$ & $\begin{array}{c}218 \\
(100.00)\end{array}$ & $\begin{array}{c}144 \\
(100.00)\end{array}$ & $\begin{array}{c}181 \\
(100.00)\end{array}$ & $\begin{array}{c}764 \\
(100.00)\end{array}$ \\
\hline
\end{tabular}

$$
x^{2} 46.957 \quad \text { df }=12 \quad P=0.001 \quad n=764
$$

The null hypothesis is rejected. A chi-square of $<21.0$ is required to retain the null hypothesis at the .05 level of significance with 12 degrees of freedom. These data suggest a relationship between respondents' entry age and their selection of security as a reason. Female police officers who were employed after they had reached 25 years of age selected security as the main reason, with helping as second. Excitement and career goal appears to be associated with those under age 25 at time of employment as a police officer. 
Hypothesis 2. No significant relationship will be found between female police officers' religion and why they chose law enforcement as a profession. The distribution of responses and statistical results are presented in Table VI.

\section{TABLE VI}

\section{RELIGION AND REASON FOR CHOOSING LAW ENFORCEMENT BY NUMBER AND PERCENT}

\begin{tabular}{|c|c|c|c|c|}
\hline \multirow[b]{3}{*}{ Reason } & \multicolumn{3}{|c|}{ Religion } & \multirow[b]{2}{*}{ Total } \\
\hline & Protestant & Catholic & Other & \\
\hline & $\begin{array}{c}\text { Frequency } \\
\text { (percent) }\end{array}$ & $\begin{array}{l}\text { Frequency } \\
\text { (percent) }\end{array}$ & $\begin{array}{c}\text { Frequency } \\
\text { (percent) }\end{array}$ & $\begin{array}{c}\text { Frequency } \\
\text { (percent) }\end{array}$ \\
\hline Security & $\begin{array}{c}93 \\
(26.50) \\
\end{array}$ & $\begin{array}{c}80 \\
(27.97) \\
\end{array}$ & $\begin{array}{c}11 \\
(20.75) \\
\end{array}$ & $\begin{array}{c}184 \\
(26.67) \\
\end{array}$ \\
\hline Helping & $\begin{array}{c}97 \\
(27.64) \\
\end{array}$ & $\begin{array}{c}64 \\
(22.38) \\
\end{array}$ & $\begin{array}{c}8 \\
(15.09) \\
\end{array}$ & $\begin{array}{c}169 \\
(24.49) \\
\end{array}$ \\
\hline Excitement & $\begin{array}{c}76 \\
(21.65) \\
\end{array}$ & $\begin{array}{c}76 \\
(26.57)\end{array}$ & $\begin{array}{c}18 \\
(33.96)\end{array}$ & $\begin{array}{c}170 \\
(24.64)\end{array}$ \\
\hline Career Goal & $\begin{array}{c}34 \\
(9.69)\end{array}$ & $\begin{array}{c}32 \\
(11.19)\end{array}$ & $\begin{array}{c}6 \\
(11.32)\end{array}$ & $\begin{array}{c}72 \\
(10.43) \\
\end{array}$ \\
\hline Other & $\begin{array}{c}51 \\
(14.53)\end{array}$ & $\begin{array}{c}34 \\
(11.89)\end{array}$ & $\begin{array}{c}10 \\
(18.87)\end{array}$ & $\begin{array}{c}95 \\
(13.77)\end{array}$ \\
\hline TOTAL & $\begin{array}{c}351 \\
(100.00)\end{array}$ & $\begin{array}{c}286 \\
(100.00)\end{array}$ & $\begin{array}{c}53 \\
(100.00)\end{array}$ & $\begin{array}{c}690 \\
(100.00)\end{array}$ \\
\hline
\end{tabular}

$$
x^{2} 10.573 \quad \text { df }=8 \quad P=0.227 \quad n=690
$$

The null hypothesis is retained. A chi square of $>15.5$ is required to reject the null hypothesis at the .05 level of significance, with 8 degrees of freedom.

Of note is that Catholics and Protestants differed in their reasons for choosing law enforcement as a profession. Catholics' first reason was security, while Protestants ${ }^{\circ}$ first reason was helping. 
The other category was included in this analysis because some of the respondents indicated some religious affiliation (Jewish, Islam, Orthodox). Ninety-four of the respondents either did not respond or indicated none to the question.

Hypothesis 3. No significant relationship will be found between female police officers' race and why they chose law enforcement as a profession. The distribution of responses and statistical results are presented in Table VII.

TABLE VII

\section{RACE AND REASON FOR CHOOSING LAW ENFORCEMENT BY NUMBER AND PERCENT}

\begin{tabular}{|c|c|c|c|c|c|}
\hline \multirow[b]{3}{*}{ Reason } & \multicolumn{4}{|c|}{ Race } & \multirow{3}{*}{$\frac{\text { Total }}{\begin{array}{r}\text { Frequency } \\
\text { (percent) }\end{array}}$} \\
\hline & \multicolumn{2}{|c|}{ White } & \multicolumn{2}{|c|}{ Women of Color } & \\
\hline & Frequency & Percent & Frequency & Percent & \\
\hline Security & 123 & 23.21 & 82 & 36.77 & $\begin{array}{c}205 \\
(27.22)\end{array}$ \\
\hline Helping & 128 & 24.15 & 59 & 26.46 & $\begin{array}{c}187 \\
(24.44)\end{array}$ \\
\hline Excitement & 150 & 28.30 & 34 & 15.26 & $\begin{array}{c}184 \\
(24.44)\end{array}$ \\
\hline Career Goal & 57 & 10.75 & 22 & 9.87 & $\begin{array}{c}79 \\
(10.49) \\
\end{array}$ \\
\hline Other & 72 & 13.58 & 26 & 11.66 & $\begin{array}{c}98 \\
(13.01)\end{array}$ \\
\hline TOTAL & 530 & 100.00 & 223 & 100.00 & $\begin{array}{c}753 \\
(100.00)\end{array}$ \\
\hline
\end{tabular}

$$
x^{2} 22.457 \quad \text { df }=4 \quad P=0.001 \quad n=753
$$

The null hypothesis is rejected. A chi-square of $<9.49$ is required to retain the null hypothesis at the .05 level of significance with 4 degrees of freedom. The data 
suggest Women of Color chose law enforcement as a profession because of security. On the other hand, White female police officers appear to have chosen law enforcement as a profession for excitement reasons. The second reason for both race categories was helping.

Hypothesis 4. No significant relationship will be found between female police officers' years of education and why they chose law enforcement as a profession. The distribution of responses and statistical results are presented in Table VIII.

TABLE VIII

\section{YEARS OF EDUCATION AND REASON FOR CHOOSING LAW ENFORCEMENT BY NUMBER AND PERCENT}

\begin{tabular}{|c|c|c|c|c|c|c|}
\hline \multirow[b]{3}{*}{ Reason } & \multicolumn{5}{|c|}{ Years of Education } & \multirow[b]{2}{*}{ Total } \\
\hline & $<=13$ & $>13<=14$ & $>14<=15$ & $>15<=16$ & $>16$ & \\
\hline & $\begin{array}{l}\text { Frequency } \\
\text { (percent) }\end{array}$ & $\begin{array}{l}\text { Frequency } \\
\text { (percent) }\end{array}$ & $\begin{array}{l}\text { Frequency } \\
\text { (percent) }\end{array}$ & $\begin{array}{l}\text { Frequency } \\
\text { (percent) }\end{array}$ & $\begin{array}{c}\text { Frequency } \\
\text { (percent) }\end{array}$ & $\begin{array}{c}\text { Frequency } \\
\text { (percent) }\end{array}$ \\
\hline Security & $\begin{array}{c}83 \\
(36.40)\end{array}$ & $\begin{array}{c}53 \\
(27.89) \\
\end{array}$ & $\begin{array}{c}27 \\
(30.68)\end{array}$ & $\begin{array}{c}29 \\
(16.76)\end{array}$ & $\begin{array}{c}14 \\
(16.47) \\
\end{array}$ & $\begin{array}{c}206 \\
(26.96) \\
\end{array}$ \\
\hline Helping & $\begin{array}{c}58 \\
(25.44)\end{array}$ & $\begin{array}{c}44 \\
(23.16) \\
\end{array}$ & $\begin{array}{c}17 \\
(19.32)\end{array}$ & $\begin{array}{c}46 \\
(26.59)\end{array}$ & $\begin{array}{c}27 \\
(31.76) \\
\end{array}$ & $\begin{array}{c}192 \\
(25.13)\end{array}$ \\
\hline Excitement & $\begin{array}{c}39 \\
(17.11)\end{array}$ & $\begin{array}{c}48 \\
(25.26)\end{array}$ & $\begin{array}{c}19 \\
(21.59)\end{array}$ & $\begin{array}{c}54 \\
(31.21)\end{array}$ & $\begin{array}{c}26 \\
(30.59) \\
\end{array}$ & $\begin{array}{c}186 \\
(24.35) \\
\end{array}$ \\
\hline Career Goal & $\begin{array}{c}29 \\
(12.71)\end{array}$ & $\begin{array}{c}23 \\
(12.11)\end{array}$ & $\begin{array}{c}12 \\
(13.64)\end{array}$ & $\begin{array}{c}13 \\
(7.51)\end{array}$ & $\begin{array}{c}3 \\
(3.53)\end{array}$ & $\begin{array}{c}80 \\
(10.47)\end{array}$ \\
\hline Other & $\begin{array}{c}19 \\
(8.33)\end{array}$ & $\begin{array}{c}22 \\
(11.58)\end{array}$ & $\begin{array}{c}13 \\
(14.77) \\
\end{array}$ & $\begin{array}{c}31 \\
(17.92) \\
\end{array}$ & $\begin{array}{c}15 \\
(17.65) \\
\end{array}$ & $\begin{array}{c}100 \\
(13.09) \\
\end{array}$ \\
\hline TOTAL & $\begin{array}{c}228 \\
(100,00)\end{array}$ & $\begin{array}{c}190 \\
(100.00)\end{array}$ & $\begin{array}{c}88 \\
(100.00)\end{array}$ & $\begin{array}{c}173 \\
(100.00)\end{array}$ & $\begin{array}{c}85 \\
(100.00)\end{array}$ & $\begin{array}{c}74 \\
(100.00)\end{array}$ \\
\hline
\end{tabular}

The null hypothesis is rejected. A chi square of $<26.3$ is required to retain the null hypothesis at the .05 level of significance with 16 degrees of freedom. The data 
suggest that lesser education appears to associate with security while higher education and helping appear to be associated.

Hypothesis 5. No significant relationship will be found between female police officers' socioeconomic status background and why they chose law enforcement as a profession. The distribution of responses and statistical results are presented in Table IX.

TABLE IX

SOCIOECONOMIC STATUS AND REASON FOR CHOOSING LAW
ENFORCEMENT BY NUMBER AND PERCENT

\begin{tabular}{|l|c|c|c|c|c||}
\hline \multirow{2}{*}{ Reason } & \multicolumn{4}{|c|}{ Socioeconomic Status } & \multirow{2}{*}{ Total } \\
\cline { 2 - 7 } & Lrequency & Percent & Frequency & Percent & $\begin{array}{c}\text { Frequency } \\
\text { (percent) }\end{array}$ \\
\cline { 2 - 7 } & 131 & 31.95 & 75 & 21.19 & $\begin{array}{c}206 \\
(26.92)\end{array}$ \\
\hline \hline Security & 102 & 24.88 & 90 & 25.42 & $\begin{array}{c}192 \\
(25.13)\end{array}$ \\
\hline Heiping & 89 & 21.71 & 97 & 27.40 & $\begin{array}{c}186 \\
(24.35)\end{array}$ \\
\hline Excitement & 43 & 10.49 & 37 & 10.45 & $\begin{array}{c}80 \\
(10.47)\end{array}$ \\
\hline Career Goal & 45 & 10.98 & 55 & 15.54 & $\begin{array}{c}100 \\
(13.09)\end{array}$ \\
\hline Other & 410 & 100.00 & 354 & 100.00 & $\begin{array}{c}764 \\
(100.00)\end{array}$ \\
\hline TOTAL & & & & & \\
\hline
\end{tabular}

$\chi^{2} 13.736 \quad$ df $=4 \quad P=0.008 \quad n=764$

The null hypothesis is rejected. A chi-square of $<9.49$ is required to retain the null hypothesis at the .05 level of significance with 4 degrees of freedom. These data suggest that female police officers with low socioeconomic status backgrounds chose law 
enforcement as a profession for security reasons. Female police officers from high socioeconomic backgrounds chose law enforcement for reasons of excitement.

Hypothesis 6. No significant relationship will be found between female police officers' marital status at the time of employment and why they chose law enforcement as a profession. The distribution of responses and statistical results are presented in Table X.

TABLE X

\section{ENTERING MARITAL STATUS AND REASON FOR CHOOSING LAW ENFORCEMENT BY NUMBER AND PERCENT}

\begin{tabular}{|c|c|c|c|c|c|}
\hline \multirow[b]{3}{*}{ Reason } & \multicolumn{4}{|c|}{ Marital Status } & \multirow[b]{2}{*}{ Total } \\
\hline & Single & Divorced & Married & Other & \\
\hline & $\begin{array}{c}\text { Frequency } \\
\text { (percent) }\end{array}$ & $\begin{array}{c}\text { Frequency } \\
\text { (percent) }\end{array}$ & $\begin{array}{c}\text { Frequency } \\
\text { (percent) }\end{array}$ & $\begin{array}{c}\text { Frequency } \\
\text { (percent) }\end{array}$ & $\begin{array}{c}\text { Frequency } \\
\text { (percent) }\end{array}$ \\
\hline Security & $\begin{array}{c}95 \\
(22.41)\end{array}$ & $\begin{array}{c}51 \\
(41.13)\end{array}$ & $\begin{array}{c}49 \\
(25.65)\end{array}$ & $\begin{array}{c}11 \\
(44.00)\end{array}$ & $\begin{array}{c}206 \\
(26.96)\end{array}$ \\
\hline Helping & $\begin{array}{c}102 \\
(24.06) \\
\end{array}$ & $\begin{array}{c}31 \\
(25.00) \\
\end{array}$ & $\begin{array}{c}53 \\
(27.75) \\
\end{array}$ & $\begin{array}{c}6 \\
(24.00) \\
\end{array}$ & $\begin{array}{c}192 \\
(25.13) \\
\end{array}$ \\
\hline Excitement & $\begin{array}{c}116 \\
(27.36) \\
\end{array}$ & $\begin{array}{c}26 \\
(20.97)\end{array}$ & $\begin{array}{c}39 \\
(20.42) \\
\end{array}$ & $\begin{array}{c}5 \\
(20.00) \\
\end{array}$ & $\begin{array}{c}186 \\
(24.35) \\
\end{array}$ \\
\hline Career Goal & $\begin{array}{c}49 \\
(11.56) \\
\end{array}$ & $\begin{array}{c}7 \\
(5.65) \\
\end{array}$ & $\begin{array}{c}23 \\
(12.04) \\
\end{array}$ & $\begin{array}{c}1 \\
(4.00) \\
\end{array}$ & $\begin{array}{c}80 \\
(10.47) \\
\end{array}$ \\
\hline Other & $\begin{array}{c}62 \\
(14.62) \\
\end{array}$ & $\begin{array}{c}9 \\
(7.26) \\
\end{array}$ & $\begin{array}{c}27 \\
(14.14) \\
\end{array}$ & $\begin{array}{c}2 \\
(8.00) \\
\end{array}$ & $\begin{array}{c}100 \\
(13.09) \\
\end{array}$ \\
\hline TOTAL & $\begin{array}{c}424 \\
(100.00)\end{array}$ & $\begin{array}{c}124 \\
(100.00)\end{array}$ & $\begin{array}{c}191 \\
(100.00)\end{array}$ & $\begin{array}{c}25 \\
(100.00)\end{array}$ & $\begin{array}{c}764 \\
(100.00)\end{array}$ \\
\hline
\end{tabular}

The null hypothesis is rejected. A chi-square of $<21.0$ is required to retain the null hypothesis at the .05 level of significance with 12 degrees of freedom. 
Of note in this analysis is that divorced, and women in the other category, appear to have chosen law enforcement for security reasons. Married women, on the other hand, chose law enforcement in order to be helping. Those women who were single viewed the excitement of the job as the predominant reason for choosing law enforcement as a profession.

Hypothesis 7. No significant relationship will be found between female police officers rank and their reasons for choosing law enforcement as a profession. The distribution of responses and statistical results are presented in Table XI.

TABLE XI

RANK AND REASON FOR CHOOSING LAW ENFORCEMENT BY NUMBER AND PERCENT

\begin{tabular}{|c|c|c|c|c|c|}
\hline \multirow{3}{*}{ Reason } & \multicolumn{4}{|c|}{ Rank } & \multirow[b]{2}{*}{ Total } \\
\hline & Officer & $\begin{array}{l}\text { Investigator } \\
\text { (detective! } \\
\text { agent) }\end{array}$ & $\begin{array}{l}\text { Supervisor } \\
\text { (corporal/ } \\
\text { sergeant) }\end{array}$ & $\begin{array}{c}\text { Staff } \\
\text { (lieutenant } \\
\text { and above) }\end{array}$ & \\
\hline & $\begin{array}{c}\text { Frequency } \\
\text { (percent) }\end{array}$ & $\begin{array}{c}\text { Frequency } \\
\text { (percent) }\end{array}$ & $\begin{array}{c}\text { Frequency } \\
\text { (percent) }\end{array}$ & $\begin{array}{c}\text { Frequency } \\
\text { (percent) }\end{array}$ & $\begin{array}{r}\text { Frequency } \\
\text { (percent) }\end{array}$ \\
\hline Security & $\begin{array}{c}133 \\
(26.33)\end{array}$ & $\begin{array}{c}22 \\
(26.51)\end{array}$ & $\begin{array}{c}34 \\
(29.82)\end{array}$ & $\begin{array}{c}12 \\
(27.27)\end{array}$ & $\begin{array}{c}201 \\
(26.87)\end{array}$ \\
\hline Helping & $\begin{array}{c}142 \\
(28.01)\end{array}$ & $\begin{array}{c}17 \\
(20.48)\end{array}$ & $\begin{array}{c}22 \\
(19.30) \\
\end{array}$ & $\begin{array}{c}8 \\
(18.18)\end{array}$ & $\begin{array}{c}189 \\
(25.27) \\
\end{array}$ \\
\hline Excitement & $\begin{array}{c}106 \\
(20.01)\end{array}$ & $\begin{array}{c}28 \\
(33.73)\end{array}$ & $\begin{array}{c}34 \\
(29.82)\end{array}$ & $\begin{array}{c}15 \\
(33.73) \\
\end{array}$ & $\begin{array}{c}183 \\
(24.47) \\
\end{array}$ \\
\hline Career Goal & $\begin{array}{c}71 \\
(14.00)\end{array}$ & $\begin{array}{c}2 \\
(6.02)\end{array}$ & $\begin{array}{c}1 \\
(1.75)\end{array}$ & $\begin{array}{c}5 \\
(2.27)\end{array}$ & $\begin{array}{c}79 \\
(10.56) \\
\end{array}$ \\
\hline Other & $\begin{array}{c}55 \\
(10.85) \\
\end{array}$ & $\begin{array}{c}11 \\
(13.25)\end{array}$ & $\begin{array}{c}22 \\
(19.30)\end{array}$ & $\begin{array}{c}8 \\
(18.18) \\
\end{array}$ & $\begin{array}{c}96 \\
(12.83) \\
\end{array}$ \\
\hline TOTAL & $\begin{array}{c}507 \\
(100.00)\end{array}$ & $\begin{array}{c}83 \\
(100.00)\end{array}$ & $\begin{array}{c}114 \\
(100.00)\end{array}$ & $\begin{array}{c}44 \\
(100.00)\end{array}$ & $\begin{array}{c}748 \\
(100.00)\end{array}$ \\
\hline
\end{tabular}


The null hypothesis is rejected. A chi-square value $<21.026$ is required to retain the null hypothesis at the .05 level of significance with 12 degrees of freedom.

The data reflect that the reason of excitement appears to be most prominent among investigators and those in higher ranks (staff). Among first line supervisors, career goal appears to the least frequent reason for choosing law enforcement as a profession.

Hypothesis 8. No significant relationship will be found between female police officers' college major and why they choose law enforcement as a profession. The distribution of responses and statistical results are presented in Table XII.

TABLE XII

COLLEGE MAJOR AND REASON FOR CHOOSING LAW ENFORCEMENT BY NUMBER AND PERCENT

\begin{tabular}{|c|c|c|c|c|c|c|c|}
\hline \multirow{3}{*}{ Reason } & \multicolumn{6}{|c|}{ College Major } & \multirow[b]{2}{*}{ Total } \\
\hline & Humanities & $\begin{array}{l}\text { Social } \\
\text { Science }\end{array}$ & Science & $\begin{array}{l}\text { Criminal } \\
\text { Justice }\end{array}$ & Vocational & None & \\
\hline & $\begin{array}{c}\text { Frequency } \\
\text { (percent) }\end{array}$ & $\begin{array}{c}\text { Frequency } \\
\text { (percent) }\end{array}$ & $\begin{array}{c}\text { Frequency } \\
\text { (percent) }\end{array}$ & $\begin{array}{l}\text { Frequency } \\
\text { (percent) }\end{array}$ & $\begin{array}{c}\text { Frequency } \\
\text { (percent) }\end{array}$ & $\begin{array}{l}\text { Frequency } \\
\text { (percent) }\end{array}$ & $\begin{array}{l}\text { Frequency } \\
\text { (percent) }\end{array}$ \\
\hline Security & $\begin{array}{c}22 \\
(26.83)\end{array}$ & $\begin{array}{c}56 \\
(29.47)\end{array}$ & $\begin{array}{c}16 \\
(30.77)\end{array}$ & $\begin{array}{c}42 \\
(15.44)\end{array}$ & $\begin{array}{c}8 \\
(36.36)\end{array}$ & $\begin{array}{c}54 \\
(44.26)\end{array}$ & $\begin{array}{c}198 \\
(26.76)\end{array}$ \\
\hline Helping & $\begin{array}{c}17 \\
(20.73)\end{array}$ & $\begin{array}{c}50 \\
(26.32)\end{array}$ & $\begin{array}{c}16 \\
(30.77)\end{array}$ & $\begin{array}{c}72 \\
(26.47)\end{array}$ & $\begin{array}{c}3 \\
(13.64)\end{array}$ & $\begin{array}{c}27 \\
(22.13)\end{array}$ & $\begin{array}{c}185 \\
(25.00)\end{array}$ \\
\hline $\begin{array}{l}\text { Excite- } \\
\text { ment }\end{array}$ & $\begin{array}{c}24 \\
(29.27)\end{array}$ & $\begin{array}{c}46 \\
(24.21)\end{array}$ & $\begin{array}{c}9 \\
(17.31)\end{array}$ & $\begin{array}{c}80 \\
(29.41)\end{array}$ & $\begin{array}{c}3 \\
(13.64)\end{array}$ & $\begin{array}{c}19 \\
(15.57)\end{array}$ & $\begin{array}{c}181 \\
(24.46)\end{array}$ \\
\hline $\begin{array}{l}\text { Career } \\
\text { Goal }\end{array}$ & $\begin{array}{c}6 \\
(7.32)\end{array}$ & $\begin{array}{c}16 \\
(8.42)\end{array}$ & $\begin{array}{c}5 \\
(9.62)\end{array}$ & $\begin{array}{c}36 \\
(13.24)\end{array}$ & $\begin{array}{c}3 \\
(13.64)\end{array}$ & $\begin{array}{c}13 \\
(10.66) \\
\end{array}$ & $\begin{array}{c}79 \\
(10.68) \\
\end{array}$ \\
\hline Other & $\begin{array}{c}13 \\
(15.85)\end{array}$ & $\begin{array}{c}22 \\
(11.58)\end{array}$ & $\begin{array}{c}6 \\
(11.54)\end{array}$ & $\begin{array}{c}42 \\
(15.44)\end{array}$ & $\begin{array}{c}5 \\
(22.73)\end{array}$ & $\begin{array}{c}9 \\
(7.38)\end{array}$ & $\begin{array}{c}97 \\
(13.11)\end{array}$ \\
\hline Total & $\begin{array}{c}82 \\
(100.00)\end{array}$ & $\begin{array}{c}190 \\
(100.00)\end{array}$ & $\begin{array}{c}52 \\
(100.00)\end{array}$ & $\begin{array}{c}272 \\
(100.00)\end{array}$ & $\begin{array}{c}22 \\
(100.00)\end{array}$ & $\begin{array}{c}122 \\
(100.00)\end{array}$ & $\begin{array}{c}740 \\
(100.00)\end{array}$ \\
\hline
\end{tabular}

$$
x^{2} 51.690 \quad \text { df }=20 \quad P=0.000 \quad n=740
$$


The null hypothesis is rejected. A chi-square value $<31.010$ is required to retain the null hypothesis at the .05 level of significance with 20 degrees of freedom.

The data suggest that security appears to be the reason of choice for those whose college majors were in the social sciences, sciences, and vocational areas, while excitement was the most prominent reason for female police officers with humanities and no college majors.

\section{JOB SATISFACTION AND MORALE}

It has been reported that police work is traditionally viewed, however incorrectly, as a natural occupation for males (Talarico and Swanson, 1982). Women who are employed in a nontraditional working environment, such as police work, experience varying degrees of anxiety associated with assimilation into the occupational role. The dynamics of their assimilation may be manifested in attitudes about their work and evaluated in terms of their job satisfaction.

Mcllwee (1982) suggests assimilation into a traditionally male-dominated occupation is a two-phase process: during the first year, concentration is on status issues which are resolved through developing self-confidence, mastering skills, and getting along with colleagues; during the second year, there is less concern about status in the maledominated occupation, and more concern about job satisfaction/dissatisfaction issues such as pay, and working conditions. Hulin and Smith (1964) reported that gender is not a crucial factor in the determination of job satisfaction. However, it is important to look at the relationship of gender to all other occupation variables, i.e., over/under utilization of skills and an equitable reward system (intrinsic and extrinsic). 
Job satisfaction is thought of, in the classic sense, as the difference between what an individual expects from their work and what they experience (Morse, 1953; Summers, 1988). Expectation and experience may be moderated by the socio-demographic characteristics of the worker.

The 759 female police officers who constituted this study population had a mean score of 34.478 on the Morse Job Satisfaction and Morale Index. The mean score of the index is 27.5 which indicates that these respondents were satisfied with their jobs. This finding is consistent with Perlstein's (1971) research. However, like Perlstein, these findings contradict those reported by Niederhoffer (1967), which reported a high level of job dissatisfaction among the male officers he studied.

\section{Proposition 2}

It is expected that the background characteristics of female police officers will be related to their scores on the Job Satisfaction and Morale Index.

Hypothesis 9. No significant relationship will be found between female police officers' age and their Job Satisfaction and Morale Index scores. The test for this hypothesis consisted of computing a product-moment correlation coefficient for the age of the female police officers and their scores on the Job Satisfaction and Morale Index. An $r$ of $0.003(P=0.935)$ was obtained. This finding suggested that attempting to explain the variations in job satisfaction and morale scores with the age of the female police officer is not very useful (see matrix at Appendix E).

Hypothesis 10. No significant relationship will be found between female police officers' religion and their scores on the Job Satisfaction and Morale Index. The Index 
scores were divided at the mean (34.478) to differentiate between high and low. The distribution of responses and statistical results are presented in Table XIII.

TABLE XIII

RELIGION, AND JOB SATISFACTION AND MORALE BY NUMBER AND PERCENT

\begin{tabular}{||l|c|c|c|c||}
\hline \multirow{2}{*}{$\begin{array}{l}\text { Job Satisfaction } \\
\text { and Morale }\end{array}$} & Catholic & Protestant & Other & Totai \\
\cline { 2 - 5 } & $\begin{array}{c}\text { Frequency } \\
\text { (percent) }\end{array}$ & $\begin{array}{c}\text { Frequency } \\
\text { (percent) }\end{array}$ & $\begin{array}{c}\text { Frequency } \\
\text { (percent) }\end{array}$ & $\begin{array}{c}\text { Frequency } \\
\text { (percent) }\end{array}$ \\
\hline \hline High & $\begin{array}{c}166 \\
(56.27)\end{array}$ & $\begin{array}{c}188 \\
(52.66)\end{array}$ & $\begin{array}{c}29 \\
(53.70)\end{array}$ & $\begin{array}{c}383 \\
(54.25)\end{array}$ \\
\hline Low & $\begin{array}{c}129 \\
(43.73)\end{array}$ & $\begin{array}{c}169 \\
(47.34)\end{array}$ & $\begin{array}{c}25 \\
(46.30)\end{array}$ & $\begin{array}{c}323 \\
(45.75)\end{array}$ \\
\hline TOTAL & $\begin{array}{c}295 \\
(100.00)\end{array}$ & $\begin{array}{c}357 \\
(100.00)\end{array}$ & $\begin{array}{c}54 \\
(100.00)\end{array}$ & $\begin{array}{c}706 \\
(100.00)\end{array}$ \\
\hline
\end{tabular}

$$
x^{2} 0.855 \quad \text { df }=2 \quad P=0.652 \quad n=706
$$

The null hypothesis is retained. A chi-square value $>5.99$ is required to reject the null hypothesis at the .05 level of significance with 2 degrees of freedom. The data reflect that all religious categories appear to be satisfied with their jobs.

Hypothesis 11. No significant relationship will be found between female police officers' race and their Job Satisfaction and Morale Index scores. The distribution of responses and statistical results are presented in Table XIV. 
TABLE XIV

\section{RACE, AND JOB SATISFACTION AND MORALE BY NUMBER AND PERCENT}

\begin{tabular}{||c|c|c|c|}
\hline \multirow{4}{*}{$\begin{array}{l}\text { Job Satisfaction and } \\
\text { Morale }\end{array}$} & White & Women of Color & \multirow{2}{*}{ Total } \\
\cline { 2 - 4 } & $\begin{array}{c}\text { Frequency } \\
\text { (percent) }\end{array}$ & $\begin{array}{c}\text { Frequency } \\
\text { (percent) }\end{array}$ & $\begin{array}{c}\text { Frequency } \\
\text { (percent) }\end{array}$ \\
\cline { 2 - 4 } & $\begin{array}{c}289 \\
(52.93)\end{array}$ & $\begin{array}{c}124 \\
(54.63)\end{array}$ & $\begin{array}{c}413 \\
(53.43)\end{array}$ \\
\hline \hline High & $\begin{array}{c}257 \\
(47.07)\end{array}$ & $\begin{array}{c}103 \\
(45.37)\end{array}$ & $\begin{array}{c}360 \\
(46.57)\end{array}$ \\
\hline Low & $\begin{array}{c}546 \\
(100.00)\end{array}$ & $\begin{array}{c}227 \\
(100.00)\end{array}$ & $\begin{array}{c}773 \\
(100.00)\end{array}$ \\
\hline TOTAL & & & \\
\hline
\end{tabular}

$$
x^{2} 0.185 \quad \text { df }=1 \quad P=0.667 \quad n=773
$$

The null hypothesis is retained. A chi-square of $>3.84$ is required to reject the null hypothesis at the .05 level of significance with 1 degree of freedom. The data suggest that female police officers, regardless of race, are more satisfied than dissatisfied.

Hypothesis 12. No significant relationship will be found between female police officers' years of education and their scores on the Job Satisfaction and Morale Index. The distribution of resuits and statistical analysis are presented in Table XV. 
TABLE XV

YEARS OF EDUCATION, AND JOB SATISFACTION AND MORALE BY NUMBER AND PERCENT

\begin{tabular}{|c|c|c|c|c|c|c|}
\hline \multirow{3}{*}{$\begin{array}{l}\text { Job } \\
\text { Satisfaction } \\
\text { and Morale }\end{array}$} & \multicolumn{5}{|c|}{ Years of Education } & \multirow[b]{2}{*}{ Total } \\
\hline & $<=13$ & $>13<=14$ & $>14<=15$ & $>15<=16$ & $>16$ & \\
\hline & $\begin{array}{l}\text { Frequency } \\
\text { (percent) }\end{array}$ & $\begin{array}{l}\text { Frequency } \\
\text { (percenl) }\end{array}$ & $\begin{array}{l}\text { Frequency } \\
\text { (percent) }\end{array}$ & $\begin{array}{l}\text { Frequency } \\
\text { (percent) }\end{array}$ & $\begin{array}{l}\text { Frequency } \\
\text { (percent) }\end{array}$ & $\begin{array}{l}\text { Frequency } \\
\text { (percent) }\end{array}$ \\
\hline High & $\begin{array}{c}125 \\
(52.74)\end{array}$ & $\begin{array}{c}102 \\
(5204)\end{array}$ & $\begin{array}{c}49 \\
(55.06)\end{array}$ & $\begin{array}{c}92 \\
(52.27)\end{array}$ & $\begin{array}{c}51 \\
(59.30)\end{array}$ & $\begin{array}{c}419 \\
(53.44)\end{array}$ \\
\hline Low & $\begin{array}{c}112 \\
(47.26)\end{array}$ & $\begin{array}{c}94 \\
(47.96)\end{array}$ & $\begin{array}{c}40 \\
(44.94)\end{array}$ & $\begin{array}{c}84 \\
(47.73)\end{array}$ & $\begin{array}{c}35 \\
(40.70)\end{array}$ & $\begin{array}{c}365 \\
(46.56)\end{array}$ \\
\hline TOTAL & $\begin{array}{c}237 \\
(100.00)\end{array}$ & $\begin{array}{c}196 \\
(100.00)\end{array}$ & $\begin{array}{c}89 \\
(100.00)\end{array}$ & $\begin{array}{c}176 \\
(100.00)\end{array}$ & $\begin{array}{c}86 \\
(100.00)\end{array}$ & $\begin{array}{c}784 \\
(100.00)\end{array}$ \\
\hline
\end{tabular}

The null hypothesis is retained. A chi-square of $>9.49$ is required to reject the null hypothesis at the .05 level of significance with 4 degrees of freedom.

Hypothesis 13. No significant relationship will be found between female police officers' socioeconomic status background and their scores on the Job Satisfaction and Morale Index.

The test for this hypothesis consisted of computing a product-moment correlation coefficient for the socioeconomic status background (TSEI) of the female police officers and their job satisfaction and morale scores. The null hypothesis is retained. An $r$ of $0.051(P=0.201)$ was obtained. The finding suggests that the variable of socioeconomic status background is not very useful in attempting to explain the variations in job satisfaction and morale scores among the female police officers in this study (see matrix at Appendix E). 
Hypothesis 14. No significant relationship will be found between female police officers' tenure and their Job Satisfaction and Morale Index scores (test: product-moment correlation coefficient).

The test for this hypothesis consisted of computing a product-moment correlation coefficient for female police officers' tenure and scores on the Job Satisfaction and Morale Index.

The null hypothesis is retained. An $r$ of $-0.015(P=0.712)$ was obtained. The data suggest that the variable of tenure is not very useful in explaining job satisfaction and morale (see matrix at Appendix E).

Hypothesis 15. No significant relationship will be found between female police officers' marital status and their Job Satisfaction and Morale Index scores. The distribution of responses and statistical results are presented in Table XVI.

TABLE XVI

MARITAL STATUS, AND JOB SATISFACTION AND MORALE BY NUMBER AND PERCENT

\begin{tabular}{|c|c|c|c|c|c|c|}
\hline \multirow{3}{*}{$\begin{array}{l}\text { Job } \\
\text { Satisfaction } \\
\text { and Morale }\end{array}$} & \multicolumn{5}{|c|}{ Marital Status } & \multirow[b]{2}{*}{ Total } \\
\hline & Single & Divorced & Married & Other & $\begin{array}{l}\text { Spouse in CJ } \\
\text { Sysiem }\end{array}$ & \\
\hline & $\begin{array}{l}\text { Frequency } \\
\text { (percent) }\end{array}$ & $\begin{array}{l}\text { Frequency } \\
\text { (percent) }\end{array}$ & $\begin{array}{l}\text { Frequency } \\
\text { (percent) }\end{array}$ & $\begin{array}{l}\text { Frequency } \\
\text { (percent) }\end{array}$ & $\begin{array}{l}\text { Frequency } \\
\text { (percent) }\end{array}$ & $\begin{array}{c}\text { Frequency } \\
\text { (percent) }\end{array}$ \\
\hline High & $\begin{array}{c}144 \\
(53.33)\end{array}$ & $\begin{array}{c}85 \\
(51.83)\end{array}$ & $\begin{array}{c}76 \\
(58.91)\end{array}$ & $\begin{array}{c}15 \\
(53.57)\end{array}$ & $\begin{array}{c}99 \\
(51.30)\end{array}$ & $\begin{array}{c}419 \\
(53.44)\end{array}$ \\
\hline Low & $\begin{array}{c}126 \\
(46.67)\end{array}$ & $\begin{array}{c}79 \\
(48.17)\end{array}$ & $\begin{array}{c}53 \\
(41.09)\end{array}$ & $\begin{array}{c}13 \\
(46.43)\end{array}$ & $\begin{array}{c}94 \\
(48.70) \\
\end{array}$ & $\begin{array}{c}365 \\
(46.56) \\
\end{array}$ \\
\hline TOTAL & $\begin{array}{c}270 \\
(100.00)\end{array}$ & $\begin{array}{c}164 \\
(100.00)\end{array}$ & $\begin{array}{c}129 \\
(100.00)\end{array}$ & $\begin{array}{c}28 \\
(100.00)\end{array}$ & $\begin{array}{c}193 \\
(100.00)\end{array}$ & $\begin{array}{c}784 \\
(100.00)\end{array}$ \\
\hline
\end{tabular}


The null hypothesis is retained. A chi-square of $>9.49$ is required to reject the null hypothesis at the .05 level of significance with 4 degrees of freedom. The data reflect that female police officers are satisfied with their jobs, regardless of their marital status.

Hypothesis 16. No significant relationship will be found between the type of work female police officers perform and their Job Satisfaction and Morale Index scores. The distribution of responses and statistical results are presented in Table XVII.

\section{TABLE XVII}

TYPE OF WORK, AND JOB SATISFACTION AND MORALE BY NUMBER AND PERCENT

\begin{tabular}{|c|c|c|c|c|c|c|}
\hline \multirow{3}{*}{$\begin{array}{l}\text { Job } \\
\text { Satisfaction } \\
\text { and Morale }\end{array}$} & \multicolumn{5}{|c|}{ Type of Work } & \multirow[b]{2}{*}{ Total } \\
\hline & $\begin{array}{l}\text { "Protect and } \\
\text { Serve" }\end{array}$ & Investigation & Enforcement & $\begin{array}{l}\text { Administra- } \\
\text { tion }\end{array}$ & Other & \\
\hline & $\begin{array}{l}\text { Frequency } \\
\text { (percent) }\end{array}$ & $\begin{array}{l}\text { Frequency } \\
\text { (percent) }\end{array}$ & $\begin{array}{l}\text { Frequency } \\
\text { (percent) }\end{array}$ & $\begin{array}{l}\text { Frequency } \\
\text { (percent) }\end{array}$ & $\begin{array}{l}\text { Frequency } \\
\text { (percent) }\end{array}$ & $\begin{array}{c}\text { Frequency } \\
\text { (percent) }\end{array}$ \\
\hline High & $\begin{array}{c}276 \\
(54.33)\end{array}$ & $\begin{array}{c}45 \\
(65.22)\end{array}$ & $\begin{array}{c}51 \\
(45.13)\end{array}$ & $\begin{array}{c}20 \\
(62.50)\end{array}$ & $\begin{array}{c}13 \\
(59.09)\end{array}$ & $\begin{array}{c}405 \\
(54.44)\end{array}$ \\
\hline Low & $\begin{array}{c}232 \\
(45.67)\end{array}$ & $\begin{array}{c}24 \\
(34.78)\end{array}$ & $\begin{array}{c}62 \\
(54.87)\end{array}$ & $\begin{array}{c}12 \\
(37.50)\end{array}$ & $\begin{array}{c}9 \\
(40.91)\end{array}$ & $\begin{array}{c}339 \\
(45.56)\end{array}$ \\
\hline TOTAL & $\begin{array}{c}508 \\
(100.00)\end{array}$ & $\begin{array}{c}69 \\
(100.00)\end{array}$ & $\begin{array}{c}113 \\
(100.00)\end{array}$ & $\begin{array}{c}32 \\
(100.00)\end{array}$ & $\begin{array}{c}22 \\
(100.00)\end{array}$ & $\begin{array}{c}744 \\
(100.00)\end{array}$ \\
\hline
\end{tabular}

The null hypothesis is retained. A chi-square of $>9.49$ is required to reject the null hypothesis at the .05 level of significance with 4 degrees of freedom. While the differences are not statistically significant, the data suggest that female police officers appear to be generally more satisfied than not, except when their duty involves enforcement. 
Hypothesis 17. No significant relationship will be found between female police officers' college major and their Job Satisfaction and Morale Index scores. The distribution of responses and statistical results are presented in Table XVIII.

TABLE XVIII

COLLEGE MAJOR, AND JOB SATISFACTION AND MORALE BY NUMBER AND PERCENT

\begin{tabular}{|c|c|c|c|c|c|c|c|}
\hline \multirow{3}{*}{$\begin{array}{l}\text { Job Satis- } \\
\text { faction and } \\
\text { Morale }\end{array}$} & \multicolumn{6}{|c|}{ College Major } & \multirow[b]{2}{*}{ Total } \\
\hline & Humanities & $\begin{array}{c}\text { Social } \\
\text { Science }\end{array}$ & Science & $\begin{array}{c}\text { Criminal } \\
\text { Justice }\end{array}$ & Vocational & None & \\
\hline & $\begin{array}{l}\text { Frequency } \\
\text { (percent) }\end{array}$ & $\begin{array}{l}\text { Frequency } \\
\text { (percent) }\end{array}$ & $\begin{array}{c}\text { Frequency } \\
\text { (percent) }\end{array}$ & $\begin{array}{l}\text { Frequency } \\
\text { (percent) }\end{array}$ & $\begin{array}{l}\text { Frequency } \\
\text { (percent) }\end{array}$ & $\begin{array}{c}\text { Frequency } \\
\text { (percent) }\end{array}$ & $\begin{array}{c}\text { Frequency } \\
\text { (percent) }\end{array}$ \\
\hline High & $\begin{array}{c}49 \\
(59.04)\end{array}$ & $\begin{array}{c}106 \\
(54.36)\end{array}$ & $\begin{array}{c}30 \\
(57.69)\end{array}$ & $\begin{array}{c}142 \\
(50.90)\end{array}$ & $\begin{array}{c}12 \\
(54.55)\end{array}$ & $\begin{array}{c}65 \\
(50.39)\end{array}$ & $\begin{array}{c}404 \\
(53.16)\end{array}$ \\
\hline Low & $\begin{array}{c}34 \\
(40.96)\end{array}$ & $\begin{array}{c}89 \\
(45.64)\end{array}$ & $\begin{array}{c}22 \\
(42.31)\end{array}$ & $\begin{array}{c}137 \\
(49.10)\end{array}$ & $\begin{array}{c}10 \\
(45.45)\end{array}$ & $\begin{array}{c}64 \\
(49.61)\end{array}$ & $\begin{array}{c}356 \\
(46.84)\end{array}$ \\
\hline TOTAL & $\begin{array}{c}83 \\
(100.00)\end{array}$ & $\begin{array}{c}195 \\
(100.00)\end{array}$ & $\begin{array}{c}52 \\
(100.00)\end{array}$ & $\begin{array}{c}279 \\
(100.00)\end{array}$ & $\begin{array}{c}22 \\
(100.00)\end{array}$ & $\begin{array}{c}129 \\
(100.00)\end{array}$ & $\begin{array}{c}7600 \\
(100.00)\end{array}$ \\
\hline
\end{tabular}

The null hypothesis is retained. A chi-square value $>11.070$ is required to reject the null hypothesis at the .05 level of significance with 5 degrees of freedom. The data suggest that those female police officers whose studies were in the humanities appear to be the most satisfied.

Hypothesis 18. No significant relationship will be found between the female police officers' rank and their Job Satisfaction and Morale Index scores. The distribution of responses and the statistical results are presented in Table XIX. 
TABLE XIX

RANK, AND JOB SATISFACTION AND MORALE BY NUMBER AND PERCENT

\begin{tabular}{||c|c|c|c|c|c||}
\hline \multirow{4}{*}{$\begin{array}{l}\text { Job } \\
\text { Satisfaction } \\
\text { and Morale }\end{array}$} & Officer & $\begin{array}{c}\text { Investigator } \\
\text { (detective/ } \\
\text { agent) }\end{array}$ & $\begin{array}{c}\text { Supervisor } \\
\text { (corporal/ } \\
\text { sergeant) }\end{array}$ & $\begin{array}{c}\text { Staff } \\
\text { (lieutenant } \\
\text { and above) }\end{array}$ & Total \\
\cline { 2 - 6 } & $\begin{array}{c}\text { Frequency } \\
\text { (percent) }\end{array}$ & $\begin{array}{c}\text { Frequency } \\
\text { (percent) }\end{array}$ & $\begin{array}{c}\text { Frequency } \\
\text { (percent) }\end{array}$ & $\begin{array}{c}\text { Frequency } \\
\text { (percent) }\end{array}$ & $\begin{array}{c}\text { Frequency } \\
\text { (percent) }\end{array}$ \\
\hline \hline High & $\begin{array}{c}260 \\
(49.81)\end{array}$ & $\begin{array}{c}54 \\
(62.79)\end{array}$ & $\begin{array}{c}62 \\
(53.91)\end{array}$ & $\begin{array}{c}32 \\
(71.11)\end{array}$ & $\begin{array}{c}408 \\
(53.13)\end{array}$ \\
\hline Low & $\begin{array}{c}262 \\
(50.19)\end{array}$ & $\begin{array}{c}32 \\
(37.21)\end{array}$ & $\begin{array}{c}53 \\
(46.09)\end{array}$ & $\begin{array}{c}13 \\
(28.91)\end{array}$ & $\begin{array}{c}360 \\
(46.88)\end{array}$ \\
\hline TOTAL & $\begin{array}{c}522 \\
(100.00)\end{array}$ & $\begin{array}{c}86 \\
(100.00)\end{array}$ & $\begin{array}{c}115 \\
(100.00)\end{array}$ & $\begin{array}{c}45 \\
(100.00)\end{array}$ & $\begin{array}{c}768 \\
(100.00)\end{array}$ \\
\hline
\end{tabular}

$x^{2} 11.407 \quad$ df $=3 \quad P=0.010 \quad n=768$

The null hypothesis is rejected. A chi square value of $<7.815$ is required to retain the null hypothesis at the 0.5 level of significance with 3 degrees of freedom. The data suggest that as female police officers advance in rank there is also an increase in their job satisfaction.

\section{ANOMIA}

This section will present the analysis of certain background characteristics of female police officers and their degree of anomia. Anomia has been described as "self-to-others alienation, a lack of interpersonal integration. A perspective of being mastered by threatening forces beyond one's control" (McDill, 1961, p. 244). Srole (1956) 
reported that anomia is on one end of a continuum of "self-to-others belongingness," with "self-to-others distance" (alienation) at the other (Meier and Bell, 1959).

It has been reported that a possible cause of anomia may be an individual's differential access to a means of achievement of goals (Meier and Bell, 1959; Rhodes, 1964). Opportunities for women to become police officers have been improving, albeit somewhat slowly. If Meier's and Rhodes' theory is correct, the fact of employment alone may mediate against higher anomia scores. If not, then issues such as length of service and the type of duty that female police officers perform may play a role.

The research on anomia in police officers is limited. There are, however, three studies which appear to have explored the phenomena in sufficient depth to be used for comparison. The first is Niederhoffer's (1967) study in which he reported that male police officer recruits were high in anomia. Bayley and Mendelsohn's (1968) study reported that the male police officers in their study were not anomic. Perlstein's (1971) study of female police officers also reported a nonanomic population.

The significance of these studies relates to the difference in populations upon which their conclusions are based. The increased number of women and their integration into the full range of police duties necessitates another examination of anomia and female police officers. The independent variables employed by Perlstein (1971) were used in the present study.

Other researchers have commented on the relationship of certain background characteristics and anomia. According to Rhodes (1964), education and socioeconomic status are inversely related to anomia. Bartol (1982) suggested that high performers may be anomic, because they are different and do not "fit into the police group." McDill 
(1961) found that education and occupation of head of household are most highly related to anomia.

The Srole Anomia Scale was employed in this study and has a mean score of 12.5 (Srole, 1956). In the present research, the author used the population scale mean (13.813) to differentiate between high and low anomia. The lower score is associated with a lesser degree of anomia.

\section{Proposition 3}

The female police officers' background characteristics can be expected to be related to their degree of anomia.

Hypothesis 19. No significant relationship will be found between female police officers' age and their degree of anomia. The test of this hypothesis consisted of computing the product-moment correlation coefficient.

The null hypothesis is retained. An $r$ of $-0.143(P=0.000)$ was obtained, which indicates a weak relationship. This finding suggests that the variable of age is of modest value in attempting to explain the variations in the degree of anomia among the female police officers studied (see matrix at Appendix E).

Hypothesis 20. No significant relationship will be found between female police officers' religion and their degree of anomia. The distribution of responses and statistical results are presented in Table $\mathbf{X X}$. 
TABLE XX

RELIGION AND DEGREE OF ANOMIA BY NUMBER AND PERCENT

\begin{tabular}{|c|c|c|c|c|}
\hline \multirow[b]{3}{*}{ Anomia } & \multicolumn{3}{|c|}{ Religion } & \multirow[b]{2}{*}{ Total } \\
\hline & Protestant & Catholic & Other & \\
\hline & $\begin{array}{c}\text { Frequency } \\
\text { (percent) }\end{array}$ & $\begin{array}{c}\text { Frequency } \\
\text { (percent) }\end{array}$ & $\begin{array}{c}\text { Frequency } \\
\text { (percent) }\end{array}$ & $\begin{array}{c}\text { Frequency } \\
\text { (percent) }\end{array}$ \\
\hline High & $\begin{array}{c}134 \\
(45.42)\end{array}$ & $\begin{array}{c}183 \\
(51.26)\end{array}$ & $\begin{array}{c}27 \\
(50.00)\end{array}$ & $\begin{array}{r}334 \\
(48.73) \\
\end{array}$ \\
\hline Low & $\begin{array}{c}161 \\
(54.58)\end{array}$ & $\begin{array}{c}174 \\
(48.74)\end{array}$ & $\begin{array}{c}27 \\
(50.00)\end{array}$ & $\begin{array}{c}362 \\
(51.27) \\
\end{array}$ \\
\hline TOTAL & $\begin{array}{c}295 \\
(100.00)\end{array}$ & $\begin{array}{c}357 \\
(100.00)\end{array}$ & $\begin{array}{c}54 \\
(100.00)\end{array}$ & $\begin{array}{c}706 \\
(100.00)\end{array}$ \\
\hline
\end{tabular}

$\begin{array}{llll}\chi^{2} 2.241 & \mathrm{df}=2 & \mathrm{P}=0.326 & \mathrm{n}=706\end{array}$

The null hypothesis is retained. A chi-square of $>5.99$ is required to reject the null hypothesis at the .05 level of significance with 2 degrees of freedom.

Hypothesis 21. No significant relationship will be found between female police officers' race and their degree of anomia. The distribution of responses and statistical results are presented in Table XXI. 
TABLE XXI

\section{RACE AND DEGREE OF ANOMIA} BY NUMBER AND PERCENT

\begin{tabular}{|c|c|c|c|c|c|}
\hline \multirow[b]{3}{*}{ Anomia } & \multicolumn{4}{|c|}{ Race } & \multirow{3}{*}{$\frac{\text { Total }}{\begin{array}{c}\text { Frequency } \\
\text { (percent) }\end{array}}$} \\
\hline & \multicolumn{2}{|c|}{ White } & \multicolumn{2}{|c|}{ Women of Color } & \\
\hline & Frequency & Percent & Frequency & Percent & \\
\hline High & 248 & 45.42 & 135 & 59.47 & $\begin{array}{c}383 \\
(49.55) \\
\end{array}$ \\
\hline Low & 298 & 54.58 & 92 & 40.35 & $\begin{array}{c}390 \\
(50.45)\end{array}$ \\
\hline TOTAL & 546 & 100.00 & 227 & 100.00 & $\begin{array}{c}773 \\
(100.00)\end{array}$ \\
\hline
\end{tabular}

$$
x^{2} 12.662 \quad \text { df }=1 \quad P=0.000 \quad n=773
$$

The null hypothesis is rejected. A chi-square of $<5.99$ is required to retain the null hypothesis at the .05 level of significance with 2 degrees of freedom. The groupings (high and low anomia) appear to be evenly split. The data suggest, however, that Women of Color are higher in anomia than Whites.

Hypothesis 22. No significant relationship will be found between female police officers' years of education and their degree of anomia. The distribution of responses and statistical results are presented in Table XXII. 
TABLE XXII

YEARS OF EDUCATION AND DEGREE OF ANOMIA BY NUMBER AND PERCENT

\begin{tabular}{|c|c|c|c|c|c|c|}
\hline \multirow[b]{3}{*}{ Anomia } & \multicolumn{5}{|c|}{ Years of Education } & \multirow[b]{2}{*}{ Total } \\
\hline & $<=13$ & $>13<=14$ & $>14<=15$ & $>15<=16$ & $>16$ & \\
\hline & $\begin{array}{c}\text { Frequency } \\
\text { (percent) }\end{array}$ & $\begin{array}{l}\text { Frequency } \\
\text { (percent) }\end{array}$ & $\begin{array}{l}\text { Frequency } \\
\text { (percent) }\end{array}$ & $\begin{array}{l}\text { Frequency } \\
\text { (percent) }\end{array}$ & $\begin{array}{l}\text { Frequency } \\
\text { (percent) }\end{array}$ & $\begin{array}{l}\text { Frequency } \\
\text { (percent) }\end{array}$ \\
\hline High & $\begin{array}{c}137 \\
(57.81)\end{array}$ & $\begin{array}{c}106 \\
(54.08)\end{array}$ & $\begin{array}{c}42 \\
(47.19)\end{array}$ & $\begin{array}{c}71 \\
(40.34)\end{array}$ & $\begin{array}{c}32 \\
(37.21)\end{array}$ & $\begin{array}{c}388 \\
(49.49)\end{array}$ \\
\hline Low & $\begin{array}{c}100 \\
(42.19)\end{array}$ & $\begin{array}{c}90 \\
(45.92)\end{array}$ & $\begin{array}{c}47 \\
(52.81)\end{array}$ & $\begin{array}{c}105 \\
(59.66)\end{array}$ & $\begin{array}{c}54 \\
(62.79)\end{array}$ & $\begin{array}{c}396 \\
(50.51)\end{array}$ \\
\hline TOTAL & $\begin{array}{c}237 \\
(100.00)\end{array}$ & $\begin{array}{c}196 \\
(100.00)\end{array}$ & $\begin{array}{c}89 \\
(100.00)\end{array}$ & $\begin{array}{c}176 \\
(100.00)\end{array}$ & $\begin{array}{c}86 \\
(100.00)\end{array}$ & $\begin{array}{c}784 \\
(100.00)\end{array}$ \\
\hline
\end{tabular}

$$
x^{2} 19.480 \quad d f=4 \quad P=0.001 \quad n=784
$$

The null hypothesis is rejected. A chi-square $<9.49$ is required to retain the null hypothesis at the .05 level of significance with 4 degrees of freedom. The data suggest that as years of education increase, anomia decreases.

Hypothesis 23. No significant relationship will be found between female police officers' socioeconomic status background their degree of anomia. The test for this hypothesis consisted of computing a product-moment correlation coefficient for the socioeconomic status background of the female police officers and their degree of anomia. An $r$ of $-0.173(P=0.000)$ was obtained.

The null hypothesis is rejected. In the opinion of the author, the value of $r$ is of sufficient magnitude to suggest some relationship between the variables (see matrix at Appendix E).

Hypothesis 24 . No significant relationship will be found between female police officers' tenure and their degree of anomia. The test for this hypothesis consisted of 
computing a product-moment correlation coefficient for the length of time female police officers have been employed by the police department and their degree of anomia. An $r$ of $-0.113(P=0.004)$ was obtained. The null hypothesis is retained.

In the opinion of the author, the relationship between these variable is weak, but significant enough to explain a modest relationship between the two variables (see matrix at Appendix E).

Hypothesis 25. No significant relationship will be found between female police officers' marital status and their degree of anomia. The distribution of responses and statistical results are presented in Table XXIII.

TABLE XXIII

MARITAL STATUS AND DEGREE OF ANOMIA BY NUMBER AND PERCENT

\begin{tabular}{|c|c|c|c|c|c|c|}
\hline \multirow{3}{*}{ Anomia } & \multicolumn{5}{|c|}{ Marital Status } & \multirow[b]{2}{*}{ Total } \\
\hline & Single & Divorced & Married & Orher & $\begin{array}{l}\text { Spouse in } \mathrm{CJ} \\
\text { System }\end{array}$ & \\
\hline & $\begin{array}{l}\text { Frequency } \\
\text { (percent) }\end{array}$ & $\begin{array}{l}\text { Frequency } \\
\text { (percent) }\end{array}$ & $\begin{array}{l}\text { Frequency } \\
\text { (percent) }\end{array}$ & $\begin{array}{l}\text { Frequency } \\
\text { (percent) }\end{array}$ & $\begin{array}{l}\text { Frequency } \\
\text { (percent) }\end{array}$ & $\begin{array}{l}\text { Frequency } \\
\text { (percent) }\end{array}$ \\
\hline High & $\begin{array}{c}143 \\
(52.96)\end{array}$ & $\begin{array}{c}100 \\
(60.98)\end{array}$ & $\begin{array}{c}53 \\
(41.09)\end{array}$ & $\begin{array}{c}14 \\
(50.00)\end{array}$ & $\begin{array}{c}78 \\
(+0.41)\end{array}$ & $\begin{array}{c}388 \\
(49.49)\end{array}$ \\
\hline Low & $\begin{array}{c}127 \\
(47.04)\end{array}$ & $\begin{array}{c}64 \\
(39.02)\end{array}$ & $\begin{array}{c}76 \\
(98.91)\end{array}$ & $\begin{array}{c}14 \\
(50.00)\end{array}$ & $\begin{array}{c}115 \\
(59.59)\end{array}$ & $\begin{array}{c}390 \\
(50.51) \\
\end{array}$ \\
\hline TOTAL & $\begin{array}{c}270 \\
(100.00)\end{array}$ & $\begin{array}{c}164 \\
(100.00)\end{array}$ & $\begin{array}{c}129 \\
(100.00)\end{array}$ & $\begin{array}{c}28 \\
(100.00)\end{array}$ & $\begin{array}{c}193 \\
(100.00)\end{array}$ & $\begin{array}{c}784 \\
(100.00)\end{array}$ \\
\hline
\end{tabular}

$$
x^{2} 19.965 \quad d f=4 \quad P=0.001 \quad n=784
$$

The null hypothesis is rejected. A chi-square of $<9.49$ is required to retain the null hypothesis at the .05 level of significance with 4 degrees of freedom. The data suggest that single and divorced female police officers are high in anomia, while married 
officers, especially those whose spouse is also employed in the criminal justice system, reflect generally lower anomia scores.

Hypothesis 26. No significant relationship will be found between the type of work female police officers perform and their degree of anomia. The distribution of responses and statistical results are presented in Table XXIV.

\section{TABLE XXIV}

TYPE OF WORK AND DEGREE OF ANOMIA BY NUMBER AND PERCENT

\begin{tabular}{|c|c|c|c|c|c|c|}
\hline \multirow{3}{*}{ Anomia } & \multicolumn{5}{|c|}{ Type of Work } & \multirow[b]{2}{*}{ Total } \\
\hline & $\begin{array}{l}\text { "Protect and } \\
\text { Serve" }\end{array}$ & Investigation & Enforcement & $\begin{array}{l}\text { Administra- } \\
\text { tion }\end{array}$ & Other & \\
\hline & $\begin{array}{l}\text { Frequency } \\
\text { (percent) }\end{array}$ & $\begin{array}{l}\text { Frequency } \\
\text { (percent) }\end{array}$ & $\begin{array}{l}\text { Frequency } \\
\text { (percent) }\end{array}$ & $\begin{array}{l}\text { Frequency } \\
\text { (percent) }\end{array}$ & $\begin{array}{l}\text { Frequency } \\
\text { (percent) }\end{array}$ & $\begin{array}{c}\text { Frequency } \\
\text { (percent) }\end{array}$ \\
\hline High & $\begin{array}{c}258 \\
(50.79)\end{array}$ & $\begin{array}{c}31 \\
(44.93)\end{array}$ & $\begin{array}{c}58 \\
(51.33)\end{array}$ & $\begin{array}{c}13 \\
(40.63)\end{array}$ & $\begin{array}{c}7 \\
(31.82)\end{array}$ & $\begin{array}{c}367 \\
(49.33)\end{array}$ \\
\hline Low & $\begin{array}{c}250 \\
(49.21)\end{array}$ & $\begin{array}{c}38 \\
(55.07)\end{array}$ & $\begin{array}{c}55 \\
(48.67)\end{array}$ & $\begin{array}{c}19 \\
(59.38)\end{array}$ & $\begin{array}{c}15 \\
(68.18)\end{array}$ & $\begin{array}{c}377 \\
(50.67)\end{array}$ \\
\hline TOTAL & $\begin{array}{c}508 \\
(100.00)\end{array}$ & $\begin{array}{c}69 \\
(100.00)\end{array}$ & $\begin{array}{c}113 \\
(100.00)\end{array}$ & $\begin{array}{c}32 \\
(100.00)\end{array}$ & $\begin{array}{c}22 \\
(100.00)\end{array}$ & $\begin{array}{c}744 \\
(100.00)\end{array}$ \\
\hline
\end{tabular}

$$
x^{2} 4.816 \quad d f=4 \quad P=0.307 \quad n=744
$$

The null hypothesis is retained. A chi-square of $>9.49$ is required to reject the null hypothesis at the .05 level of significance with 4 degrees of freedom. However, the data reflect that enforcement appears to be the duty associated with the highest degree of anomia.

Hypothesis 27. No significant relationship will be found between female police officers' rank and their degree of anomia. The distribution of responses and statistical results are presented in Table XXV. 
TABLE XXV

\section{RANK AND DEGREE OF ANOMIA BY NUMBER AND PERCENT}

\begin{tabular}{||c|c|c|c|c|c||}
\hline \multirow{3}{*}{ Anomia } & \multicolumn{4}{|c|}{ Rank } & \multirow{2}{*}{ Total } \\
\cline { 2 - 6 } & Officer & $\begin{array}{c}\text { Investigator } \\
\text { (detective/ } \\
\text { agent) }\end{array}$ & $\begin{array}{c}\text { Supervisor } \\
\text { (corporal/ } \\
\text { sergeant) }\end{array}$ & $\begin{array}{c}\text { Staff } \\
\text { (lieutenant } \\
\text { and above) }\end{array}$ & \\
\cline { 2 - 6 } & $\begin{array}{c}\text { Frequency } \\
\text { (percent) }\end{array}$ & $\begin{array}{c}\text { Frequency } \\
\text { (percent) }\end{array}$ & $\begin{array}{c}\text { Frequency } \\
\text { (percent) }\end{array}$ & $\begin{array}{c}\text { Frequency } \\
\text { (percent) }\end{array}$ & $\begin{array}{c}\text { Frequency } \\
\text { (percent) }\end{array}$ \\
\hline \hline High & $\begin{array}{c}285 \\
(54.60)\end{array}$ & $\begin{array}{c}37 \\
(43.02)\end{array}$ & $\begin{array}{c}46 \\
(40.00)\end{array}$ & $\begin{array}{c}12 \\
(26.67)\end{array}$ & $\begin{array}{c}380 \\
(49.48)\end{array}$ \\
\hline Low & $\begin{array}{c}237 \\
(45.40)\end{array}$ & $\begin{array}{c}49 \\
(56.98)\end{array}$ & $\begin{array}{c}69 \\
(60.00)\end{array}$ & $\begin{array}{c}33 \\
(73.33)\end{array}$ & $\begin{array}{c}388 \\
(50.52)\end{array}$ \\
\hline TOTAL & $\begin{array}{c}522 \\
(100.00)\end{array}$ & $\begin{array}{c}86 \\
(100.00)\end{array}$ & $\begin{array}{c}115 \\
(100.00)\end{array}$ & $\begin{array}{c}45 \\
(100.00)\end{array}$ & $(100.00)$ \\
\hline
\end{tabular}

$$
x^{2} 20.407 \quad \text { df }=3 \quad P=0.000 \quad n=768
$$

The null hypothesis is rejected. A chi-square of $<7.815$ is required to retain the null hypothesis at the .05 significance level with 3 degrees of freedom. The data suggest that as female police officers advance in rank, their degrees of anomia decrease.

Hypothesis 28. No significant relationship will be found between the female police officers' college major and their degree of anomia. The distribution of responses and statistical results are found in Table XXVI. 
TABLE XXVI

COLLEGE MAJOR AND DEGREE OF ANOMIA

BY NUMBER AND PERCENT

\begin{tabular}{|c|c|c|c|c|c|c|c|}
\hline \multirow{3}{*}{ Anomia } & \multicolumn{6}{|c|}{ College Major } & \multirow[b]{2}{*}{ Total } \\
\hline & Humanities & $\begin{array}{c}\text { Social } \\
\text { Science }\end{array}$ & Science & $\begin{array}{l}\text { Criminal } \\
\text { Justice }\end{array}$ & Vocational & None & \\
\hline & $\begin{array}{c}\text { Frequency } \\
\text { (percent) }\end{array}$ & $\begin{array}{c}\text { Frequency } \\
\text { (percent) }\end{array}$ & $\begin{array}{c}\text { Frequency } \\
\text { (percent) }\end{array}$ & $\begin{array}{c}\text { Frequency } \\
\text { (percent) }\end{array}$ & $\begin{array}{c}\text { Frequency } \\
\text { (percent) }\end{array}$ & $\begin{array}{c}\text { Frequency } \\
\text { (percent) }\end{array}$ & $\begin{array}{l}\text { Frequency } \\
\text { (percent) }\end{array}$ \\
\hline High & $\begin{array}{c}29 \\
(34.94)\end{array}$ & $\begin{array}{c}95 \\
(48.72)\end{array}$ & $\begin{array}{c}33 \\
(63.46)\end{array}$ & $\begin{array}{c}129 \\
(46.24)\end{array}$ & $\begin{array}{c}76 \\
(58.91)\end{array}$ & $\begin{array}{c}15 \\
(68.18)\end{array}$ & $\begin{array}{c}377 \\
(49.61)\end{array}$ \\
\hline Low & $\begin{array}{c}54 \\
(65.06)\end{array}$ & $\begin{array}{c}100 \\
(51.28)\end{array}$ & $\begin{array}{c}19 \\
(36.54)\end{array}$ & $\begin{array}{c}150 \\
(53.76)\end{array}$ & $\begin{array}{c}53 \\
(41.09)\end{array}$ & $\begin{array}{c}7 \\
(31.82)\end{array}$ & $\begin{array}{c}383 \\
(50.39)\end{array}$ \\
\hline TOTAL & $\begin{array}{c}83 \\
(100.00)\end{array}$ & $\begin{array}{c}195 \\
(100.00)\end{array}$ & $\begin{array}{c}52 \\
(100.00)\end{array}$ & $\begin{array}{c}279 \\
(100.00)\end{array}$ & $\begin{array}{c}129 \\
(100.00)\end{array}$ & $\begin{array}{c}22 \\
(100.00)\end{array}$ & $\begin{array}{c}760 \\
(100.00)\end{array}$ \\
\hline
\end{tabular}

The null hypothesis is rejected. A chi-square value $<11.070$ is required to retain the null hypothesis at the .05 level of significance with 5 degrees of freedom. The data suggest that those female police officers whose college experience was in the humanities appear to be lowest in anomia, and those with science majors appear to be highest.

\section{AUTHORITARIANISM}

This section will present the analysis of the relationships between certain background characteristics of female police officers and their degree of authoritarianism. The social characteristic of authoritarianism as subsumed behavior has been attributed to police officers. The evidence is inconclusive as to how and when the characteristics associated with authoritarianism become a part of the police personality, if in fact such a personality exists. Balch (1972) reported, "the evidence . . . by its very inconsistency if 
nothing else, does not indicate the existence of police personality, authoritarian or otherwise" (Terry, 1989, p. 547).

According to Kennedy and Homant (1981), role adoption encompasses the values and goals associated with a role. In the case of police officers, accomplishing their societal role of maintaining order and resolving dispute is believed to be enhanced by their subscription to the organizational characteristics and values of authoritarianism (Niederhoffer, 1967). Weiner and McGinnies (1961) suggested a positive relationship between conformity and authoritarianism, which appears to support the proposition offered by Niederhoffer. Conformity to tradition and strict adherence to authority are the cornerstones upon which the authoritarian personality theory is based (Adorno et al., 1950; Janowitz and Marvick, 1953; Rokeach, 1960).

Researchers have attempted to determine the existence or nonexistence of authoritarianism among police officers. Bayley and Mendelsohn (1968) reported, "we have no evidence to indicate that police officers are particularly authoritarian" (p. 18). On the other hand, Austin, Hale, and Ramsey (1987) suggested, "police work is attractive since it lends itself to meeting the needs of the authoritarian personality" (p. 206).

Researchers have studied sociodemographic characteristics in an effort to answer the authoritarianism question, and those characteristics are employed as the independent variables in this study. Those variables are: religion (Super, 1957; Stewart and Hoult, 1979); length of service and age (Genz and Lester, 1976; Teasley and Wright, 1973); socioeconomic status (Janowitz and Marvick, 1953; Christie and Jahoda, 1954; Srole, 1956; Balch, 1972; Culbertson, 1975; Stewart and Hoult, 1979; Terry, 1989); minorities (Bayley and Mendelsohn, 1968); age (Janowitz and Marvick, 1953; Culbertson, 1975; Carlson and 
Sutton, 1975; Genz and Lester, 1976; Stewart and Hoult, 1979); education (Janowitz and Marvick, 1953; Krug, 1961; Smith et al., 1967 and 1970; Culbertson, 1975; Carlson and Sutton, 1975; Dalley, 1975; Stewart and Hoult, 1979; Austin, Hale, and Ramsey, 1987); gender (Culbertson, 1975; Geffner and Gross, 1984); type of duties (Niederhoffer, 1967; Perlstein, 1971).

The Rokeach ( $D$ or Dogmatism) scale was employed in this analysis of authoritarianism. The scale mean is 35 and the female police officers in this study reflected a mean of 30.814 , indicating that they fell well below the scale mean, or, overall were generally low in authoritarianism. This finding was consistent with Perlstein's (1971) study, but contradicts those reported by Niederhoffer (1967).

\section{Proposition 4}

Female police officers' background characteristics can be expected to be related to their degree of authoritarianism.

Hypothesis 29. No significant relationship will be found between female police officers' age and their degree of authoritarianism. The test for this hypothesis consisted of computing the product-moment correlation coefficient for the two variables.

The null hypothesis is retained. An $r$ of $-0.076(P=0.56)$ was obtained, which indicates the age variable is not very useful in explaining female police officers' degree of authoritarianism.

Hypothesis 30. No significant relationship will be found between female police officers' religion and their degree of authoritarianism. The distribution of responses and statistical results are presented in Table XXVII. 
TABLE XXVII

RELIGION AND DEGREE OF AUTHORITARIANISM

BY NUMBER AND PERCENT

\begin{tabular}{|c|c|c|c|c|}
\hline \multirow[b]{3}{*}{ Authoritarianism } & \multicolumn{3}{|c|}{ Religion } & \multirow[b]{2}{*}{ Total } \\
\hline & Protestant & Catholic & Other & \\
\hline & $\begin{array}{l}\text { Frequency } \\
\text { (percent) }\end{array}$ & $\begin{array}{l}\text { Frequency } \\
\text { (percent) }\end{array}$ & $\begin{array}{l}\text { Frequency } \\
\text { (percent) }\end{array}$ & $\begin{array}{c}\text { Frequency } \\
\text { (percent) }\end{array}$ \\
\hline High & $\begin{array}{c}143 \\
(48.47)\end{array}$ & $\begin{array}{c}199 \\
(55.74)\end{array}$ & $\begin{array}{c}28 \\
(51.85)\end{array}$ & $\begin{array}{c}370 \\
(52.41)\end{array}$ \\
\hline Low & $\begin{array}{c}152 \\
(51.53)\end{array}$ & $\begin{array}{c}158 \\
(44.26)\end{array}$ & $\begin{array}{c}26 \\
(48.15)\end{array}$ & $\begin{array}{c}336 \\
(47.59)\end{array}$ \\
\hline TOTAL & $\begin{array}{c}295 \\
(100.00)\end{array}$ & $\begin{array}{c}357 \\
(100.00)\end{array}$ & $\begin{array}{c}54 \\
(100.00)\end{array}$ & $\begin{array}{c}706 \\
(100.00)\end{array}$ \\
\hline
\end{tabular}

$$
\chi^{2} 3.428 \quad \mathrm{df}=2 \quad \mathrm{P}=0.180 \quad \mathrm{n}=706
$$

The null hypothesis is retained. A chi-square of $>5.99$ is required to reject the null hypothesis at the .05 level of significance with 2 degrees of freedom. The data reflect that Catholics appear to be higher in authoritarianism than Protestants, even though the findings do not achieve the appropriate level of significance.

Hypothesis 31 . No significant relationship will be found between female police officers' race and their degree of authoritarianism. The distribution of responses and statistical results are presented in Table XXVIII. 
TABLE XXVIII

\section{RACE AND DEGREE OF AUTHORITARIANISM} BY NUMBER AND PERCENT

\begin{tabular}{||l|c|c|c|c|c||}
\hline \multirow{2}{*}{ Authoritarianism } & \multicolumn{4}{|c|}{ Race } & \multirow{2}{*}{ Total } \\
\cline { 2 - 6 } & \multicolumn{2}{|c|}{ White } & \multicolumn{2}{c|}{ Women of Color } & $\begin{array}{c}\text { Frequency } \\
\text { (percent) }\end{array}$ \\
\cline { 2 - 6 } & Frequency & Percent & Frequency & Percent & $\begin{array}{c}394 \\
(50.97)\end{array}$ \\
\hline \hline High & 262 & 47.99 & 132 & 58.15 & $\begin{array}{c}379 \\
(49.03)\end{array}$ \\
\hline Low & 284 & 52.01 & 95 & 41.85 & $\begin{array}{c}773 \\
(100.00)\end{array}$ \\
\hline TOTAL & 546 & 100.00 & 227 & 100.00 & \\
\hline
\end{tabular}

$\chi^{2} 6.629 \quad \mathrm{df}=1 \quad \mathrm{P}=0.010 \quad \mathrm{n}=773$

The null hypothesis is rejected. A chi-square of $<3.84$ is required to retain the null hypothesis at the .05 level of significance with 1 degree of freedom. The data reflect that Women of Color are higher in authoritarianism than Whites.

Hypothesis 32. No significant relationship will be found between female police officers' years of education and their degree of authoritarianism. The distribution of responses and statistical results are presented in Table XXIX. 
TABLE XXIX

YEARS OF EDUCATION AND DEGREE OF AUTHORITARIANISM BY NUMBER AND PERCENT

\begin{tabular}{||c|c|c|c|c|c||}
\hline \multirow{3}{*}{ Authoritarianism } & \multicolumn{5}{|c||}{ Years of Education } \\
\cline { 2 - 6 } & $<=13$ & $>13<=14$ & $>14<=15$ & $>15<=16$ & $>16$ \\
\cline { 2 - 7 } & $\begin{array}{c}\text { Frequency } \\
\text { (percent) }\end{array}$ & $\begin{array}{c}\text { Frequency } \\
\text { (percent) }\end{array}$ & $\begin{array}{c}\text { Frequency } \\
\text { (percent) }\end{array}$ & $\begin{array}{c}\text { Frequency } \\
\text { (percent) }\end{array}$ & $\begin{array}{c}\text { Frequency } \\
\text { (percent) }\end{array}$ \\
\hline \hline High & $\begin{array}{c}134 \\
(56.54)\end{array}$ & $\begin{array}{c}103 \\
(52.55)\end{array}$ & $\begin{array}{c}48 \\
(53.93)\end{array}$ & $\begin{array}{c}86 \\
(48.86)\end{array}$ & $\begin{array}{c}29 \\
(33.72)\end{array}$ \\
\hline Low & $\begin{array}{c}103 \\
(43.46)\end{array}$ & $\begin{array}{c}93 \\
(47.45)\end{array}$ & $\begin{array}{c}41 \\
(46.07)\end{array}$ & $\begin{array}{c}90 \\
(51.14)\end{array}$ & $\begin{array}{c}57 \\
(66.28)\end{array}$ \\
\hline TOTAL & $\begin{array}{c}237 \\
(100.00)\end{array}$ & $\begin{array}{c}196 \\
(100.00)\end{array}$ & $\begin{array}{c}89 \\
(100.00)\end{array}$ & $(100.00)$ & $\begin{array}{c}86 \\
(100.00)\end{array}$ \\
\hline
\end{tabular}

The null hypothesis is rejected. A chi-square of $<9.49$ is required to retain the null hypothesis at the .05 level of significance with 4 degrees of freedom. The data reflect that as years of education increase the degree of authoritarianism decreases.

Hypothesis 33. No significant relationship will be found between female police officers' socioeconomic status background and their degree of authoritarianism.

The test for this hypothesis consisted of computing a product-moment correlation coefficient for the socioeconomic status background of the female police officers and their degree of authoritarianism. An $r$ of $-0.053(P=0.188)$ was obtained. The null hypothesis is retained. In the opinion of the author, the value of $r$ is not of sufficient magnitude to suggest that the female police officers' socioeconomic background is related to their degree of authoritarianism.

Hypothesis 34 . No significant relationship will be found between female police officers' tenure and their degree of authoritarianism. 
The test for this hypothesis consisted of computing a product-moment correlation coefficient for the length of time female police officers have been employed by the police department and their degree of authortarianism. An $r$ of $-0.100(P=0.012)$ was obtained. The null hypothesis is retained. In the opinion of the author, the $r$ is of insufficient magnitude to suggest a relationship between these two variables.

Hypothesis 35 . No significant relationship will be found between female police officers' marital status and their degree of authoritarianism. The distribution of responses and statistical results are presented in Table XXX.

TABLE XXX

MARITAL STATUS AND DEGREE OF AUTHORITARIANISM BY NUMBER AND PERCENT

\begin{tabular}{|c|c|c|c|c|c|c|}
\hline \multirow{3}{*}{ Authoritarianism } & \multicolumn{5}{|c|}{ Marital Status } & \multirow[b]{2}{*}{ Total } \\
\hline & Single & Divorced & Married & Other & $\begin{array}{c}\text { Spouse in CJ } \\
\text { System }\end{array}$ & \\
\hline & $\begin{array}{c}\text { Frequency } \\
\text { (percent) }\end{array}$ & $\begin{array}{l}\text { Frequency } \\
\text { (percent) }\end{array}$ & $\begin{array}{c}\text { Frequency } \\
\text { (percent) }\end{array}$ & $\begin{array}{c}\text { Frequency } \\
\text { (percent) }\end{array}$ & $\begin{array}{l}\text { Frequency } \\
\text { (percent) }\end{array}$ & $\begin{array}{l}\text { Frequency } \\
\text { (percent) }\end{array}$ \\
\hline High & $\begin{array}{c}140 \\
(51.85)\end{array}$ & $\begin{array}{c}85 \\
(51.83)\end{array}$ & $\begin{array}{c}66 \\
(51.16)\end{array}$ & $\begin{array}{c}14 \\
(50.00)\end{array}$ & $\begin{array}{c}95 \\
(49.22)\end{array}$ & $\begin{array}{c}400 \\
(51.02)\end{array}$ \\
\hline Low & $\begin{array}{c}130 \\
(48.15)\end{array}$ & $\begin{array}{c}79 \\
(48.17)\end{array}$ & $\begin{array}{c}63 \\
(48.84)\end{array}$ & $\begin{array}{c}14 \\
(50.00)\end{array}$ & $\begin{array}{c}98 \\
(50.78)\end{array}$ & $\begin{array}{c}384 \\
(49.98)\end{array}$ \\
\hline TOTAL & $\begin{array}{c}270 \\
(100.00)\end{array}$ & $\begin{array}{c}164 \\
(100.00)\end{array}$ & $\begin{array}{c}129 \\
(100.00)\end{array}$ & $\begin{array}{c}28 \\
(100.00)\end{array}$ & $\begin{array}{c}193 \\
(100.00)\end{array}$ & $\begin{array}{c}784 \\
(100.00)\end{array}$ \\
\hline
\end{tabular}

$$
x^{2} 0.380 \quad \text { df }=4 \quad P=0.984 \quad n=784
$$

The null hypothesis is retained. A chi-square of $>9.49$ is required to reject the null hypothesis at the .05 level of significance with 4 degrees of freedom. The data reflect that marital status is not a significant variable which can be related to degree of authoritarianism. 
Hypothesis 36. No significant relationship will be found between the type of work female police officers perform and their degree of authoritarianism. The distribution of responses and statistical results are presented in Table XXXI.

\section{TABLE XXXI}

\section{TYPE OF WORK AND DEGREE OF AUTHORITARIANISM BY NUMBER AND PERCENT}

\begin{tabular}{|c|c|c|c|c|c|c|}
\hline \multirow{3}{*}{$\begin{array}{l}\text { Authoritar- } \\
\text { ianism }\end{array}$} & \multicolumn{5}{|c|}{ Type of Work } & \multirow[b]{2}{*}{ Total } \\
\hline & $\begin{array}{c}\text { "Protect and } \\
\text { Serve" }\end{array}$ & Investigation & Enforcement & $\begin{array}{l}\text { Administra- } \\
\text { tion }\end{array}$ & Other & \\
\hline & $\begin{array}{l}\text { Frequency } \\
\text { (percent) }\end{array}$ & $\begin{array}{l}\text { Frequency } \\
\text { (percent) }\end{array}$ & $\begin{array}{l}\text { Frequency } \\
\text { (percent) }\end{array}$ & $\begin{array}{c}\text { Frequency } \\
\text { (percent) }\end{array}$ & $\begin{array}{l}\text { Frequency } \\
\text { (percent) }\end{array}$ & $\begin{array}{l}\text { Frequency } \\
\text { (percent) }\end{array}$ \\
\hline High & $\begin{array}{c}269 \\
(52.95)\end{array}$ & $\begin{array}{c}30 \\
(43.48)\end{array}$ & $\begin{array}{c}58 \\
(51.33)\end{array}$ & $\begin{array}{c}16 \\
(50.00)\end{array}$ & $\begin{array}{c}4 \\
(18.18)\end{array}$ & $\begin{array}{c}377 \\
(50.67)\end{array}$ \\
\hline Low & $\begin{array}{c}239 \\
(47.05)\end{array}$ & $\begin{array}{c}39 \\
(56.52)\end{array}$ & $\begin{array}{c}55 \\
(48.67)\end{array}$ & $\begin{array}{c}16 \\
(50.00)\end{array}$ & $\begin{array}{c}18 \\
(81.82)\end{array}$ & $\begin{array}{c}367 \\
(49.33)\end{array}$ \\
\hline TOTAL & $\begin{array}{c}508 \\
(100.00)\end{array}$ & $\begin{array}{c}69 \\
(100.00)\end{array}$ & $\begin{array}{c}113 \\
(100.00)\end{array}$ & $\begin{array}{c}32 \\
(100.00)\end{array}$ & $\begin{array}{c}22 \\
(100.00)\end{array}$ & $\begin{array}{c}744 \\
(100.00)\end{array}$ \\
\hline
\end{tabular}

The null hypothesis is rejected. A chi-square of $<9.49$ is required to retain the null hypothesis at the .05 level of significance with 4 degrees of freedom. The data reflect that authoritarianism is higher in those female police officers who perform line duties ("protect and serve" and enforcement) than for those who perform support functions in the police department.

Hypothesis 37 . No significant relationship will be found between the female police officers' rank and their degree of authoritarianism. The distribution of responses and statistical results are presented in Table XXXII. 
TABLE XXXII

\section{RANK AND DEGREE OF AUTHORITARIANISM BY NUMBER AND PERCENT}

\begin{tabular}{||l|c|c|c|c|c||}
\hline \multirow{4}{*}{ Authoritarianism } & \multicolumn{4}{|c|}{ Rank } & \multirow{2}{*}{ Total } \\
\cline { 2 - 6 } & Officer & $\begin{array}{c}\text { Investigator } \\
\text { (detective/ } \\
\text { agent) }\end{array}$ & $\begin{array}{c}\text { Supervisor } \\
\text { (corporal/ } \\
\text { sergeant) }\end{array}$ & $\begin{array}{c}\text { Staff } \\
\text { (lieutenant } \\
\text { and above) }\end{array}$ & \\
\cline { 2 - 6 } & $\begin{array}{c}\text { Frequency } \\
\text { (percent) }\end{array}$ & $\begin{array}{c}\text { Frequency } \\
\text { (percent) }\end{array}$ & $\begin{array}{c}\text { Frequency } \\
\text { (percent) }\end{array}$ & $\begin{array}{c}\text { Frequency } \\
\text { (percent) }\end{array}$ & $\begin{array}{c}\text { Frequency } \\
\text { (percent) }\end{array}$ \\
\hline \hline High & $\begin{array}{c}291 \\
(55.75)\end{array}$ & $\begin{array}{c}52 \\
(45.22)\end{array}$ & $\begin{array}{c}13 \\
(28.89)\end{array}$ & $\begin{array}{c}32 \\
(37.21)\end{array}$ & $\begin{array}{c}388 \\
(50.52)\end{array}$ \\
\hline Low & $\begin{array}{c}231 \\
(44.25)\end{array}$ & $\begin{array}{c}63 \\
(54.78)\end{array}$ & $\begin{array}{c}32 \\
(71.11)\end{array}$ & $\begin{array}{c}54 \\
(62.79)\end{array}$ & $\begin{array}{c}380 \\
(49.48)\end{array}$ \\
\hline TOTAL & $\begin{array}{c}522 \\
(100.00)\end{array}$ & $\begin{array}{c}115 \\
(100.00)\end{array}$ & $(100.00)$ & $(100.00)$ & $\begin{array}{c}768 \\
(100.00)\end{array}$ \\
\hline
\end{tabular}

$$
x^{2} 20.407 \quad \text { df }=3 \quad P=0.000 \quad n=768
$$

The null hypothesis is rejected. A chi-square $<7.815$ is required tc retain the null hypothesis at the .05 level of significance with 3 degrees of freedom. The data reflect that those who hold the rank of officer are highest in authoritarianism while first line supervisors (corporal/sergeant) appear to be lowest.

Hypothesis 38. No significant relationship will be found between female police officers' college major and their degree of authoritarianism. The distribution of responses and statistical results are presented in Table XXXIII. 
TABLE XXXIII

COLLEGE MAJOR AND DEGREE OF AUTHORITARIANISM BY NUMBER AND PERCENT

\begin{tabular}{|c|c|c|c|c|c|c|c|}
\hline \multirow{3}{*}{$\begin{array}{l}\text { Authori- } \\
\text { tarianism }\end{array}$} & \multicolumn{6}{|c|}{ College Major } & \multirow[b]{2}{*}{ Total } \\
\hline & Humanities & $\begin{array}{l}\text { Social } \\
\text { Science }\end{array}$ & Science & $\begin{array}{l}\text { Criminal } \\
\text { Justice }\end{array}$ & Vocational & None & \\
\hline & $\begin{array}{l}\text { Frequency } \\
\text { (percent) }\end{array}$ & $\begin{array}{l}\text { Frequency } \\
\text { (percent) }\end{array}$ & $\begin{array}{c}\text { Frequency } \\
\text { (percent) }\end{array}$ & $\begin{array}{c}\text { Frequency } \\
\text { (percent) }\end{array}$ & $\begin{array}{c}\text { Frequency } \\
\text { (percent) }\end{array}$ & $\begin{array}{c}\text { Frequency } \\
\text { (percent) }\end{array}$ & $\begin{array}{c}\text { Frequency } \\
\text { (percent) }\end{array}$ \\
\hline High & $\begin{array}{c}35 \\
(42.17) \\
\end{array}$ & $\begin{array}{c}101 \\
(51.79)\end{array}$ & $\begin{array}{c}31 \\
(59.62)\end{array}$ & $\begin{array}{c}140 \\
(50.18)\end{array}$ & $\begin{array}{c}67 \\
(51.94)\end{array}$ & $\begin{array}{c}13 \\
(59.09)\end{array}$ & $\begin{array}{c}387 \\
(50.92)\end{array}$ \\
\hline Low & $\begin{array}{c}48 \\
(57.83)\end{array}$ & $\begin{array}{c}94 \\
(48.21)\end{array}$ & $\begin{array}{c}21 \\
(+0.38)\end{array}$ & $\begin{array}{c}139 \\
(49.82)\end{array}$ & $\begin{array}{c}62 \\
(48.06)\end{array}$ & $\begin{array}{c}9 \\
(40.91)\end{array}$ & $\begin{array}{c}373 \\
(49.08)\end{array}$ \\
\hline TOTAL & $\begin{array}{c}83 \\
(100.00)\end{array}$ & $\begin{array}{c}195 \\
(100.00)\end{array}$ & $\begin{array}{c}52 \\
(100.00)\end{array}$ & $\begin{array}{c}279 \\
(100.00)\end{array}$ & $\begin{array}{c}129 \\
(100.00)\end{array}$ & $\begin{array}{c}22 \\
(100.00)\end{array}$ & $\begin{array}{c}760 \\
(100.00)\end{array}$ \\
\hline
\end{tabular}

The null hypothesis is retained. A chi-square of $>11.070$ is required to reject the null hypothesis at the .05 level of significance with 5 degrees of freedom.

\section{INTERRELATIONSHIPS AMONG SCALES}

There is significant literature on each of the dependent variables of this study. However, there is little on the relationships among them; which leads to the exploration in this study. It is accepted that the present population is not generally representative, but associations within the population may contribute to an understanding of these variable relationships. Both Niederhoffer (1967) and Perlstein (1971) reported their findings on each major hypothesis. However, only Perlstein reported a relationship among them. He tested for anomia, and job satisfaction and morale and found no relationship. 
Scholars continue to debate the authoritarian issue, as it pertains to police officers. Evidence of the following differing theories can be found throughout the literature: Police officers are non-authoritarian (Bayley and Mendelsohn, 1968; Smith, et al., 1970; Guller, 1972; Dalley, 1975); police officers are authoritarian, which is a socialization process caused by membership (Balch, 1972; Niederhoffer, 1967; Teasley and Wright, 1973; Genz and Lester, 1976); or police officers are predisposed to authoritarianism (Culbertson, 1975; Genz and Lester, 1976;). These differing positions lead the author to examine how different degrees of authoritarianism may be manifested, specifically in terms of anomia, and job satisfaction and morale, and reasons for choosing law enforcement as a profession.

Anomia, because it is an individual psychological condition, suggest a relationship with each of the major hypotheses in this study. Job satisfaction is based upon individual perceptions of work and its environment. The degree of anomia exhibited by police officers could be expected to affect attitudes on job satisfaction and morale, and reasons for choosing law enforcement as a profession. Srole (1956) suggested that anomia may manifest itself through authoritarianism.

Job satisfaction and morale suggest an association with reasons for choosing law enforcement as a profession. The female police officers in this study have stated their reason for choosing the profession; however, the question remains as to whether or not their perceptions of the police officer's role has met their expectations. These expectations may or may not be manifested in their degrees of job satisfaction. 


\section{Proposition 5}

The female police officers' degree of authoritarianism can be expected to be related to their degrees of anomia, job satisfaction and morale, and reason for choosing law enforcement as a profession.

Hypothesis 39. No significant relationship will be found between female police officers' degrees of anomia and authoritarianism. The distribution of responses and statistical results are presented in Table XXXIV.

\section{TABLE XXXIV}

\section{DEGREE OF ANOMIA AND AUTHORITARIANISM BY NUMBER AND PERCENT}

\begin{tabular}{||l|c|c|c|c|c||}
\hline \multirow{2}{*}{ Authoritarianism } & \multicolumn{4}{|c|}{ Anomia } & \multirow{2}{*}{ Total } \\
\cline { 2 - 7 } & \multicolumn{2}{|c|}{ High } & \multicolumn{2}{c|}{ Low } & $\begin{array}{c}\text { Frequency } \\
\text { (percent) }\end{array}$ \\
\cline { 2 - 7 } & Frequency & Percent & Frequency & Percent & $\begin{array}{c}400 \\
(51.02)\end{array}$ \\
\hline \hline High & 248 & 63.92 & 152 & 38.38 & $\begin{array}{c}384 \\
(48.98)\end{array}$ \\
\hline Low & 140 & 36.08 & 244 & 61.52 & $\begin{array}{c}784 \\
(100.00)\end{array}$ \\
\hline TOTAL & 388 & 100.00 & 396 & 100.00 & \\
\hline
\end{tabular}

$$
x^{2} 51.130 \quad \text { df }=1 \quad P=0.000 \quad n=784
$$

The null hypothesis is rejected. A chi-square of $<3.84$ is required to retain the null hypothesis at the 0.5 level of significance with 1 degree of freedom. The data reflect that female police officers high in authoritarianism are high in anomia; and those low in anomia are low in authoritarianism. 
Hypothesis 40 . No significant relationship will be found between female police officers' degree of job satisfaction and morale, and degrees of authoritarianism. The distribution of responses and statistical results are presented in Table XXXV.

\section{TABLE XXXV}

JOB SATISFACTION AND MORALE, AND DEGREE OF AUTHORITARIANISM BY NUMBER AND PERCENT

\begin{tabular}{||l|c|c|c|c|c||}
\hline \multirow{2}{*}{ Authoritarianism } & \multicolumn{4}{|c|}{ Job Satisfaction and Morale } & \multirow{2}{*}{ Total } \\
\cline { 2 - 7 } & \multicolumn{2}{|c|}{ High } & \multicolumn{2}{c||}{ Low } & $\begin{array}{c}\text { Frequency } \\
\text { (percent) }\end{array}$ \\
\cline { 2 - 7 } & Frequency & Percent & Frequency & Percent & $\begin{array}{c}400 \\
(51.02)\end{array}$ \\
\hline High & 192 & 45.82 & 208 & 56.99 & $\begin{array}{c}394 \\
(48.98)\end{array}$ \\
\hline Low & 227 & 54.18 & 157 & 43.01 & $\begin{array}{c}784 \\
(100.00)\end{array}$ \\
\hline TOTAL & 419 & 100.00 & 365 & 100.00 & \\
\hline
\end{tabular}

The null hypothesis is rejected. A chi-square of $<3.84$ is required to retain the null hypothesis at the 0.5 level of significance with 1 degree of freedom. The data reflect that high satisfaction is related to low authoritarianism and low satisfaction is related to high authoritarianism.

Hypothesis 41. No significant relationship will be found between female police officers' reason for choosing law enforcement as a profession and their degree of authoritarianism. The distribution of responses and statistical results are presented in Table XXXVI. 
TABLE XXXVI

\section{REASON FOR CHOOSING LAW ENFORCEMENT AND DEGREE AUTHORITARIANISM BY NUMBER AND PERCENT}

\begin{tabular}{|c|c|c|c|c|c|c|}
\hline \multirow{3}{*}{ Authoritarianism } & \multicolumn{5}{|c|}{ Reason for Choosing Law Enforcement } & \multirow[b]{2}{*}{ Total } \\
\hline & Security & Helping & Excitement & Career Goal & Other & \\
\hline & $\begin{array}{l}\text { Frequency } \\
\text { (percent) }\end{array}$ & $\begin{array}{l}\text { Frequency } \\
\text { (percent) }\end{array}$ & $\begin{array}{l}\text { Frequency } \\
\text { (percent) }\end{array}$ & $\begin{array}{c}\text { Frequency } \\
\text { (percent) }\end{array}$ & $\begin{array}{c}\text { Frequency } \\
\text { (percent) }\end{array}$ & $\begin{array}{l}\text { Frequency } \\
\text { (percent) }\end{array}$ \\
\hline High & $\begin{array}{c}112 \\
(54.37)\end{array}$ & $\begin{array}{c}96 \\
(50.00)\end{array}$ & $\begin{array}{c}84 \\
(45.16)\end{array}$ & $\begin{array}{c}38 \\
(47.50)\end{array}$ & $\begin{array}{c}55 \\
(55.00)\end{array}$ & $\begin{array}{c}385 \\
(50.39)\end{array}$ \\
\hline Low & $\begin{array}{c}94 \\
(45.63)\end{array}$ & $\begin{array}{c}96 \\
(50.00)\end{array}$ & $\begin{array}{c}102 \\
(54.84)\end{array}$ & $\begin{array}{c}42 \\
(52.50)\end{array}$ & $\begin{array}{c}45 \\
(45.00)\end{array}$ & $\begin{array}{c}379 \\
(49.61)\end{array}$ \\
\hline TOTAL & $\begin{array}{c}206 \\
(100.00)\end{array}$ & $\begin{array}{c}192 \\
(100.00)\end{array}$ & $\begin{array}{c}186 \\
(100.00)\end{array}$ & $\begin{array}{c}80 \\
(100.00)\end{array}$ & $\begin{array}{c}100 \\
(100.00)\end{array}$ & $\begin{array}{c}764 \\
(100.00)\end{array}$ \\
\hline
\end{tabular}

The null hypothesis is retained. A chi square value $>9.488$ is required to reject the null hypothesis at the .05 level of significance with 4 degrees of freedom.

\section{Proposition 6}

The female police officers' degree of anomia can be expected to be related to their degree of job satisfaction and morale, and reason for choosing law enforcement as a profession.

Hypothesis 42. No significant relationship will be found between female police officers' degree of anomia and job satisfaction and morale. The distribution and responses and statistical results are presented in Table XXXVII. 
TABLE XXXVII

JOB SATISFACTION AND MORALE, AND DEGREE OF ANOMIA BY NUMBER AND PERCENT

\begin{tabular}{||l|c|c|c|c|c||}
\hline \multirow{2}{*}{} & \multicolumn{4}{|c|}{ Job Satisfaction and Morale } & \multirow{2}{*}{ Total } \\
\cline { 2 - 6 } & \multicolumn{2}{|c|}{ High } & \multicolumn{2}{c|}{ Low } & $\begin{array}{c}\text { Frequency } \\
\text { (percent) }\end{array}$ \\
\cline { 2 - 6 } & Frequency & Percent & Frequency & Percent & $\begin{array}{c}419 \\
(53.44)\end{array}$ \\
\hline \hline High & 178 & 45.88 & 241 & 60.86 & $\begin{array}{c}365 \\
(46.56)\end{array}$ \\
\hline Low & 210 & 54.12 & 155 & 39.14 & $\begin{array}{c}784 \\
(100.00)\end{array}$ \\
\hline TOTAL & 388 & 100.00 & 396 & 100.00 & \\
\hline & & &
\end{tabular}

The null hypothesis is rejected. A chi-square of $<3.84$ with 1 degree of freedom is required to retain the null hypothesis at the .05 level of significance. The data reflect that female police officers who are low in anomia appear to be high in job satisfaction, and if they are high in anomia they also tend to be low in job satisfaction and morale.

Hypothesis 43. No significant relationship will be found between female police officers' degree of anomia and their reason for choosing law enforcement as a profession. The distribution of responses and the statistical results are presented in Table XXXVIII. 
TABLE XXXVIII

REASON FOR CHOOSING LAW ENFORCEMENT AND
DEGREE OF ANOMIA BY NUMBER AND PERCENT

\begin{tabular}{|c|c|c|c|c|c|c|}
\hline \multirow{3}{*}{ Anomia } & \multicolumn{5}{|c|}{ Reason for Choosing Law Enforcement } & \multirow[b]{2}{*}{ Total } \\
\hline & Security & Helping & Excitement & Career Goal & Other & \\
\hline & $\begin{array}{c}\text { Frequency } \\
\text { (percent) }\end{array}$ & $\begin{array}{c}\text { Frequency } \\
\text { (percent) }\end{array}$ & $\begin{array}{c}\text { Frequency } \\
\text { (percent) }\end{array}$ & $\begin{array}{c}\text { Frequency } \\
\text { (percent) }\end{array}$ & $\begin{array}{c}\text { Frequency } \\
\text { (percent) }\end{array}$ & $\begin{array}{r}\text { Frequency } \\
\text { (percent) }\end{array}$ \\
\hline High & $\begin{array}{c}112 \\
(54.37)\end{array}$ & $\begin{array}{c}92 \\
(47.92)\end{array}$ & $\begin{array}{c}83 \\
(44.62)\end{array}$ & $\begin{array}{c}47 \\
(55.00)\end{array}$ & $\begin{array}{c}44 \\
(47.00)\end{array}$ & $\begin{array}{c}378 \\
(49.48)\end{array}$ \\
\hline Low & $\begin{array}{c}94 \\
(45.63)\end{array}$ & $\begin{array}{c}100 \\
(52.08)\end{array}$ & $\begin{array}{c}103 \\
(55.38)\end{array}$ & $\begin{array}{c}36 \\
(45.00)\end{array}$ & $\begin{array}{c}53 \\
(53.00)\end{array}$ & $\begin{array}{c}386 \\
(50.52) \\
\end{array}$ \\
\hline TOTAL & $\begin{array}{c}206 \\
(100.00)\end{array}$ & $\begin{array}{c}192 \\
(100.00)\end{array}$ & $\begin{array}{c}186 \\
(100.00)\end{array}$ & $\begin{array}{c}80 \\
(100.00)\end{array}$ & $\begin{array}{c}100 \\
(100.00)\end{array}$ & $\begin{array}{c}764 \\
(100.00)\end{array}$ \\
\hline
\end{tabular}

The null hypothesis is retained. A chi-square $>9.488$ is required to reject the null hypothesis at the .05 level of significance with 4 degrees of freedom. However, the data reflect that female police officers high in anomia tend to have chosen law enforcement as a profession because of career goal and security reasons. Those officers who are low in anomia tend to have chosen law enforcement for reasons of excitement, helping and other reasons.

\section{Proposition 7}

The female police officers' degree of job satisfaction and morale can be expected to be related to their reason for choosing enforcement as a profession.

Hypothesis 44. No significant relationship will be found between female police officers' degree of job satisfaction and morale and their reason for choosing law 
enforcement as a profession. The distribution of responses and statistical results are presented in Table XXXIX.

TABLE XXXIX

REASON FOR CHOOSING LAW ENFORCEMENT, AND JOB SATISFACTION AND MORALE BY NUMBER AND PERCENT

\begin{tabular}{|c|c|c|c|c|c|c|}
\hline \multirow{3}{*}{$\begin{array}{l}\text { Job Satisfaction and } \\
\text { Morale }\end{array}$} & \multicolumn{5}{|c|}{ Reason for Choosing Law Enforcement } & \multirow[b]{2}{*}{ Total } \\
\hline & Security & Helping & Excitement & Career Goal & Other & \\
\hline & $\begin{array}{l}\text { Frequency } \\
\text { (percent) }\end{array}$ & $\begin{array}{l}\text { Frequency } \\
\text { (percent) }\end{array}$ & $\begin{array}{l}\text { Frequency } \\
\text { (percent) }\end{array}$ & $\begin{array}{l}\text { Frequency } \\
\text { (percent) }\end{array}$ & $\begin{array}{l}\text { Frequency } \\
\text { (percent) }\end{array}$ & $\begin{array}{l}\text { Frequency } \\
\text { (percent) }\end{array}$ \\
\hline High & $\begin{array}{c}104 \\
(50.49)\end{array}$ & $\begin{array}{c}104 \\
(54.17)\end{array}$ & $\begin{array}{c}103 \\
(55.38)\end{array}$ & $\begin{array}{c}40 \\
(50.00)\end{array}$ & $\begin{array}{c}58 \\
(58.00)\end{array}$ & $\begin{array}{c}409 \\
(53.53)\end{array}$ \\
\hline Low & $\begin{array}{c}102 \\
(49.51)\end{array}$ & $\begin{array}{c}88 \\
(45.83)\end{array}$ & $\begin{array}{c}83 \\
(44.62)\end{array}$ & $\begin{array}{c}40 \\
(50.00)\end{array}$ & $\begin{array}{c}42 \\
(42.00)\end{array}$ & $\begin{array}{c}355 \\
(46.47)\end{array}$ \\
\hline TOTAL & $\begin{array}{c}206 \\
(100.00)\end{array}$ & $\begin{array}{c}192 \\
(100.00)\end{array}$ & $\begin{array}{c}186 \\
(100.00)\end{array}$ & $\begin{array}{c}80 \\
(100.00)\end{array}$ & $\begin{array}{c}100 \\
(100.00)\end{array}$ & $\begin{array}{c}764 \\
(100.00)\end{array}$ \\
\hline
\end{tabular}

The null hypothesis is retained. The chi-square value $>9.488$ is required to reject the null hypothesis at the .05 level of significance with 4 degrees of freedom. 


\section{CHAPTER V}

\section{CONCLUSIONS}

\section{LIMITATIONS}

This study analyzed responses from the largest population of American female police officers ever surveyed. Because of the exploratory nature of this research, only descriptive data found within the study population are reported and compared with the earlier findings of the Perlstein (1971) study. Analyses of population similarities or differences among IAWP attendees and departmental respondents revealed no differences. Additionally, respondents whose spouses were employed in the criminal justice system did not appear to be distinct from the general population. The findings have significant policy implications for selection, recruiting, retention, and future research of both male and female police officers. However, conclusions cannot be generalized to larger or different populations for the following reasons:

\section{Geographic}

Females were surveyed from the same police departments selected by Perlstein (1971). However, 6 of the 14 original departments, three of which are located on the West Coast, declined to participate. The populations served by the selected sample were all in excess of 500,000 which does not permit generalization to female police officers in smaller departments serving smaller communities. 
$\underline{\text { Gender }}$

Any attempt to compare the findings of this study of females to findings of other studies about males is fraught with difficulties. The evidence about male police officers has been obtained under the friendly umbrella of a traditional occupational setting for males, which is characterized by machoism and conformity to that environment. Data obtained from females, on the other hand, may possibly be biased toward what they should say because of their token membership in a nontraditional occupation.

\section{$\underline{\text { Representativeness }}$}

The respondents were all self-selected, rather than randomized, because it was the only option which offered the probability of obtaining the sample. The survey questionnaire developed information only about the 784 female police officers in the studied population.

\section{SUMMARY}

\section{Reasons for Choosing Law Enforcement}

Female police officers choose law enforcement as a profession for several reasons. The statistical techniques used to analyze the data preclude reaching any causal explanations. The data suggest, however, different degrees of relationships between the variables tested.

Females who entered the police profession over age 25 appeared to favor security and helping as their reasons. Those under the age of 25 , whose reason was career goal, appeared to be motivated by the perceived excitement of the job. This was the same reason for White females who had a high socioeconomic status background. Those with 
lower socioeconomic backgrounds choose the law enforcement profession for security reasons. It was interesting to note that both socioeconomic levels chose helping as their second reason, a finding consistent with Perlstein (1971). Higher education appears to be related with helping because it was the most prominent choice among those with over 16 years of education.

This study and the Perlstein study were consistent in their finding of security as the primary reason for choosing the law enforcement as a profession. A profile emerged of female police officers choosing security as a reason to enter the police profession. They were from low socioeconomic backgrounds; had 15 years or less education; were divorced, Catholic, Women of Color, and over 25 years of age. The excitement reason profile tended to include women from a high socioeconomic background, who were White, single, and under 22 years of age.

The present findings differ from those reported by Perlstein (1971) regarding education, marital status at time of employment, and race. His data required that the hypotheses concerning race, marital status at time of employment, and education be retained, suggesting no relationship. Findings of the present study found that the hypotheses concerning the same variables were rejected, suggesting a relationship. Both studies agree in finding no relationship for the variable of age at the time of entering the law enforcement profession.

The relationship between reasons for choosing law enforcement as a profession, and the variables of rank and college major were not tested by Perlstein (1971). Both rank and college major variables were found to have a relationship with the reason for choosing law enforcement. Those respondents holding supervisory positions identified 
security as the reason they chose law enforcement as a profession. Those who were at the officer level chose law enforcement for helping and career goal reasons.

College major was found to have a relationship with the respondents' reasons for choosing law enforcement as a profession. Science majors chose the career for security reasons, while excitement was the primary reason for both humanities and criminal justice majors.

\section{Job Satisfaction and Morale}

Most female police officers in both the present and Perlstein's (1971) study appeared to be satisfied with their job. Within the variables used to analyze this characteristic, some differences, however, were suggested.

Married females, regardless of race, and whether they worked in investigations or administration appeared to be highest in job satisfaction. Protestants appeared to be less satisfied with their job than Catholics and others, even though all religious groups were found to be high in satisfaction. Divorced officers reflected the least satisfaction of all the marital status variables, which is consistent with Perlstein (1971). The types of work that female police officers perform which reflected the highest degrees of satisfaction were investigations and administration.

Tenure $(r=-0.015, P=0.712)$ indicated a negative correlation with job satisfaction. This finding was consistent with Perlstein's (1971) and suggests that as tenure increases, job satisfaction decreases. However, both studies found that age and satisfaction and morale were positively correlated, which means both variables increase. One might assume that correlations of tenure and age should be consistent with job satisfaction; however, in both study populations they were not. 
Analysis of the college major variable revealed all respondents appeared to score high in job satisfaction. However, within the high groupings it was found that the highest job satisfaction was found to be among humanities majors, and lowest among criminal justice majors.

The rank variable revealed a relationship which shows that the further away from the patrol function the officer is, the higher their satisfaction. The officers, ranked from high to low, were staff (lieutenants and above), investigators and detectives, supervisors (corporals/sergeants), and officers.

All hypotheses in this section of the study had the same test results as were reported by Perlstein (1971). The type of work the female police officers perform and college major, were not tested by Perlstein.

\section{Anomia}

Overall, the findings of this part of the study conflicted with Perlstein (1971), who reported his sample was low in anomia. This study, however, found the respondents to be high in anomia. In both studies, no relationship was found with the religion variable. Even though these studies agreed on statistical findings, differences in relationships were noted. Perlstein's data reflected that Protestants appeared to be low in anomia, while Catholics were high. In this study the opposite tendencies were observed.

For two variables, years of education and marital status, both studies were in agreement; that they had a relationship with anomia. Years of education appears to be inversely related to anomia, for as education increased anomia decreased. Of all marital status categories, those who were divorced appeared to be highest in anomia. The lowest 
level of anomia was found to be among those female police officers whose spouse was also employed in the criminal justice system.

The present study found opposite results from Perlstein's (1971) findings on the race variable. He reported no relationship between race and anomia. This study found a significant relationship; Women of Color appeared to be high in anomia, but White women were low.

The variables age $(r=-0.143, P=0.000)$, socioeconomic status $(r=-0.173, P=$ $0.000)$, and tenure $(r=-0.113, P=0.004)$ were found to have a weak relationship with anomia in this study, which differs from Perlstein (1971). In this study, the absolute values for these variables was slightly higher, but associated with their achieved levels of significance ( $\mathrm{P}$ values) they were deemed to have significance, albeit small. Of note is the fact that each of the correlation coefficients in these analyses had a negative value. This suggests that as tenure, age, and socioeconomic status increase, anomia scores decrease. Perlstein only reported a negative correlation on the variable of socioeconomic status.

The type of work female police officers perform in their department, their college major, and their rank were not studied by Perlstein (1971). In the present study, the type of work did not have a relationship with anomia. Rank and college major, however, were both found to have a relationship with anomia. Overall, within these variables, it was found that the respondents were low in anomia. However, it appeared that the higher the officer's rank the lower their degrees of anomia would be. The relationship with college major found that those with science majors were highest in anomia, and those majoring in humanities were lowest. 
Female police officers who reported high degrees of anomia tended to be Protestant, Women of Color, have less than 13 years of education, have a college background in the sciences, and whose duties included protect and serve and enforcement.

Respondents who were lower in anomia were likely to be White, married to a spouse in the criminal justice system, Catholic, with more than 15 years of education, performing duties in investigations and administration, and have a college background in the humanities.

\section{Authoritarianism}

Perlstein (1971) used the Adorno (F) scale for his analysis of authoritarianism. This study, as previously reported, used the Rokeach (D) scale. For that reason only general comparisons of results can be made. Overall, both studies found that female police officers were low in authoritarianism.

Analyses of the authoritarianism scores revealed that the variables which achieved statistical significance were race, years of education, type of work, and rank. Women of Color were higher in authoritarianism than White women, which is consistent with the findings reported by Perlstein (1971). Also, as respondents' years of education increased, their degree of authoritarianism decreased. The type of work female police officers did was related to their degree of authoritarianism. Those engaged in patrol or enforcement duties were higher in authoritarianism than those in other categories of work, such as investigations, which appeared to be associated with the lowest level of authoritarianism. Those officers holding corporal or sergeant ranks are suggested by the data to have the lowest degrees of authoritarianism, while those with lower rank have the highest. 
Overall, the data suggested that females with less than 13 years of education who perform the basic police tasks at officer level tend to be authoritarian.

Hypotheses on marital status, religion, and college major were retained, indicating no relationships exist between these independent variables and authoritarianism. Stewart's (1979) suggestion that Catholics tend to be more authoritarian than Protestants was not supported in the present study.

The data reflected that age $(r=-0.076, P=0.56)$, tenure $(r=-0.100, P=$ $0.012)$, and socioeconomic status $(r=-0.053, P=0.188$ ) were all negatively correlated with authoritarianism, indicating that as any of these variable increase, the degree of authoritarianism decreases. A similar relationship for socioeconomic status has been previously reported (Christie and Jahoda, 1954; Srole, 1956; Austin et al., 1987).

\section{DIFFERENCES AMONG DEPENDENT VARIABLES}

Authoritarianism, anomia, job satisfaction and morale, and reason for choosing law enforcement as a profession were the dependent variables used in this research. Each was tested using survey instruments which had been previously determined to accurately measure their associated phenomena. The intent of this section is to evaluate the overall relationships among the dependent variables. However, only general statements about the interrelationships of the dependent variables can be made because of the manner in which each is affected by the independent variables. For instance, the independent variable age is positively related to satisfaction and morale, but negatively related to anomia and authoritarianism. The evidence from this study suggest that authoritarianism and anomia may covary; however, which of them affects in the greater 
degree is unknown. Therefore, making assumptions about interrelationships requires a certain degree of caution. This is due, in part, to the statistical techniques required for categorical type data. Perlstein (1971) did not report on the interrelationships among dependent variables.

Generally, degree of authoritarianism increased concurrently with anomia. Lower authoritarianism and anomia appear to be reflected as higher scores on the Job Satisfaction and Morale Index. The test of authoritarianism and reason for choosing law enforcement as a profession did not achieve statistical significance. However, the data reflected that respondents who chose law enforcement for security reasons appear to be highest in authoritarianism.

There were noteworthy differences in terms of the reasons respondents chose law enforcement as a profession. Those who chose for reasons of security and other reasons appeared to be high in anomia and authoritarianism, and low in job satisfaction and morale. This finding is consistent with overall test results for the individual scales.

The findings of this research are consistent with those reported by Peristein (1971), except for those regarding anomia. The intervening 21 years between the studies, and differing populations, did not alter the overall findings in a significant manner, even though higher degrees of anomia were found. Overall this research appears to have validated Perlstein's (1971) study.

\section{POLICY IMPLICATIONS}

Transition to a new philosophy of policing will require major policy changes in the ways in which police officers are recruited, selected, trained, and managed. The evidence 
from this research suggests that females possess those social psychological characteristics which are most consistent with the success of the new paradigm. The low degree of authoritarianism, the high degree of job satisfaction, and the moderate level of anomia among female police officers make them amenable to the community involvement activities required for successful implementation of community policing concepts.

The qualities possessed by women are consistent with the new paradigm, particularly those characteristics which appear to be most consistent with the necessary involvement of the community in successful community policing. Lunneborg (1990) reported that the women in her study were very concerned about delivering quality service because their clients depended on them. Women bring caring attitudes to the work place which contribute significantly to humanizing the work atmospheres, making it collaborative, empathetic, and egalitarian (Lunneborg, 1990). According to Lunneborg (1990), society is now headed toward the valued female qualities and behaviors and away from aggressiveness and dominance. Female police officers can have an impact on improving the environment of police organizations and the delivery of their services because of their nurturing and cooperative attitudes, as opposed to the violent and competitive nature of their male counterparts.

The implications resulting from this research concern four specific areas of policy: (a) problem-solving or community-oriented policing will require different attitudes about the police service, in general, and female police officers in particular; (b) recruitment; (c) selection; and (d) retention. Each of these areas of policy are interrelated and will impact the way police departments are organized and structured under the new paradigm in policing. 


\section{Community-Oriented Policing}

The new paradigm requires a major philosophical change in the manner in which police services are delivered. The socio-psychological attributes of authoritarianism and anomia, traditionally associated with police officers, are not consistent with meeting the goals of community policing. Under the traditional (paramilitary) model, upward communication and risk taking are discouraged (Franz and Jones, 1987). Communityoriented policing encourages and requires communication in all directions. Therefore, police officers who are high in anomia and authoritarianism will not be comfortable with the new philosophy. Behaviors associated with anomia and authoritarianism (alienation and aloofness) do not allow for the necessary degrees of trust and assimilation required under the new paradigm.

Authoritarianism is characterized by strict obedience to organizational rules. At the same time the evidence suggests that those persons who are high in authoritarianism are also high in anomia, which means that such persons are alienated from those who are perceived not to share their values about conforming behaviors. Police officers who possess authoritarian traits and are anomic, are at a significant disadvantage in a work environment which encourages multi-directional communication and community involvement. The evidence of this study suggested that female police officer's attitudes are conducive to the success of community policing because of their moderate degree of anomia and low level of authoritarianism.

Police organizations will have to be reconfigured. The hierarchical structure currently relied upon for control is not consistent with decision-making freedom. The first step in reconfiguration requires geographical decentralization of authority and 
responsibility. Individual police officers possess the responsibility for making decisions to solve problems in their communities. In order to carry out that responsibility, they must have sufficient authority to implement the collective decisions of their communities. Empowerment of line officers to freelance in order to carry out their responsibility is inconsistent with the traditional organization because it encourages actions which may not be rule-based. Female police officers, because they demonstrate lower levels of anomia and authoritarianism, possess attributes consistent with working with others in a less structured environment. Further, as supported by Lunneborg (1990), women are motivated to become police officers for reasons of "being in service to others" (p. 8).

Police officer's performance in the traditional organization is usually measured, in part, by objective criteria (i.e., number of arrests, number of citations, number of crime clearances, etc). These mechanisms address symptoms rather than solutions to problems. Using this incident orientation approach, individual behavior is the unit of analysis. Under the community policing philosophy, emphasis is directed toward underlying problems rather than single incidents. Performance expectations, based on symptoms, create problems on two levels: the individual and the community.

At the individual level, female police officers in this study reported the lowest levels of job satisfaction when performing enforcement duties. These activities require direct contact with people under the guise of solving a problem, when, in reality, problemsolving is severely inhibited because of failure to identify the true unit of analysis--the underlying difficulty. Enforcement activities, therefore, impact both the officer and citizen because they lack a common understanding of the association between actions and goals. The highest levels of job satisfaction were reported by female police officers who 
were engaged in staff and investigative duties. Because of the nature of those duties, it appeared that these officers were most satisfied when engaged in actual problem-solving.

At the community level, when enforcement is the preferred tool for problemsolving, it loses its value and importance because it does not really solve underlying problems. When incidents recur, community confidence in the police suffers because of the perception that they are ineffective.

The evidence seems clear, based upon the findings of this study, that female police officers possess the social attributes and psychological characteristics necessary for the successful transition from the old (paramilitary) to new (community-oriented) paradigm.

\section{Recruiting}

Efforts toward encouraging women to seek careers in law enforcement are presumably being emphasized. The results of these efforts are mixed, which is evidenced by the slow growth in their employment. Females comprise only 8.3 percent of the total police officer population. This is an under-representation in terms of their numbers in the general population. Police agencies need to evaluate their recruiting policies to ensure that prospective candidates possess the characteristics most consistent with successful achievement of community policing concepts.

Some socio-demographic characteristics suggested an association with favorable attitudes among the female police officers of this study. Education had a positive impact because as years of school increased, degrees of authoritarianism and anomia decreased, and job satisfaction and morale increased. This is a very significant finding because conventional wisdom allows recruitment of persons who only possess a high school GED or equivalent. Lower education standards may enlarge the pool of candidates; however, 
those less-educated persons may also have a lower ability to function in a less structured environment. As previously reported, there is evidence that female police officers have more years of education than their male colleagues. If, as the present evidence suggests, higher levels of education reduce incidence of anomia and authoritarianism, it follows that higher education standards should be emphasized in the recruitment process.

Community policing requires police officers to become directly involved in their community. One of the attributes of the anomic authoritarian is psychological separation from those who disagree with their beliefs about conformity to social rules. The female police officers of this study were not high in authoritarianism and were only moderately anomic, suggesting that females are more amendable than males to community integration--an essential ingredient for success of community policing.

\section{$\underline{\text { Selection }}$}

The selection process of police officers is long and detailed. Each step is, presumably, designed to ensure that the best possible candidate is ultimately offered employment. However, because of the absence of standards for success, candidates appear to be eliminated if they are perceived to possess characteristics associated with the perceived potential for failure. The result of this is a process which reinforces the homogeneity of the agency/profession. Skolnick (1966) suggests that similarity, routine, and predictable behaviors are characteristic of paramilitary structures. The primary concern in this regard is that there seems to be limited consensus as to the behavior and traits of the ideal police officer (Hogan, 1971; Meier, Farmer, and Maxwell, 1987).

The methods used by police agencies to select candidates are of major policy importance. Community policing is characterized by police officers engaged with their 
communities for the purpose of solving problems. Many of these problems need innovative and creative solutions which require that predictable behaviors be set aside. Candidates who evidence characteristics suggesting authoritarianism or anomia need very close scrutiny before they are offered employment. The female police officers of this study exhibited characteristics associated with problem-solving skills. They were low in authoritarianism which indicates less rigid behaviors and a more open mind which enables them to look at a problem with a more encompassing view. Because the studied female police officers were only moderately anomic, they are more apt to be able to integrate with citizens who express concern about specific problems. The selection process must adopt problem-solving exercises. It is important, at this stage, to determine if candidates possess the skills necessary in community policing (i.e., problem-solving and ability to work in group settings).

The study did not address the physical abilities of the respondents. However, comment is warranted in light of the fact that this phase of the selection process appears to carry significant weight. Emphasis on physical ability, as evaluated by demonstrating upper body strength, should either be eliminated at the entry level or emphasized throughout an officer's career. If candidates are required to demonstrate certain abilities to gain employment, it should follow that maintaining these skills, as a condition of employment, must also be required. Otherwise, requiring the candidate to achieve a certain level as a condition of employment, only to disregard that requirement after employment serves no purpose and lends to continued discriminatory practices against women. 
There is an absence of data as to those characteristics necessary for success as a police officer. Historically, the MMPI and other psychometric measures have been employed to determine acceptable standards, without having established a police officer baseline. The subjective data which have been developed over time need to be reevaluated for relevancy. Rhead, Abrams, Trosman, and Margolis (1968) reported that certain traits considered to be normal for police officers are otherwise deemed to be pathological if manifested by the general public. It seems clear that pathological psychological characteristics should be considered inappropriate, especially when exhibited by police officers.

One aspect of the selection process is the interviewing of candidates by a selection board comprised of police officers. In this process, candidates are subjectively evaluated by persons whose perception of success is based on traditional organizational concepts. The process does not require candidates to demonstrate specific knowledge of police work, rather, that they demonstrate the cosmetic abilities to speak clearly and to convey the proper physical presence. In other words, they must demonstrate a willingness to orally and physically display authoritarian characteristics. This research found that females were not authoritarian, and such a presence appears to be inconsistent with the desired attributes under the new paradigm.

The author suggests that a more relevant process would be to involve the candidates in problem-solving exercises. Through this mechanism, candidates could be evaluated on their abilities to solve hypothetical problems as well as their abilities to work in group settings, both of which are directly relevant to expected performance under the new paradigm. 


\section{$\underline{\text { Retention }}$}

Retention of police officers can be directly tied to satisfaction. A police career should offer all officers the ability to achieve their maximum potential. The education level of female officers is higher than male officers; however, the level for both is increasing. The more education officers have, the more they desire to think independently and use the skills developed through their education. The traditional organization does not allow for independent thinking and risk-taking. Police organizations which are characterized by authoritarianism cause a polarization of dominant-submission roles (Chwast, 1965), the result of which stifles creative thought and directly relates to job dissatisfaction, particularly among the educated officers.

This study shows that females possess those characteristics required of community policing. However, their retention is contingent upon the degree to which they are accepted by colleagues, administrators, and their communities. Assimilation of women and minorities into the traditional organization presents an important policy problem.

There is a need for developing mentor programs within police agencies. Those persons who are successful in gaining employment soon discover that access to information gained through informal processes are not available to them. The informal process is enhanced by males through collegial outings where mentorships are developed. It is through the informal networking that interpretation and common understanding of organizational rules are learned (Jacobs, 1987). Differential access to organizational rules places women and minorities at a significant learning/experience disadvantage because they are not "one of the boys." 
The literature on mentors discusses positive helping relationships. Police practitioners use language which describe these relationships in somewhat racial and negative terms. Mentors are labeled as Rabbi or Chinaman, terms which describe persons to whom an officer can go for advice and guidance. To overcome the negative connotations generally attributed to these relationships, older officers will need to reorient those attitudes upon which their selection and success have been based.

The characteristic of authoritarianism, which has often been associated with police officers has not been established. The present research appears to be consistent with other studies, expect for Niederhoffer (1967), in that female police officers are not authoritarian. The goal under the new paradigm, is to foster a cooperative effort between communities and the police, rather than total reliance on police authority to solve problems.

\section{FUTURE RESEARCH}

Advancing knowledge relative to police officers, regardless of gender, is of significant importance in the wake of the new paradigm. Past efforts have developed a sound base for further exploration. However, in the opinion of the author, the time has arrived whereupon definitive statements need to be made about those qualities and characteristics demonstrated by successful police officers. In this regard, the following suggestions for future research are offered:

1. There is a need to determine the actual duties performed by police officers. Researchers have accurately identified the service demands placed on the police. 
However, the manner in which services are delivered is as varied as the number of agencies providing the services.

2. Once it is determined what police officers are required to do, mechanisms need to be defined which can evaluate competency levels. Performance evaluations, in the police service, have been empirically based (i.e., number of arrests or citations). However, solving a problem without an arrest is not considered of equal importance, even though it may be more appropriate. New forms of evaluation need to be found.

3. The physical demands of police work have not been established. Without such evidence, employment standards based upon exhibiting strength cannot be justified. The minimum physical standards need to be identified, both for entry level and continued employment. Once established they should be required at both levels.

4. The research is rather clear as to which personality characteristics are associated with unsatisfactory performance by police officers, i.e., low written test scores (what is low?). The evidence is not clear as to the personality characteristics associated with success. The current selection procedure appears to be more of a process of elimination. Studies of successful police officers' personality characteristics are essential to future selection processes.

5. The overall police employment testing procedure needs further study. It does not appear to be based upon the skills necessary in the current era of policing. Testing mechanisms to evaluate officers' problem-solving skills need to be determined and implemented.

6. The structure under which the police are organized is based upon needs for control, conformity, and predictability. The new paradigm for policing is based upon 
control by constituents, conforming to community-determined standards and employing unpredictable solutions to problems. There is a need for developing an organizational structure consistent with transferring authority and responsibility to the lowest possible level. The commonly used term "flattening out" the bureaucracy needs definition and recommendation of ways to implement the concept.

7. Females are competent and an important element of the police profession. Recommendations as to future research do not necessarily need to be directed toward identifying abilities, but rather toward how to help them gain respect for their proven competency.

8. The available evidence suggests that females may possess those qualities which are most consistent with the problem-solving approach of community policing. Those important characteristics need to become a part of the police personality. Curriculum for in-service training programs need to be developed which have the potential of reorienting the authoritarian behaviors of all police officers.

9. The present research suggests that those officers whose college backgrounds were in the humanities appear to be more satisfied, less authoritarian and less anomic. There appears to be a need to look closely at administration of justice programs with a view toward requiring more courses in the humanities for their students.

10. The most important recommendation for future research deals with how to share scholarly research with police administrators. Important information which is usually only published in scholarly journals needs also to be disseminated in the professional publications most widely read by police practitioners. 


\section{REFERENCES}

Adorno, T. W., E. Frenkel-Brunswik, D. J. Levinson, and R. N. Sanford. 1950. The Authoritarian Personality. New York: Harper and Brothers.

Almquist, E. M., and S. Angrist. 1970. "Career Salience and Atypicality of Occupational Choice Among College Women." Joumal of Marriage and the Family 32: 242-249.

Andrisani, P. J. 1978. "Job Satisfaction among Working Women." Signs 3(3): 588-607.

Anderson, R. 1978. "Motive to Avoid Success: A Profile." Sex Roles 4: 239-248.

Armat, V. 1981. "Policewomen in Action." In G. Henderson, ed., Police Human Relations, pp. 270-284. Springfield, IL: Charles C. Thomas.

Ash, P. 1954. "The SRA Employee Inventory--A Statistical Analysis." Personnel Psychology 7: 337-361.

Austin, T. L., D. C. Hale, and L. J. Ramsey. 1987. "The Effect of Layoff on Police Authoritarianism." Criminal Justice and Behavior 14(2): 194-210.

Astrand, P. O. 1956. "Human Physical Fitness with Special Reference to Sex and Age." Psysiological Review 36: 307-335.

Auten, J. H. 1985. "The Paramilitary Model of Police and Police Professionalism." In A. Blumberg and E. Niederhoffer, eds., The Ambivalent Force. New York: Holt Rinehart Pub.

Azen, S. P., H. M. Snibbe, and H. R. A. Montgomery. 1973. "A Longitudinal and Predictive Study of Success and Performance of Law Enforcement Officers." Joumal of Applied Psychology 57(2): 190-192.

Babbie, E. 1989. The Practice of Social Research. California: Wadsworth, Inc.

Baehr, M. E., and R. Renck. 1958. "The Definition and Measurement of Employee Moral." Administrative Science Quanerly 3(2): 157-184.

Balch, R. W. 1972. "The Police Personality: Fact or Fiction." Joumal of Criminal Law. Criminology and Police Science 63: 106-119. 
Balkin, J. 1988. "Why Policemen Don't Like Policewomen." Joumal of Police Science and Administration 16(1): 29-38.

Bartol, C. R. 1982. "Psychological Characteristics of Small-town Police Officers." Joumal of Police Science and Administration 10(1): 58-63.

Bartollas, C., and L. Jaeger. 1988. American Criminal Justice: An Introduction. New York: McMillan Pub. Co.

Bayley, D., and J. Garofalo. 1989. "The Management of Violence by Police Patrol Officers." Criminology 27(1): 1-23.

Bayley, D., and H. Mendelsohn. 1968. Minorities and the Police: Confrontation in America. New York: The Free Press.

Beckman, C. 1975. The Report of the LEAA Task Force on Woman. Washington, DC: Police Foundation.

Bell, D. J. 1982a. "Police Uniforms, Attitudes, and Citizens." Journal of Criminal Justice 10: $45-55$.

----. 1982b. "Policewomen--Myths and Reality." Joumal of Police Science and Administration 10(1): 112-120.

Bennett, R. R., and R. Greenstein. 1975. "The Police Personality: A Test of the Predispositional Model." Joumal of Police Science and Administration 3(4): 439-445.

Bennis, W. G. 1966. Changing Organizations. New York: McGraw-Hill.

Bercal, T. 1970. "Calls for Police Assistance." American Behavioral Scientist 13(5/6): 681-691.

Berdie, R. F. 1943. "Likes, Dislikes and Vocational Interests." Joumal of Applied Psychology 27(2): 180-189

----. 1944. "Factors Related to Vocational Interests." Psychological Bulletin 41(3): 137-157.

Bergmann, B. V. 1986. The Economic Emergence of Women. New York: Basic Books, Inc.

Bernberg, R. E. 1954. "Socio-Psychological Factors in Industrial Morale. III. Relation of Age to Morale." Personnel Psychology 7: 395-399. 
Beutler, L. E., P. D. Nussbaum, and K. E. Meredith. 1988. "Changing Personality Patterns of Police Officers." Professional Psychology: Research and Practice 19(5): 503-507.

Bhatnagar, D. 1988. "Professional Women in Organizations: New Paradigms for Research and Action." Sex Roles 18(5/6): 343-353.

Blanchard-Fields, F., and L. Friedt. 1988. "Age as a Moderator of the Relation Between Three Dimensions of Satisfaction and Sex Role." Sex Roles 18(11/12): 759-767.

Blau, J. R., S. C. Light, and M. Chamlin. 1986. "Individual and Contextual Effects of Stress and Job Satisfaction: A Study of Prison Staff." Work and Occupations 13(1): 131-156.

Block, P., D. Anderson, and P. Gervais. 1973. Policewomen on Patrol: First Report (Major Findings: Volume I). Washington, DC: Police Foundation.

----1974a. Policewomen on Patrol: Final Report. Washington, DC: Police Foundation.

----1974b. Policewomen on Patrol: Final Report. Methodology, Tables and Measurement Instruments. Washington, DC: Police Foundation

Bott, E. 1971. Family and Social Network. London: Travistock Pub.

Bowersox, M. S. 1981. "Women in Corrections: Competence and the Social Responsibility Norm." Criminal Justice and Behavior 8: 491-499.

Brown, L. P. 1989. "Community Policing: A Practical Guide for Police Officials." The Police Chief LVI(7): 72-82.

Burke, R. J., and G. Deszca. 1988. "Career Orientations, Satisfaction and Health Among Police Officers: Some Consequences of Person-Job Misfit." Psychological Reports 62: 639-649.

Burke, W. W. 1982. Organization Development: Principles and Practices. Illinois: Scott Forsman \& Co.

Burlin, F. D. 1976. "Locus of Control and Female Occupational Aspirations." Journal of Counseling Psychology 23: 126-129.

Campbell, W. G., S. Ballou, and C. Slade. 1990. Form and Style. Boston, MA: Houghton Mifflin Co. 
Carison, H. M., and M. S. Sutton. 1975. "The Effects of Different Police Roles on Attitudes and Values." Joumal of Psychology 9: 57-64.

Carpenter, B. N., and S. M. Raza. 1987. "Personality Characteristics of Police Applicants: Comparisons Across Subgroups and with Other Populations." Joumal of Police Science and Administration 15(1): 10-17.

Carter, D., A. Sapp, and D. Stephens. 1989. The State of Police Education: Policy Direction for the 21st Century. Washington, DC: Police Executive Research Forum.

Charles, M. T. 1981. "Performance and Socialization of Female Recruits in the Michigan State Police Training Academy." Journal of Police Science and Administration 9(2): 209-223.

----. 1982. "Women in Policing: The Physical Aspect." Journal of Police Science and Administration 10(2): 194-205.

Charles, N. 1990. "Women and Class--A Problematic Relationship." The Sociological Review 38(1): 43-89.

Christie, R., and M. Jahoda. 1954. Studies in the Scope and Method of "The Authoritarian Personality." Illinois: The Free Press.

Chusmir, H. C. 1983. "Characteristics and Predictive Dimensions of Women Who Make Nontraditional Vocational Choices." Personnel and Guidance Journal 62(1): 43-47.

Chwast, J. 1965. "Value Conflicts in Law Enforcement." Crime and Delinquency 11(2): 151-161.

Cofer, C. N., and M. H. Appley. 1964. Motivation: Theory and Research. New York: John Wiley and Sons.

Collins, J., M. Reardon., and L. K. Waters. 1980. "Occupational Interest and Perceived Personal Success: Effects of Gender, Sex-Role Orientation, and the Sexual Composition of the Occupation." Psychological Report 47: 1155-1159.

Coleman, R. 1978. Social Standing in America. New York: Basic Books, Inc.

Coxon, A., P. Davies., and D. Jones. 1986. Images of Social Stratification: Occupational Structures and Class. California: Sage Publishing Co.

Crawford, J. D. 1978. "Career Development and Career Choice of Pioneer and Traditional Women." Journal of Vocational Behavior 12(2): 129-139. 
Crosby, A. 1979. "The Psychological Examination in Police Selection." Joumal of Police Science and Administration 7(2): 215-229.

Culbertson, R. G. 1975. "Occupational Choice, Corrections or Law Enforcement: A Comparison on the Basis of Dogmatism." Journal of Police Science and Administration 3(1): 95-99.

Cumming, E., I. Cumming, and L. Edell. 1965. "Policemen as Philosopher, Guide and Friend." Social Problems 12(3): 276-286.

Dalley, A. F. 1975. "University v. Non-University Graduated Policemen: A Study of Police Attitudes." Journal of Police Science and Administration 3(4): 95-99.

Davis, J. A. 1984. "Perspectives of Policewomen in Texas and Oklahoma." Joumal of Police Science and Administration 12(4): 395-403.

Deaux, K., and E. Farris. 1977. "Attributing Causes for One's Own Performance: The Effects of Sex, Norms and Outcome." The Journal of Research in Personality 11: 59-72.

Deaux, K., and J. Taynor. 1973. "Evaluation of Male and Female Ability: Bias Works Two Ways." Psychological Reports 32: 261-262.

Deaux, K., and T. Ensmiller. 1974. "Explanations of Successful Performance on Sex-Linked Tasks: What's Skill for the Male is Luck for the Female." Journal of Personality and Social Psychology 29: 80-85.

Deutsch, F. M., and R. T. L. Leong. 1983. "Male Responses to Female Competence." Sex Roles 9(1): 79-91.

Doerfler, M. C., and P. P. Kammer. 1986. "Workaholism, Sex, and Sex Role Stereotyping Among Female Professionals." Sex Roles 14(9/10): 551-560.

Doerner, W. G., J. C. Speir, and B. S. Wright. 1989. "An Analysis of Rater-Ratee Race and Sex Influences Upon Field Training Officer Program Evaluations." Joumal of Criminal Justice 17: 103-114.

Duncan, O. D., P. Hatt, and C. North. 1961. Occupations and Social Status. A. J. Reiss, (Ed). New York: Glencoe Press.

Duncan, O. D., D. Featherman, and B. Duncan. 1972. Socioeconomic Background and Achievement. New York: Seminar Press. 
Enoch, Y. 1988. "Why Are They Different: Background, Occupational Choice, Institutional Selection and Attitudes of Social Work Students." Journal of Social Work Education 24(2): 165-174.

Epstein, C. F. 1978. "Positive Effects of the Multiple Negative: Explaining the Success of Black Professional Women." American Joumal of Sociology, 78: 173-184.

Ewing, D. B. 1971. "The Relations Among Anomie, Dogmatism, and Selected Personal-Social Factors in Asocial Adolescent Boys." Joumal of Social Issues 27(4): 159-169.

Fabianic, D. A. 1979. "Authoritarianism in Criminal Justice Literature." Joumal of Police Science and Administration 7(1): 53-64.

Fagerstrom, D. 1970. "Wider Horizons for Policewomen." Law and Order 18(9): 81-83.

Fairchild, E. S. 1987. "Women Police in Weimar: Professionalism, Politics, and Innovation in Police Organizations." Law and Society Review 21(3): 375-402.

Farr, K. A. 1988. "Dominance Bonding Through the Good Old Boys Sociability Group." Sex Roles 18(5/6): 259-277.

Featherman, D., and C. Stevens. 1982. "A Revised Socio-economic Index of Occupational Status: Analysis of Sex Difference in Attainment." In Essays in Honour of William Hamilton Sewell. New York: Academic Press.

Firth, M. 1982. "Sex Discrimination in Job Opportunities for Women." Sex Roles 8(8): 891-901.

Fitzpatrick, J. L., and R. Silverman. 1989. "Women's Selection of Careers in Engineering: Do Traditional--Nontraditional Differences Still Exist?" Jourmal of Vocational Behavior 34(3): 266-278.

Fordyce, J. K., and R. Weil. 1987. Managing with People. Massachusetts: AddisonWesley Publishing Company.

Franz, V., and D. M. Jones. 1987. "Perceptions of Organizational Performance in Suburban Police Departments: A Critique of the Military Model." Joumal of Police Science and Administration 15(2): 153-161.

Freedman, H., H. Webster, and N. Sanford. 1956. "A Study of Authoritarianism and Psychopathology." The Joumal of Psychology 41: 315-322.

Froehlich, H. P., and L. Wolins. 1960. "Job Satisfaction as Need Satisfaction." Personnel Psychology 13(4): 407-420. 
Frost, Thomas M. 1955. "Selection Methods for Police Recruits." Joumal of Criminal Law, Criminology and Police Science 46(1): 145-155.

Gaines, L. K., P. Costello, and A. Crabtree. 1990. "Police Selection Testing: Balancing Legal Requirements and Employer Needs." American Journal of Police 8(1): 137-152.

Gardner, D. G., and R. Discenza. 1988. "Sex Effects in Evaluating Applicant Qualifications: A Reexamination." Sex Roles 18(5/6): 297-307.

Garmire, B. L. 1982. Local Government Police Management. Washington, DC: The International City Management Association.

Geffner, R., and M. Gross. 1984. "Sex-Role Behavior and Obedience to Authority: A Field Study." Sex Roles 10(11/12): 973-983.

Genz, J. L., and D. Lester. 1976. "Authoritarianism and Policemen as a Function of Experience." Journal of Police Science and Administration 4: 9-13.

Germann, A. C., F. D. Day, and R. J. Gallati. 1970. Introduction to Law Enforcement and Criminal Justice. Illinois: Charles C. Thomas Pub. Co.

Goldstein, H. 1990. Problem-Oriented Policing. New York: McGraw-Hill.

Gottfredson, L. S. 1981. "Circumscription and Compromise: A Developmental Theory of Occupational Aspiration." Journal of Counselling Psychology 28(6): 545-579.

Greenstein, T. N. 1989. "Modifying Beliefs and Behaviors Through Self-Confrontation." Sociological Inquiry 59(4): 396-422.

Grennan, S. A. 1987. "Findings on the Role of Officer Gender in Violent Encounters with Citizens." Joumal of Police Science and Administration 15(1): 78-85.

Guller, I. B. 1972. "Higher Education and Policemen: Attitudinal Differences Between Freshmen and Senior Police College Students." Journal of Criminal Law, Criminology and Police Science 62: 396-401.

Haber, S. 1980. "Cognitive Support for the Career Choice of College Women." Sex Roles 6: 129-138.

Hageman, M. J. 1979. "Who Joins the Force and for What Reasons: An Argument for 'The New Breed."' Journal of Police Science and Administration 7(2): 206-210. 
Hannah, J. S., and S. Kahn. 1989. "The Relationship of Socioeconomic Status and Gender to the Occupational Choices of Grade 12 Students." Joumal of Vocational Behavior 34(2): 161-178.

Hargrave, G. E. 1985. "Using the MMPI to Screen Law Enforcement Applicants: A Study of Reliability and Validity of Clinician's Decisions." Joumal of Police Science and Administration 13(3): 221-224.

Harris, M. 1989. "Personality Moderators of Interpersonal Expectancy Effects: Replication of Harris and Rosenthal (1986)." Journal of Research in Personality 23(4): 381-397.

Harmon, L. W. 1989. "Longitudinal Changes in Women's Career Aspirations: Developmental or Historical?" Journal of Vocational Behavior 35(1): 46-63.

Harrell, W. A., and D. R. Schmitt. 1973. "Effects of a Minimal Audience on Physical Aggression." Psychological Reports 32: 651-657.

Hartman, S. J., R. Griffeth, L. Miller, and A. Kinicki. 1989. "The Impact of Occupation, Performance, and Sex on Sex Role Stereotyping." The Joumal of Social Psychology 128(4): 451-463.

Hazer, J. T., and K. M. Alvares. 1981. "Police Work Values During Organizational Entry and Assimilation." Journal of Applied Psychology 66(1): 12-18.

Helson, R. 1971. "Women Mathematicians and the Creative Personality." Joumal of Consulting and Clinical Psychology 36: 210-220.

Hernandez, Jr., E. 1982. "Females in Law Enforcement: Femininity, Competence, Attraction, and Work Acceptance." Criminal Justice and Behavior 9(1): 13-34.

Herzberg, F. 1971. Work and the Nature of Man. Ohio: The World Pub. Co.

Hiatt, D., and G. E. Hargrave. 1988. "Predicting Job Performance Problems with Psychological Screening." Journal of Police Science and Administration 16(2): 122-125.

Higgins, L. 1951. "Historical Background of Policewomen's Service." Joumal of Criminal Law, Criminology and Police Science 41(6): 822-833.

Hodge, R. W. 1981. "The Measurement of Occupational Status." Social Science Research 10(4): 396-415.

Hogan, R. 1971. "Personality Characteristics of Highly Rated Policemen." Personnel Psychology 24: 679-686. 
Homant, R. J. 1983. "The Impact of Policewomen on Community Attitudes Toward Police." Joumal of Police Science and Administration 11(1): 16-22.

Horne, P. P. 1973. "The Role of Women in Law Enforcement." Police Chief XL(7): 60-63.

-.---. 1975. Women in Law Enforcement. Illinois: Charles C. Thomas Pub.

-..... 1979. "Policewomen: 2000 A.D." Law and Order 27(3): 48-75.

Horowitz, I. L., and S. M. Lipset. 1978. "Equity." In J. Stimpson and A. Stimpson, eds., Sociology: Contemporary Readings. 1983. Illinois: F. E. Peacock Pub. Co.

Hough, K., and B. Allen. 1975. "Is the "Women's Movement" Erasing the Mark of Oppression from the Female Psyche?" The Joumal of Psychology 89: 249-258.

Houser, B. B., and C. Garvey. 1985. "Factors that Affect Nontraditional Vocational Enrollment Among Women." Psychology of Women Quarterly 9: 105-117.

Hulin, C., and P. Smith. 1964. "Sex Differences in Job Satisfaction." Journal of Applied Psychology 48(2): 88-92.

Hunt, J. 1984. "The Development of Rapport Through the Negotiation of Gender in Field Work Among Police." Human Organization 43(4): 283-296.

Inwald, R. E., and E. J. Shusman. 1984. "Personality and Performance: Sex Differences of Law Enforcement Officer Recruits." Joumal of Police Science and Administration 12(3): 339-347.

Jacobs, P. 1987. "How Female Police Officers Cope with a Traditionally Male Position." Sociology and Social Research 72(1): 4-6.

Jagacinski, C. M. 1987. "Androgyny in a Male-Dominated Field: The Relationship of Sex-Typed Traits to Performance and Satisfaction in Engineering." Sex Roles 17(9/10): 529-545.

Jamieson, Katherine M. and Timothy J. Flanagan, eds. 1990. Sourcebook of Criminal Justice Statistics 1989, U. S. Department of Justice, Bureau of Justice Statistics. Washington: GPO.

Janowitz, M., and D. Marvick. 1953. "Authoritarianism and Political Behavior." Public Opinion Quarterly 17(2): 185-201. 
Jenkins, S. R. 1989. "Longitudinal Prediction of Women's Careers: Psychological, Behavioral, and Social-Structural Influences." Joumal of Vocational Behavior 34(2): 204-235.

Jenson, J., E. Hagen, and C. Reddy. 1988. Feminization of the Labor Force. New York: Oxford Press.

Johns, C. J., and A. M. Barclay. 1979. "Female Partners for Male Police: The Effect on Shooting Responses." Criminal Justice and Behavior 6(4): 327-337.

Johnson, E. E. 1983. "Psychological Tests Used in Assessing a Sample of Police and Firefighter Candidates." Joumal of Police Science and Administration 11(4): 430-433.

Johnson, G. H. 1955. "An Instrument for the Measure of Job Satisfaction." Personnel Psychology 8(1): 27-37.

Johnson, W., and L. Terman. 1940. "Some Highlights in the Literature of Psychological Sex Differences Published Since 1920." The Joumal of Psychology 9: 327-336.

Jurik, N. C., G. J. Halemba, M. C. Musheno, and B. V. Boyle. 1987. "Educational Attainment, Job Satisfaction, and the Professionalism of Correctional Officers." Work and Occupations 14(1): 106-125.

Kal, E. F. 1966. "Police Testing." American Joumal of Psychiatry 122: 1064-1065.

Kanter, R. M. 1977a. "Skewed Sex Ratios and Responses to Token Women." American Journal of Sociology 82(5): 965-990.

-.--. 1977b. Men and Women of the Corporation. New York: Basic Books.

Kapalka, G. M., and J. R. Lachenmeyer. 1988. "Sex-Role Flexibility, Locus of Control, and Occupational Status." Sex Roles 19(7/8): 417-425.

Kaplan, A. G., and J. P. Bean. 1976. Beyond Sex-Role Stereotypes: Readings Toward a Psychology of Androgyny. Massachusetts: Little Brown and Company.

Kates, S. L. 1950. "Rorschach Responses, Strong Blank Scales and Job Satisfaction Among Policewomen." Joumal of Applied Psychology 34(4): 249-254.

Kennedy, D. B., and R. J. Homant. 1981. "Nontraditional Role Assumption and the Personality of the Policewoman." Joumal of Police Science and Administration 9(1): $346-355$. 
-...- 1983. "Attitudes of Abused Women Toward Male and Female Police Officers." Criminal Justice and Behavior 10(4): 391-405.

Kephart, W. 1954. "The Integration of Negroes into the Urban Police Force." Joumal of Criminal Law, Criminology and Police Science 45(3): 325-333.

Kidder, L., and C. Judd. 1986. Research Methods in Social Relations. New York: Holt, Rinehart and Winston, Inc.

Kleinmuntz, B. 1967. Personality Measurement: An Introduction. Illinois: The Dorsey Press.

Koenig, E. 1978. "An Overview of Attitudes Toward Women in Law Enforcement." Public Administration Review 38 (May/Jun): 267-275.

Koenig, E. J., and S. Juni. 1981. "Attitudes Toward Policewoman: A Study of Interrelationships and Determinants." Joumal of Police Science and Administration 9(4): 463-474.

Krug, R. E. 1961. "An Analysis of the F Scale: I. Item Factor Analysis." The Joumal of Social Psychology 53: 285-291.

Langworthy, R. H. 1987. "Police Cynicism: What We Know From The Niederhoffer Scale." Joumal of Criminal Justice 15: 17-35.

Larsen, K., R. Elder, M. Bader, and C. Dougard. 1990. "Authoritarianism and Attitudes Toward AIDS Victims." The Joumal of Social Psychology 130(1): 77-80.

Lefkowitz, J. 1975. "Psychological Attributes of Policemen: A Review of Research and Opinion." Joumal of Social Issues 31(1): 3-26.

Lehtinen, M. W. 1976. "Sexism in Police Departments." Trial 12: 52-55.

Lemkau, J. P. 1979. "Personality and Background Characteristics of Women in Male-Dominated Occupations: A Review." Psychology of Women Quarterly 4: 221-240.

....--. 1983. "Women in Male-Dominated Professions: Distinguishing Personality and Background Characteristics." Psychology of Women Quarterly 8: 144-165.

Lester, D. 1982. "Perceived Stress in Police Officers and Belief in Locus of Control." Joumal of General Psychology 107: 157-158.

-.--. 1986. "Attitudes of Police Officers to Rotating Shifts." Psychological Repons 59(3): 1090. 
..-.. 1986. "Subjective Stress and Self-Esteem of Police Officers." Perceptual and Motor Skills 63(3): 1334.

----. 1987. "Correlates of Job Satisfaction in Police Officers." Psychological Reports 60(2): 550.

Lester, D., and D. Sheehan. 1980. "Attitudes of Supervisors Toward Short Police Officers." Psychological Reports 47: 462.

Levenson, H., B. Burford, B. Bonno, and L. Davis. 1975. "Are Women Still Prejudiced Against Women? A Replication and Extension of Goldberg's Study." The Joumal of Psychology 89: 67-71.

Likert, R. 1961. New Patterns in Management. New York: McGraw-Hill.

Lincoln, Y. 1985. Organizational Theory and Inquiry: The Paradigm Revolution. Beverly Hills, CA: Sage Publishing Co., Inc.

Linn, M., B. Linn, S. Stein, and E. Stein. 1989. "Effect of Nursing Home Staff Training on Quality of Patient Survival." Intemational Joumal of Aging and Human Development 28(4): 305-315.

Locke, B., and A. Smith. 1970. "Police Who go to College." In A. Niederhoffer and A. Blumberg (Eds.), The Ambivalent Force. Waltham, MA: Ginn.

Lord, L. K. 1989. "Policewomen." In William G. Bailey, ed., The Encyclopedia of Police Science. New York: Garland Pub. Co., Inc.

Lunneborg, P. 1989. Women Police Officers: Current Career Profile. Illinois: Charles C. Thomas.

-.-. 1990. Women Changing Work. New York: Bergin and Garvey Pub.

Manning, P. K. 1977. Police Work: The Social Organization of Policing. Massachusetts: The MIT Press.

Marsh, S. H. 1962. "Validating the Selection of Deputy Sheriffs." Public Personnel Review 23(1): 41-44.

Martin, S. 1979. "Policewomen and Policewomen: Occupational Role Dilemmas and Choices of Female Officers." Joumal of Police Science and Administration 7(3): 314-322.

-.-.. 1980. Breaking and Entering: Policewomen on Patrol. Berkeley, CA: University of California Press. 
-.--.. 1990. Women On the Move: The Status of Women in Policing. Washington, DC: The Police Foundation.

Mason, R. 1986. Statistical Techniques in Business and Economics. Illinois: Richard D. Irwin, Inc.

Matarazzo, J. D., B. V. Allen, G. Saslow, and A. N. Wiens. 1964. "Characteristics of Successful Policemen and Firemen Applicants." Joumal of Applied Psychology 48(2): 123-133.

Maxwell, G., and J. Cumming. 1988. "Measuring Occupation Aspiration in Research on Sex Differences--An Overview and Analysis of Issues." Joumal of Vocational Behavior 32(1): 60-73.

Mazen, A., and J. Lemkau. 1990. "Personality Profiles of Women in Traditional and Nontraditional Occupations." Journal of Vocational Behavior 37(1): 46-59.

McDill, E. 1961. "Anomie, Authoritarianism, Prejudice, and Socioeconomic Status: An Attempt at Clarification." Social Forces 39(3): 239-245.

McGregor, D. 1960. The Human Side of Enterprise. New York: McGraw-Hill Book Co.

Mcllwee, J. S. 1982. "Work Satisfaction Among Women in Nontraditional Occupations." Work and Occupations 9(3): 299-335.

McNeely, R. R. 1983. "Organization Patterns and Work Satisfaction in a Comprehensive Human Service Agency: An Empirical Test." Human Relations 36(10): 957-972.

Meagher, M. S., and N. A. Yentes. 1986. "Choosing a Career in Policing: A Comparison of Male and Female Perceptions." Joumal of Police Science and Administration 14(4): 320-327.

Meier, D. L., and W. Bell. 1959. "Anomia and Differential Access to the Achievement of Life's Goals." American Sociological Review 24(2): 189-202.

Meier, R. D., R. E. Farmer, and D. Maxwell. 1987. "Psychological Screening of Police Candidates: Current Perspectives." Journal of Police Science and Administration 15(3): 210-215.

Merian, E., D. Stefan, L. Schoenfeld, and J. Kobos. 1980. "Screening of Police Applicants: A 5-Item MMPI Research Index." Psychological Reports 57: 155-158.

Miles, R. E. 1970. "Work, Performance and Satisfaction: A Complimentary Collection." Industrial Relations October 1970: 405-430. 
Miller, D. C. 1940. "Morale of College-Trained Adults." American Sociological Review S(6): 880-889.

Miller, J., and L. Fry. 1976. "Measuring Professionalism in Law Enforcement." Criminology 14(3): 401-412.

Mills, C. J., and W. E. Bohannon. 1980. "Personality Characteristics of Effective State Police Officers." Joumal of Applied Psychology 65: 680-689.

Mills, C. W. 1951. White Collar: The American Middle Classes. New York: Oxford University Press.

Milton, C. 1972. Women in Policing. Washington, DC: Police Foundation.

----. 1978. "The Future or Women in Policing." In A. W. Cohn, ed., The Future of Policing. California: Sage Pub. Co.

Milton, C. H., A. Abramowitz, L. Crites, M. Gates, E. Mintz, and G. Sandler. 1974. Women in Policing: A Manual. Washington, DC: Police Foundation.

Moore, D. P. 1984. "Evaluating In-Role and Out-of-Role Performers." Academy of Management Joumal 27: 603-618.

Moore, H. A. 1985. "Job Satisfaction and Women's Spheres of Work." Sex Roles 13(11/12): 663-677.

Morse, N. C. 1953. Satisfactions in the White-Collar Job. Michigan: University of Michigan Survey Research Center.

Mottaz, C. J. 1987. "Age and Work Satisfaction." Work and Occupations 14(3): 387-409.

Murphy, J. J. 1972. "Current Practices in the Use of Psychological Testing by Police Agencies." Joumal of Criminal Law, Criminology and Police Science 63(4): 570-576.

Neil, C. C. 1988. "Gender as a Moderator of Job Satisfaction: A Multivariate Assessment." Work and Occupations 15(2): 201-219.

Niederhoffer, Arthur. 1967. Behind the Shield: The Police in Urban Society. New York: Doubleday and Doubleday.

O'Donnell, J. A., and D. G. Anderson. 1978. "Factors Influencing Choice of Major and Career of Capable Women." Vocational Guidance Quarterly 26(3): 214-221. 
Owings, Chloe. 1969. Women Police: A Study of the Development and Status of the Women Police Movement. New Jersey: Patterson Smith.

Paterson, D. G., and C. H. Stone. 1942. "Dissatisfaction with Life Work among Adult Workers." Occupations XXI(3): 219-221.

Perlstein, G. R. 1971. An Exploratory Analysis of Certain Characteristics of Policewomen. Michigan: University of Michigan Dissertation Information Service.

Peterson, R. 1973. Task Force Report on Police. Washington, DC: GPO

Plant, W. T. 1960. "Rokeach's Dogmatism Scale as a Measure of General Authoritarianism." Psychological Reports 6: 164.

Poland, J. 1978. "Police Selection Methods and the Prediction of Police Performance." Journal of Police Science and Administration 6(4): 374-393.

Poole, E. D., and M. R. Pogrebin. 1988. "Factors Affecting the Decision to Remain in Policing: A Study of Women Officers." Joumal of Police Science and Administration 16(1): 49-55.

Poole, E. D., and R. M. Regoli. 1979. "Changes in Professional Commitment of Police Recruits: An Exploratory Case Study." Journal of Criminal Justice 7: 243-247.

Powell, G. N. 1988. Women and Men in Management. California: Sage Publishing.

Price, B. R. 1974. "A Study of Leadership Strength of Female Police Executives." Joumal of Police Science and Administration 2(2): 219-226.

Pugh, George. 1985. "The California Psychological Inventory and Police Selection." Joumal of Police Science and Administration 13(2): 172-177.

Raden, D. 1980. "Authoritarianism and Overt Aggression." Psychological Reports 47: 452-454.

Rapoport, T. 1989. "Experimentation and Control: A Conceptual Framework for the Comparative Analysis of Socialization Agencies." Human Relations 42(11): 957-971.

Regoli, R. M. 1976. "An Empirical Assessment of Niederhoffer's Police Cynicism Scale." Journal of Criminal Justice 4(3): 231-241

Regoli, R. M., G. Rivera, Jr., and J. P. Clark. 1988. "Police Cynicism in the United States and Transkei." Sociology and Social Research 72(2): 118-119. 
Reming. G. C. 1988. "Personality Characteristics of Supercops and Habitual Criminals." Joumal of Police Science and Administration 16(3): 163-167.

Rhead, C., A. Abrams, H. Trosman, and P. Margolis. 1968. "The Psychological Assessment of Police Candidates." American Journal of Psychiatry 124: 133-138.

Rhodes, L. 1964. "Anomia, Aspiration, and Status." Social Forces 42(4): 434-440.

Roberg, R. R. 1978. "An Analysis of the Relationships Among Higher Education Belief Systems, and Job Performance on Patrol Officers." Joumal of Police Science and Administration 6(3): 336-344.

Roddenberry, E. 1953. "Achieving Professionalism." Journal of Criminal Law, Criminology and Police Science 44(1): 109-115.

Roe, A. 1956. The Psychology of Occupations. New York: John Wiley and Sons, Inc.

Rokeach, M. 1956. "Political and Religious Dogmatism: An Alternative to the Authoritarian Personality." Psychological Monographs 70(18): 1-43.

Rokeach, M. 1960. The Open and Closed Mind. New York: Basic Books.

Rokeach, M., M. Miller., and J. Snyder. 1971. "The Value Gap Between Police and Policed." Journal of Social Issues 27(2): 155-170.

Romero, G. J., and R. T. Garza. 1986. "Attributions for the Occupational Success/Failure of Ethnic Minority and Nonminority Women." Sex Roles 14(7/8): 445-452.

Rossi, R., J. Wright, and A. Anderson. 1983. Handbook of Survey Research. New York: Academic Press.

Saltiel, J. 1988. "The Wisconsin Model of Status Attainment and the Occupational Choice Process." Work and Occupations 15(3): 334-355.

Sauser, W. I., and C. M. York. 1978. "Sex Differences in Job Satisfaction: A Reexamination." Personnel Psychology 31(3): 537-547.

Saxe, J. J. and Reiser, M. 1976. "A Comparison of Three Police Applicants Groups Using the MMPI." Joumal of Police Science and Administration 4(4): 419-426.

Schultz, D. O., and E. Beckman. 1987. Principles of American Law Enforcement and Criminal Justice. California: Custom Pub. Co. 
Schwarzweller, H. K. 1960. "Values and Occupational Choice." Social Forces 39(2): 126-135.

Segal, S. J. 1961. "A Psychoanalytic Analysis of Personality Factors in Vocational Choice." Journal of Counseling Psychology 8(3): 202-210.

Senna, J. J., and L. J. Siegel. 1987. Introduction to Criminal Justice. Minnesota: West Pub. Co.

Sherman, L. J. 1973. "A Psychological View of Women in Policing." Joumal of Police Science and Administration 1(4): 383-394.

-.-.-. 1975. "Evaluation of Policewomen on Patrol in a Suburban Police Department." Journal of Police Science and Administration 3(4): 434-438.

Shoenfield, L. S., J. C. Kobos, and I. R. Phinney. 1980. "Screening Police Applicants: A Study of Reliability with the MMPI." Psychological Reports 47: 419-425.

Siegfried, W., I. MacFarlane, D. Graham, N. Moore, and P. Young. 1981. "A Reexamination of Sex Differences in Job Preferences." Journal of Vocational Behavior 18(1): 30-42.

Simpson, R. L., and I. H. Simpson. 1960. "Values, Personal Influence, and Occupational Choice." Social Forces 39(2): 116-125.

Skolnick, J. H. 1966. Justice Without Trial. New York: John Wiley and Sons.

Skolnick, J. H., and D. H. Bayley. 1988. Community Policing: Issues and Practices Around the World. Washington, DC: U.S. Department of Justice, National Institute of Justice.

Slater, H. R., and M. Reiser. 1988. "A Comparative Study of Factors Influencing Police Recruitment." Joumal of Police Science and Administration 16(3): 168-176.

Sloan, C. 1954. "Police Professionalism." Journal of Criminal Law, Criminology and Police Science 45(1): 77-79.

Smith, A. B., B. Locke, and A. Fenster. 1970. "Authoritarianism in Policemen Who Are College Graduates and Non-College Police." Journal of Criminal Law, Criminology and Police Science 61(2): 313-315.

Smith, A. B., B. Locke, and W. Walker. 1967. "Authoritarianism in College and Non-College Oriented Police." The Joumal of Criminal Law, Criminology and Police Science 58(1): 128-132. 
-..-. 1968. "Authoritarianism in Police College Students and Non-Police College Students." Joumal of Criminal Law, Criminology and Police Science 59(3): 440-443.

Smith, E. 1982. Breakthrough: Women in Law Enforcement. New York: Walker and Company

South, S. J., W. T. Markham, C. M. Bonjean, and J. Corder. 1987. "Sex Differences in Support for Organizational Advancement." Work and Occupations 14(2): 261-285.

Speizer, J. J. 1981. "Role Models, Mentors, and Sponsors: The Elusive Concepts." Signs: Journal of Women in Culture and Society 6(4): 692-712.

Srole, L. 1956. "Social Integration and Certain Corollaries: An Exploratory Study." American Sociological Review 21(6): 709-716.

Steel, B. S., and N. P. Lovrich. 1987. "Equality and Efficiency Tradeoffs in Affirmative Action--Real or Imagined? The Case of Women in Policing." The Social Science Journal 24(1): 53-70.

Stevens, G. and J. Cho. 1985. "Socioeconomic Indexes and the New 1980 Census Occupational Classification Scheme." Social Science Research 14(2): 142-168.

Stevens, G., and D. Featherman. 1981. "A Revised Socioeconomic Index of Occupational Status." Social Science Research 10(4): 364-395.

Stewart, C., and T. Hoult. 1979. "A Socio-Psychological Theory of the Authoritarian Personality." The American Joumal of Sociology 65(3): 274-279.

Stotland, E., M. Pendleton, and R. Schwartz. 1989. "Police Stress, Time on the Job, and Strain." Journal of Criminal Justice 17: 55-60.

Summers, R. P. 1988. "An Investigation of Sex Differences in Job Satisfaction." Sex Roles 18(11/12): 679-689.

Super, Donald. 1957. The Psychology of Careers. New York: Harper and Brothers.

Sutton, M. S., and H. M. Carlson. 1977. "Attitude and Personality Differences Among Men and Women Studying Police Science." Journal of Social Psychology 102: 161-162.

Talarico, S. M., and C. R. Swanson, Jr. 1982. "Police Perceptions and Job Satisfaction." Work and Occupations 9(1): 59-78. 
Talley, J., L. Hinz, 1990. Performance Prediction of Public Safety and Law Enforcement Personnel: $A$ Study in Race and Gender Differences and MMPI Subscales. Illinois: Charles C. Thomas.

Tangri, S. 1972. "Determinants of Occupational Role Innovation Among College Women." Journal of Social Issues 28: 177-197.

Taubman, B. 1987. Lady Cop. New York: Warner Books.

Taylor, F. W. 1967. The Principles of Scientific Management. New York: W.W. Norton and Co. Inc.

Teasley, C. E. III., and L. Wright. 1973. "The Effects of Training on Police Recruit Attitudes." Joumal of Police Science and Administration 1(2): 241-248.

Teeny, E. 1953. "Women's Work in Law Enforcement." Journal of Criminal Law, Criminology and Police Science 45(2): 239-246.

Teevan, J. J. III., and B. Dolnick. 1973. "Values of the Police: A Reconsideration and Interpretation." Joumal of Police Science and Administration 1(3): 366-369.

Terry, W. C. III. 1989. "Psychological Attributes." In W. G. Bailey, ed., The Encyclopedia of Police Science, pp. 546-552. New York: Garland Pub. Co. Inc.

Trautman, M. 1990. A Study of Law Enforcement: A Comprehensive Study of the World's Greatest, Yet Most Difficult, Profession. Illinois: Charles C. Thomas, Pub.

Triplett, P. E. 1976. "Women in Policing." The Police Chief 43(12): 46-47.

Trodahl, V. C., and F. R. Powell. 1965. "A Short-Term Dogmatism Scale for use in Field Studies." Social Forces 44(2): 211-214.

U.S. Bureau of the Census. 1990. Statistical Abstract of the United States: 1990 (110th Edition). Washington, DC: GPO.

U. S. Department of Justice, Federal Bureau of Investigation. Uniform Crime Reports: 1971, Crime in the United States. Washington, DC: GPO.

-.-.. Uniform Crime Reports: 1972, Crime in the United States. Washington, DC: GPO.

-...-. Uniform Crime Reports: 1989, Crime in the United States. Washington, DC: GPO.

Varca, P. E., G. S. Shaffer, and C. D. McCauley. 1983. "Sex Differences in Job Satisfaction." Academy of Management Joumal 2: 348-353. 
Vroom, V., and F. C. Mann. 1960. "Leader Authoritarianism and Employee Attitudes." Personnel Psychology 13(2): 125-140.

Velde, R. 1976. Two Hundred Years of American Criminal Justice. Washington, DC: GPO.

Waddington, P. A. J. 1982. "Conservatism, Dogmatism, and Authoritarianism in British Police Officers: A Comment." Sociology 16: 592-594.

Washington, B. 1981. "Stress and the Female Officer." In L. Territo and H. J. Vetter, eds., Stress and Police Personnel, pp. 142-147. Boston: Allyn and Bacon.

Washington, B. E. 1974. Deployment of Female Police Officers in the United States. Washington, DC: Police Foundation.

Weaver, C. N. 1978. "Job Satisfaction as a Component of Happiness Among Males and Females." Personnel Psychology 31(4): 831-840.

Weick, K. 1985. "Sources of Order in Unorganized Systems: Themes in Recent Organizational Theory." In Y. Lincoln, ed., Organizational Theory and Inquiry: The Paradigm Revolution. Beverly Hills, CA: Sage Publishing Co., Inc.

Weiner, H., and E. McGinnies. 1961. "Authoritarianism, Conformity, and Confidence in a Perceptual Judgement Situation." The Joumal of Social Psychology 55: 77-84.

Weiner, N. L. 1974. "The Effect of Education on Police Attitudes." Joumal of Criminal Justice 2(4): 317-328.

Weisheit, R. A. 1987. "Women in the State Police: Concerns of Male and Female Officers." Joumal of Police Science and Administration 15(2): 137-144.

Weitz, J. A. 1952. "A Neglected Concept in the Study of Job Satisfaction." Personnel Psychology 5(3): 201-205.

Weldy, W. O. 1976. "Women in Policing--A Positive Step Toward Increased Police Enthusiasm." Police Chief 43(1): 46-47.

Wells, W., D. Weinert, and M. Rubel. 1956. "Conformity Pressure and Authoritarian Personality." Joumal of Psychology 42: 133-136.

Wesley, F., and C. Wesley. 1977. Sex Role Psychology. New York: Human Sciences Press.

Westley, W. A. 1956. "Secrecy and the Police." Social Forces 34(3): 254-257. 
Wexler, J. G. and D. D. Logan. 1983. "Sources of Stress Among Women Police Officers." Joumal of Police Science and Administration 11(1): 46-53.

Wexler, J. G. 1985. "Role Styles of Women Police Officers." Sex Roles 12(7/8): 749-755.

Wharton, A. 1989. "Gender Segregation in Private-Sector, Public-Sector, and Self-Employed Occupations, 1950-1981." Social Science Quarterly 70(4): 923-940.

Whisenand, P. M., and R. F. Ferguson. 1973. The Managing of Police Organizations. Englewood Cliffs, NJ: Prentice Hall Pub.

Wilkinson, Leland. 1988. Systat: The System for Statistics. Illinois: Systat, Inc.

Wilson, J. 1968. Varieties of Police Behavior. Cambridge, MA: Harvard University Press.

Wilt, G. M. and J. D. Bannon. 1976. "Cynicism or Realism: A Critique of Niederhoffer's Research into Police Attitudes." Joumal of Police Science and Administration 4(1): 38-45.

Wolfe, L., and N. Betz. 1981. "Traditionality of Choice and Sex-Role Identification as Moderators of Congruence of Occupational Choice in College Women." Journal of Vocational Behavior 18(1): 43-55.

Wonnacott, T., and R. Wonnacott. 1984. Introductory Statistics for Business and Economics. New York: John Wiley and Sons. 
APPENDIX A

CHARACTERISTICS OF WOMEN IN POLICE SURVEY 


\section{Portland State University}

Purtand. Oregun 473(1)7+17551

\section{CHARACTERISTICS OF WOMEN IN POLICE SURVEY}

You have been selected, as a female police officer. in your department to participate in a study about anomia. job satisfaction/morale and authoritarianism. The study is being conducted in connection with my Ph. $\mathrm{O}$. dissertation. - The attached questionnaire is designed to elicit perceptions and attitudes about your role as a female member of the police profession. The demographic data are employed in association with the statistical analysis of the characteristics being surveyed. The information being gathered will aid in the recruitment and retention of women police officers of the future.

Your participation is important to the integrity of the study. It must be stressed however. that your participation is voluntary and that you may elect at any time not to participate.

It is hoped that you will decide to participate and that you will take the tIme required to complete ine questionnaire and return it promptly. Your answers are anonymous and will be held confidential. In order to insure confidentrality, data from this study will be reported only in aggregate form. Individuat"responses will not be available to your department. To guarantee confidentiality the completed questionnasres are to be relurned directly to Portland State University where the data will be compiled and analyzed. Only I will have access to the completed questionnaires. A copy of the dissertation will be placed in the Portland State University Library. It is hoped that you will contribute to this important research.

The attached questionnaire has been distributed to you by a member of your department. This has been done to expedite delivery of the questionnaire and to preserve your personal privacy in its completion.

It is estimated that it will take about 30 minutes of your time to complete the several sections of the questionnaire. Each questionnaire has been assigned an agency code number in the upper righthand corner of page one. The purpose of the code number is for recording returned questionnaires, by police department. The codes are not assigned to individuals, only their employing agency. To insure anonymity and confidentiality. please do not sign or mark on the completed questionnaire. which could be used to determine your identity.

Please return your completed questionnarre as soon as oossible. Simply place the completed documents into the attached self-addressed, return postage guaranteed envelope. If you have any questions as to the purpose of the study. content of the questionnaire. and the uses to which the data will be used. please contact me.

Thank you for your cooperation and participation in this study.<smiles>CC(C)(C)COC(C)(C)C</smiles>

Harry 0. White, Jr.

Doctoral Candidate

Department of Urban Studies and Planning

School of Urban and Public Affairs

Portland State University

Portland, Oregon 97207

1.503 .725 .4014 


\section{Survey Questionnaire}

\section{Section 1}

1. Age at entry into police work:

2. Marital status at entry into police work: Single $\square$. Divorced $\square$. Married $\square$, Other $\square$

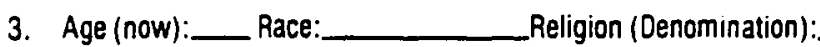

4. Marital status (now): Single $\square$. Married $\square$, Divorced $\square$, Other $\square$

5. If married, does your spouse work in the justice system? Yes $\square$ No $\square$

6. Education:

Compieted High School: Yes $\square$ No $\square$, G.E.D: Yes $\square$ No $\square$ Years of College___. Type of Degree

7. If you have had some college or university education what was your major field of study?

8. Father's occupation:

9. Mother's occupation:

10. Beiore entering the field of law enforcement were you employed in any other occupation? Yes $\square$ No $\square$

11. If you answered YES to question 10, please list your other occupations:

12. Why, in your opinion. did you choose to become a police officer?

13. Do you believe that you will continue to be a police officer for the rest of your employed life? Yes $\square$ NoD

14. What, in your opinion, are your duties as a police officer?

15. Length of time as a police officer:___ Rank:

16. Do you live in the city that you work? Yes $\square$ No $\square$ 


\section{Section 2}

Read each item carefully and mark quickly the phrase that best expresses your feeling about the question.

1. How do you like working for your department?

Strongly like $\square$. Like $\square$. Undecided $\square$. Dislike $\square$. Strongly Dislike $\square$

2. Would you advise a friend to come to work for your department? Definitely Yes $\square$. Yes $\square$. Undecided $\square$. NoL, Detinirely NoD

3. How well do you like the sort of work you are doing? Strongly Like己. Like $\square$, Undecioed $[$. Dislike $\square$. Sirongly Dislike $\square$

4. Does your job give you a chance to do the things you feel you do best? Delinitely Yes $\square$. Yes $\square$, Undecided $D$. No $\square$. Definitely NoD

5. Do you get any feeling of accomplishment from the work you are doing? Defintely YesE. YesL. Undecided $\square$. NoL Definitely NoD

6. How do you feel about your work: does it rate as an important job to you? Very Important $\square$. Important $\square$. Undecided $E$. Unimportant $\square$. Very Unimportant [

7. How well do you think your section compares with other sections in the department in getting the joo cone?

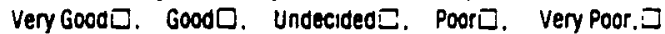

8. How well satisfied are you with your salary?

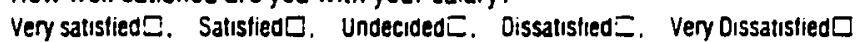

9. How satisfied are you with your chances of getting more pay?

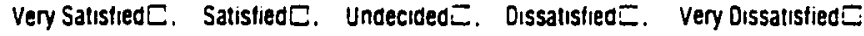

\section{Section 3}

1. In spite of what some people say, the lot of the average person is getting worse. Strongiy agree $\square$. Agree $\square$. Undecided $[$. Oisagree $匚$. Strongly Disagree $\square$

2. It's hardly fair to bring children into the world with the way things look for the future. Strongly AgreeC. Agree $\square$. Undecided C. DisagreeL. Strangly Disagreed

3. Nowadays a person has to live pretty much for today and let tomorrow take care of itself. Strongly Agree $\square$. Agree $\square$. Undecided C. Disagree[. Strongly Disagreed

4. These days a person doesn't really know who she can count on.

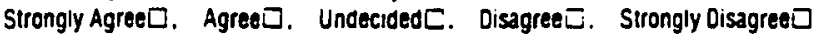

5. There's little use writing to public officials because often they aren't really interested in the problems of the average person.

Strongly Agree $\square$. Agree $\square$. Undecided $\square$. Disagree $\square$. Strongly Disagree $\square$

\section{PLEASE GO TO THE NEXT PAGE}




\section{Section 4}

Read each Item carefully and mark quickly the phrase that best expresses your feeling about the question.

1. In the history of mankind there have probably been just a handful of really great thinkers. Strongly Disagree $\square$. Somewhat Disagree $\square$. Disagree $\square$. Undecided $\square$. Agree $\square$. Somewnat AgreeD. Strongly Agree $\square$

2. There are a number of people I have come to hate because of the things they stand for.

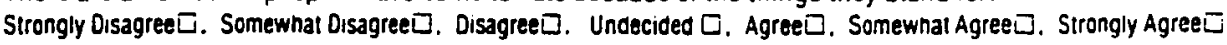

3. A great person who does not believe in some great cause has not really lived.

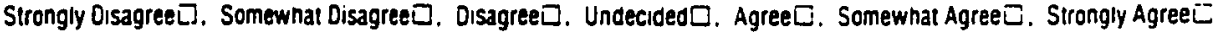

4. It is only when a person devotes themself to an ideal or cause that life becomes meaningful.

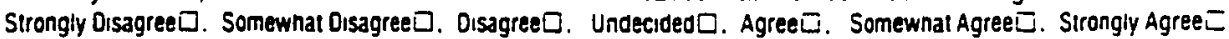

5. Of all the different philosophies which exist in this world there is probably only one which is perfect. Strongly Disagree $\square$. Somewnat Disagree:Z. Disagree $匚$. Undecided $D$. Agree $\square$. Somewnat Agree:- Strongly Agree:-

6. A person who gets enthusiastic about too many causes is likely to be a pretty " wishy-washy" sort of person

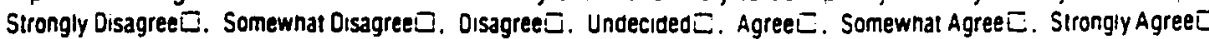

7. To compromise with potitical opponents is dangerous because it usually leads to the betrayal of our own side.

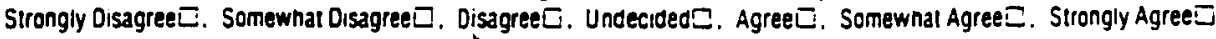

8. When it comes to differences of opinion in religion we must be careful not to compromise with those who believe differently from the way we do.

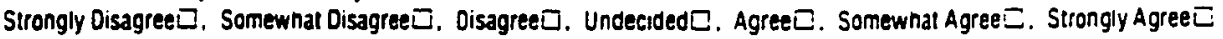

9. In times like these. a person must be pretty selfish if they consider primarily their own happıness.

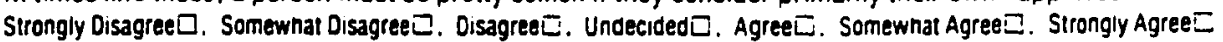

10. To compromise with our political opponents is to be guilty of appeasement.

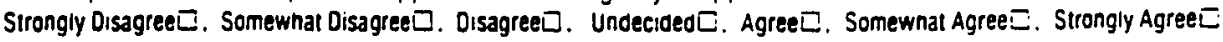

\section{THANK YOU FOR YOUR COOPERATION}

If you experience problems that are the result of your participation in this study, please contact the Chair of the Human Subjects Research Review Committee, Oflice of Grants and Contracts, 303 Cramer Hall, Portland State University, (503) 725-3417. 
APPENDIX B

STATISTICAL SUMMARY 
STATISTICAL SUMMARY

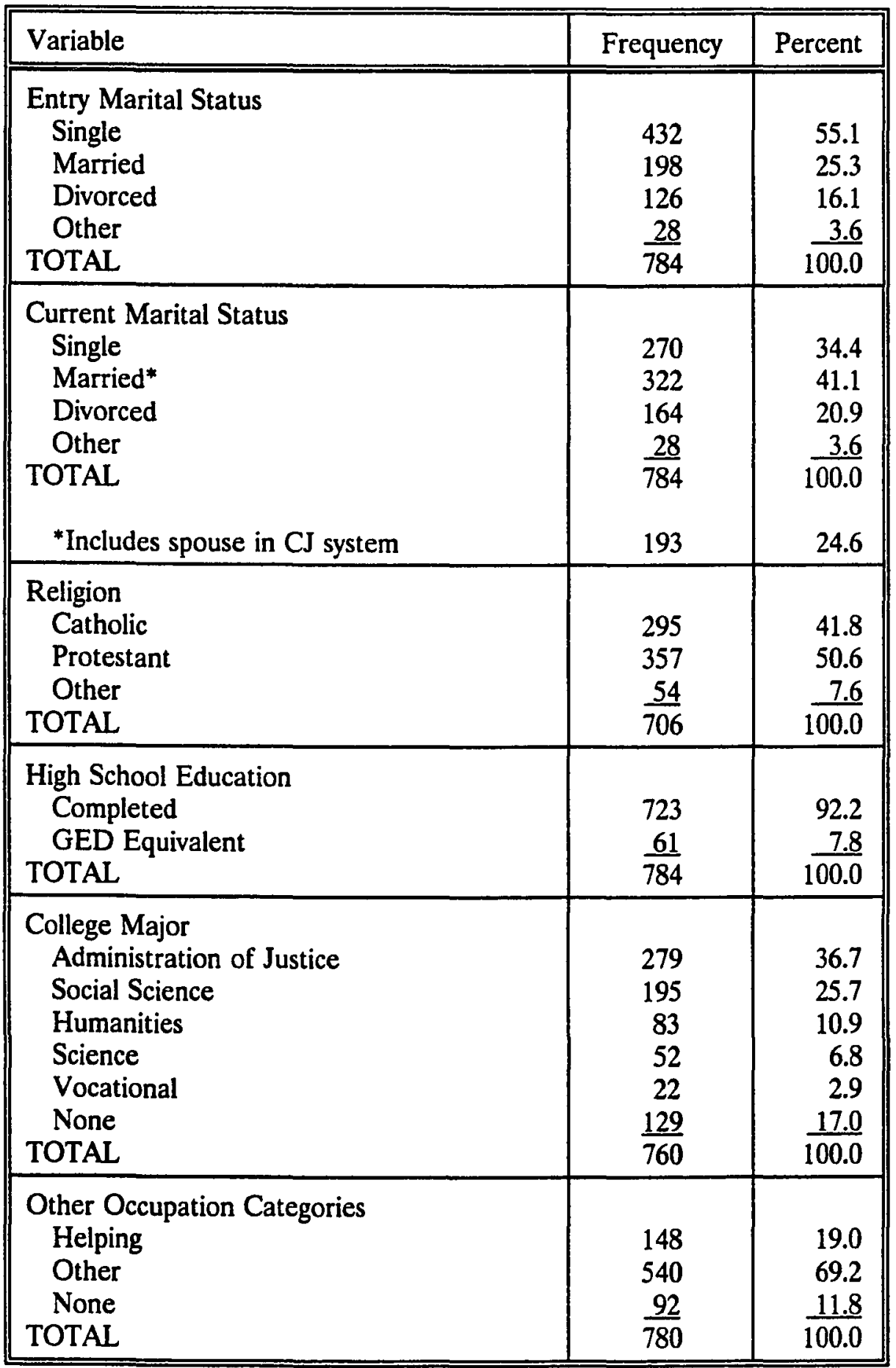


STATISTICAL SUMMARY (Continued)

\begin{tabular}{|c|c|c|}
\hline Variable & Frequency & Percent \\
\hline $\begin{array}{l}\text { Reasons for Choosing Law Enforcement } \\
\text { Security } \\
\text { Helping } \\
\text { Excitement } \\
\text { Other } \\
\text { Career Goal } \\
\text { TOTAL }\end{array}$ & $\begin{array}{r}206 \\
192 \\
186 \\
100 \\
\frac{80}{764} \\
\end{array}$ & $\begin{array}{l}27.0 \\
25.1 \\
24.3 \\
13.1 \\
10.5 \\
100.0\end{array}$ \\
\hline $\begin{array}{l}\text { Type of Work Performed } \\
\text { Protect and Serve } \\
\text { Enforcement } \\
\text { Investigation } \\
\text { Administrative } \\
\text { Other } \\
\text { TOTAL } \\
\end{array}$ & $\begin{array}{r}508 \\
113 \\
69 \\
32 \\
22 \\
744\end{array}$ & $\begin{array}{r}68.3 \\
15.2 \\
9.3 \\
4.3 \\
3.0 \\
100.0\end{array}$ \\
\hline $\begin{array}{l}\text { Rank } \\
\text { Police Officer } \\
\text { Line supervision (corporal/sergeant) } \\
\text { Staff supervision (lieutenants, etc.) } \\
\text { Detectives and investigators }\end{array}$ & $\begin{array}{r}522 \\
115 \\
45 \\
86 \\
768 \\
\end{array}$ & $\begin{array}{r}68.0 \\
15.0 \\
5.9 \\
11.2 \\
100.0\end{array}$ \\
\hline $\begin{array}{l}\text { Years of Education } \\
13 \text { years and less } \\
>13 \text { but }<=14 \text { years } \\
>14 \text { but }<=15 \text { years } \\
>15 \text { but }<=16 \text { years } \\
16 \text { years or more }\end{array}$ & $\begin{array}{r}237 \\
196 \\
89 \\
176 \\
\frac{86}{784}\end{array}$ & $\begin{array}{l}30.2 \\
25.0 \\
11.4 \\
22.4 \\
11.0 \\
100.0\end{array}$ \\
\hline $\begin{array}{l}\text { Race } \\
\text { White } \\
\text { Black } \\
\text { Other (Hispanic, Asian, Native American) }\end{array}$ & $\begin{array}{r}546 \\
195 \\
\frac{34}{784}\end{array}$ & $\begin{array}{r}70.5 \\
25.1 \\
4.4 \\
100.0\end{array}$ \\
\hline
\end{tabular}


APPENDIX C

\section{SUMMARY STATISTICS}




\section{SUMMARY STATISTICS}

\begin{tabular}{|l|c|c|c|c|c|c|c||}
\hline Variable & Number & Minimum & Maximum & Range & Mean & SD & SE \\
\hline \hline Entry Age & 783 & 18 & 41 & 23 & 25.501 & 4.354 & 0.156 \\
\hline Current Age & 779 & 20 & 61 & 41 & 34.032 & 6.478 & 0.232 \\
\hline Length of Service & 780 & 0.1 & 31 & 30.9 & 8.522 & 5.411 & 0.194 \\
\hline Years of Education & 784 & 12 & 21.5 & 9.5 & 14.461 & 3.276 & 1.810 \\
\hline Father's Occupation & 598 & 15.260 & 89.570 & 74.310 & 36.805 & 18.645 & 0.762 \\
\hline Mother's Occupation & 427 & 15.260 & 86.600 & 71.340 & 34.685 & 14.164 & 0.685 \\
\hline Both Occupations & 679 & 15.260 & 89.570 & 74.310 & 39.457 & 17.956 & 0.689 \\
\hline Other Occupations & 662 & 15.710 & 88.420 & 72.710 & 32.669 & 13.265 & 0.516 \\
\hline Anomia & 774 & 5.000 & 25.000 & 20.000 & 13.813 & 3.760 & 0.135 \\
\hline $\begin{array}{l}\text { Satisfaction and } \\
\text { Morale }\end{array}$ & 756 & 13.000 & 45.000 & 32.000 & 34.478 & 5.914 & 0.215 \\
\hline Authoritarianism & 759 & 10.000 & 57.000 & 47.000 & 30.814 & 7.939 & 0.288 \\
\hline
\end{tabular}


APPENDIX D

NONOCCUPATION CATEGORIES BY NUMBER AND PERCENT 


\section{NONOCCUPATION CATEGORIES}

BY NUMBER AND PERCENT

\begin{tabular}{||l|c|c|c|c||}
\hline Category & Father & Mother & Respondent & Total \\
\cline { 2 - 5 } & $\begin{array}{c}\text { Frequency } \\
\text { (percent) }\end{array}$ & $\begin{array}{c}\text { Frequency } \\
\text { (percent) }\end{array}$ & $\begin{array}{c}\text { Frequency } \\
\text { (percent) }\end{array}$ & $\begin{array}{c}\text { Frequency } \\
\text { (percent) }\end{array}$ \\
\hline \hline Deceased & $\begin{array}{c}61 \\
(36.53)\end{array}$ & $\begin{array}{c}39 \\
(11.11)\end{array}$ & 0 & $\begin{array}{c}100 \\
(15.82)\end{array}$ \\
\hline Retired & $\begin{array}{c}45 \\
(27.54)\end{array}$ & $\begin{array}{c}38 \\
(10.83)\end{array}$ & 0 & $\begin{array}{c}83 \\
(13.13)\end{array}$ \\
\hline Homemaker & 0 & $\begin{array}{c}237 \\
(67.52)\end{array}$ & $\begin{array}{c}1 \\
(0.87)\end{array}$ & $\begin{array}{c}238 \\
(37.65)\end{array}$ \\
\hline Unable to Classify* & $\begin{array}{c}35 \\
(20.96)\end{array}$ & $\begin{array}{c}20 \\
(5.70)\end{array}$ & $\begin{array}{c}21 \\
(18.26)\end{array}$ & $\begin{array}{c}76 \\
(12.02)\end{array}$ \\
\hline None & $\begin{array}{c}25 \\
(14.97)\end{array}$ & $\begin{array}{c}17 \\
(4.84)\end{array}$ & $\begin{array}{c}93 \\
(80.87)\end{array}$ & $\begin{array}{c}135 \\
(21.38)\end{array}$ \\
\hline TOTAL & $\begin{array}{c}166 \\
(100.00)\end{array}$ & $\begin{array}{c}351 \\
(100.00)\end{array}$ & $\begin{array}{c}115 \\
(100.00)\end{array}$ & $\begin{array}{c}632 \\
(100.00)\end{array}$ \\
\hline
\end{tabular}

"Some occupations were not listed in the Stevens and Cho index, an example of which is military, without listing any specific type of duties or job title within the military service. 
APPENDIX E

CORRELATION COEFFICIENTS 
CORRELA'TION COEFFICIENTS

\begin{tabular}{|c|c|c|c|c|c|c|}
\hline & Current Age & $\begin{array}{l}\text { Socioeconomic } \\
\text { Background }\end{array}$ & Tenure & Satisfaction & Allomia & Authoritarianisn \\
\hline Current Age & $\begin{array}{c}1.00 \\
(0.000)\end{array}$ & & & & & \\
\hline $\begin{array}{l}\text { Socioeconomic } \\
\text { Background }\end{array}$ & $\begin{array}{c}-0.130 \\
(1.001)\end{array}$ & $\begin{array}{c}1.00) \\
(0.00(1))\end{array}$ & & & & \\
\hline Tenure & $\begin{array}{c}0.756 \\
(0.000)\end{array}$ & $\begin{array}{c}-(0.031 \\
(0.445)\end{array}$ & $\begin{array}{c}1.001 \\
(0.000)\end{array}$ & & & \\
\hline Satisfaction & $\begin{array}{c}0.003 \\
(0.935)\end{array}$ & $\begin{array}{c}0.051 \\
(0.2(1)\end{array}$ & $\begin{array}{c}-0.015 \\
(0.712)\end{array}$ & $\begin{array}{c}1.00 \\
(0.000)\end{array}$ & & \\
\hline Anomia & $\begin{array}{c}-0.143 \\
(0.000)\end{array}$ & $\begin{array}{c}-0.173 \\
(0.000)\end{array}$ & $\begin{array}{c}-0.113 \\
(0.00(1)\end{array}$ & $\begin{array}{c}-0.289 \\
(0.0110)\end{array}$ & $\begin{array}{c}1.00 \\
(0.00(1)\end{array}$ & \\
\hline Authoritarianism & $\begin{array}{r}-0.076 \\
(0.056)\end{array}$ & $\begin{array}{r}-0.053 \\
(0.188)\end{array}$ & $\begin{array}{c}-0.100 \\
(0.012)\end{array}$ & $\begin{array}{r}-0.214 \\
(11.00(1))\end{array}$ & $\begin{array}{c}0.379 \\
(0.00(0)\end{array}$ & $\begin{array}{c}1.00 \\
(0.000)\end{array}$ \\
\hline
\end{tabular}

$P$ value in parenthesis. 